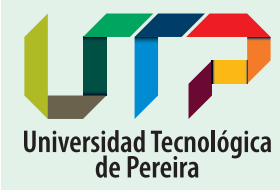

Facultad

de Ciencias de la Educación

\title{
Conexión Emoción - Razón En busca de la unidad perdida en el plano educativo
}
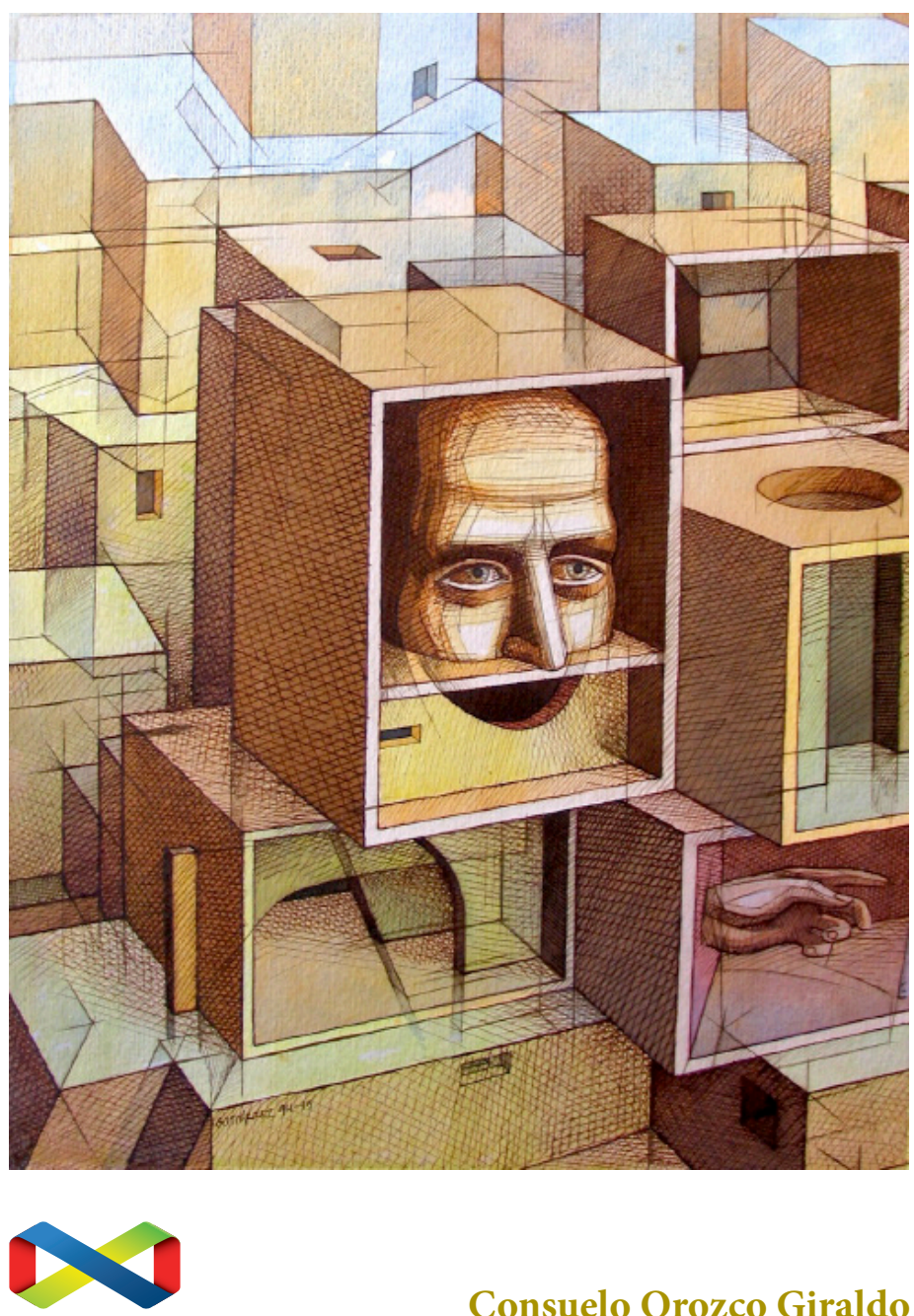

Editorial UTP

Consuelo Orozco Giraldo 


\section{Conexión Emoción - Razón}

\section{En busca de la unidad perdida}

en el plano educativo

Consuelo Orozco Giraldo

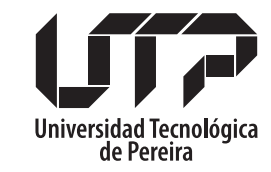

Colección Tesis Laureada

Facultad de Ciencias de la Educación

Doctorado en Ciencias de la Educación

2015 
Orozco Giraldo, Consuelo, Conexión Emoción - Razón : En busca de la unidad perdida en el plano educativo /

Consuelo Orozco Giraldo. - Pereira: Editorial Universidad Tecnológica de Pereira, 2015.

138 páginas. - (Colección Tesis Laureadas).

ISBN: 978-958-722-237-1

1. Sociología contemporánea 2. Filosofía antigua 3. Platón 4. Aristóteles 5. Racionalismo

Espiritualidad 7. Conductismo.8. Sociología de la educación.

CD. 306.432

(C) Consuelo Orozco Giraldo, 2015

(C) Universidad Tecnológica de Pereira

\section{Primera edición}

ISBN: 978-958-722-237-1

\section{Universidad Tecnológica de Pereira}

Vicerrectoría de Investigaciones, Innovación y Extensión

Editorial Universidad Tecnológica de Pereira

\section{Coordinador editorial:}

Luis Miguel Vargas Valencia

luismvargas@utp.edu.co

Conmutador 3212221 Ext. 381

Edificio 9, Biblioteca Central "Jorge Roa Martínez"

Cra. 27 No. 10-02 Los Álamos

Pereira, Colombia

www.utp.edu.co

\section{Montaje y producción:}

Centro Recursos Informáticos y Educativos - CRIE

Universidad Tecnológica de Pereira

Ilustación Cubierta:

Ruben Dario Gutiérrez

Montaña Urbanizada

Acuarela y tintas

Impresión y acabados:

Publiprint

\section{Reservados todos los derechos}




\section{Tabla de Contenido}

Introducción $\quad 6$

$\begin{array}{ll}\text { I. Hitos de la educación tradicional } & 7\end{array}$

$\begin{array}{ll}1.1 \text { Platón, el filósofo de la escritura } & 7\end{array}$

1.2 Escritura: bajo el signo de la permanencia $\quad 8$

1.3 La existencia de dos mundos: Mundo que permanece - Mundo que cambia 8

1.3.1 El mundo inteligible o kósmos noetós 99

1.3.2 Mundo sensible o kósmos horatós $\quad 9$

$\begin{array}{ll}1.4 \text { La división tripartita: tres clases sociales } & 10\end{array}$

$\begin{array}{ll}1.5 \text { La división tripartita: tres almas, tres virtudes } & 11\end{array}$

1.5.1 Las implicaciones alrededor del concepto de alma:

Tres tipos de hombre, tres tipos de alma 11

1.5.2 Tres virtudes 14

$\begin{array}{ll}1.6 \text { Otras consecuencias } & 15\end{array}$

1.6.1 Expulsión de los poetas, por no ser universal y sí emocional $\quad 15$

$\begin{array}{ll}1.7 \text { Hay placeres falsos (Filebo) } & 18\end{array}$

$\begin{array}{ll}1.8 \text { Implicaciones educativas } & 21\end{array}$

1.9 Aristóteles, títere de la gramática $\quad 22$

$\begin{array}{ll}1.9 .1 \mathrm{El} \mathrm{Cosmos} & 23\end{array}$

$\begin{array}{ll}\text { 1.9.2 Materia y forma } & 24\end{array}$

$\begin{array}{ll}1.9 .3 \mathrm{El} \mathrm{alma} & 24\end{array}$

1.9.4 El lenguaje $\quad 25$

1.10 La metáfora y el lenguaje $\quad 26$

$\begin{array}{ll}1.11 \text { Implicaciones educativas } & 27\end{array}$

1.12 Juan Amós Comenio, universalismo hecho didáctica 27

$\begin{array}{ll}1.13 \text { El Conductismo } & 30\end{array}$

1.13.1 Iván Petróvich Pavlov $\quad 31$

$\begin{array}{ll}\text { 1.13.2 John Broadus Watson } & 31\end{array}$

$\begin{array}{ll}\text { 1.13.3 Burrhus Frederic Skinner } & 33\end{array}$

1.14 Sobre el conductismo $\quad 33$

1.15 Concepciones educativas desde el condicionamiento operante $\quad 37$

$\begin{array}{ll}1.16 \text { Implicaciones educativas } & 38\end{array}$

II. Crisis de las fórmulas $\quad 39$

$\begin{array}{ll}2.1 \text { Sociología contemporánea } & 39\end{array}$

2.1.1 Gilles Lipovetsky $\quad 41$

2.1.2 Sigmund Bauman $\quad 49$

2.2 Lenguaje $\quad 52$

2.2.1 Giro Lingüístico $\quad 52$

2.2.1.1 Frederick Nietzsche 53

2.2.1.2 Benjamin Whorf $\quad 55$

2.2.1.3 John Langshaw Austin $\quad 56$

2.2.1.4 Lakoff \& Johnson $\quad 58$ 
2.3 Filosofía

2.3.1 Adam Smith $\quad 59$

$\begin{array}{ll}\text { 2.3.2 John Dewey } & 61\end{array}$

2.3.3 Peter F. Strawson $\quad 64$

$\begin{array}{ll}\text { 2.3.4 Martha Nussbaum. Sin fines de lucro } & 65\end{array}$

III. Reivindicación de la emoción $\quad 66$

3.1 La Ciencia no se detiene $\quad 66$

3.2 Antecedentes en la educación. Prácticas liberadoras 67

3.2.1 Paulo Freire: pedagogía del oprimido, pedagogía de la autonomía $\quad 67$

3.2.2 Augusto Boal: teatro del oprimido $\quad 68$

3.2.2.1Teatro del oprimido $\quad 69$

3.2.3 Martha Nussbaum: Justicia poética $\quad 73$

3.3 Neurofisiología de la conexión emoción-razón 74

3.3.1 Paul MacLean. Fisiología de la conexión emoción-razón. Cerebro trino 78

$\begin{array}{ll}\text { 3.3.2 Antonio Damasio } & 81\end{array}$

3.3.3 Joseph LeDoux $\quad 84$

3.3.4 Luis Carretié Arangüena $\quad 86$

3.3.5 Humberto Maturana. Emociones y lenguaje en educación y política $\quad 88$

3.3.6 Howard Gardner. Intelligence reframed.

Multiple intelligences for the 21st century $\quad 91$

IV. Implicaciones educativas $\quad 95$

4.1 Metodología 95

$\begin{array}{ll}4.2 \text { Suposiciones o hipótesis } & 101\end{array}$

$\begin{array}{ll}4.3 \text { Población } & 102\end{array}$

$\begin{array}{ll}4.4 \text { Técnicas de recolección de datos } & 103\end{array}$

$\begin{array}{ll}4.5 \text { Exploraciones transversalizadoras } & 104\end{array}$

4.5.1 Elementos comunes a las exploraciones propuestas $\quad 104$

$\begin{array}{ll}\text { 4.5.1.1 Interactividad } & 104\end{array}$

$\begin{array}{ll}\text { 4.5.1.2 Perlocutividad } & 105\end{array}$

$\begin{array}{ll}\text { 4.5.1.3 Transversalidad } & 105\end{array}$

4.5.1.4 Conexión emoción-razón $\quad 105$

$\begin{array}{ll}\text { 4.5.1.5 Multisensorialidad } & 106\end{array}$

4.6 Exploración 1. Cine 106

4.7 Exploración 2. Teatro del oprimido 109

$\begin{array}{ll}4.8 \text { Encuesta } & 112\end{array}$

4.9 Encuesta A. Generalidades $\quad 115$

4.9.1 Análisis de los resultados de la encuesta A 116

4.10 Encuesta B. Generalidades $\quad 123$

4.10.1 Análisis de los resultados de la encuesta B $\quad 124$

Conclusiones y recomendaciones $\quad 130$

$\begin{array}{ll}\text { Bibliografía } & 132\end{array}$ 


\section{Tabla de figuras}

Figura 1. Presencia de la conexión emoción-razón en la publicidad 46

Figura 2. Presencia de la conexión emoción-razón en la política 47

Figura 3. The tree of the theater of the oppressed $\quad 72$

Figura 4 . Cerebro trino de Paul MacLean. 78

Figura 5. Estructura del sistema límbico de Paul MacLean $\quad 80$

Figura 6. Representación esquemática del circuito de evitación de Luis Carretié $\quad 87$

Figura 7. Algunas diferencias entre ciencias exactas y humanidades 96

$\begin{array}{ll}\text { Figura 8. Ruta metodológica ideal } & 97\end{array}$

Figura 9. Ruta metodológica real 98

$\begin{array}{lr}\text { Figura 10. Nuevas exploraciones } & 99\end{array}$

Figura 11. Vista frontal del móvil 100

Figura 12. Vista cenital del móvil 100

Figura 13. Lecturas del móvil 101

Figura 14. Relación de técnicas y exploraciones aplicadas $\quad 104$

Figura 15 Clasificación de áreas y categorías $\quad 112$

$\begin{array}{ll}\text { Figura 16. Formato de la encuesta A } & 114\end{array}$

Figura 17. Pregunta $1 . \quad 116$

Figura 18. Pregunta 2. 116

$\begin{array}{ll}\text { Figura 19. Pregunta } 3 . & 117\end{array}$

$\begin{array}{ll}\text { Figura 20. Pregunta } 4 . & 118\end{array}$

Figura 21. Pregunta $5 . \quad 118$

Figura 22. Pregunta $6 . \quad 119$

Figura 23. Estudiantes desarrollando actividades con las exploraciones trasversales $\quad 120$

$\begin{array}{ll}\text { Figura 24. Pregunta } 7 . & 120\end{array}$

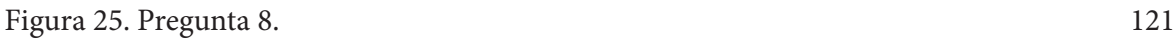

Figura 26. Pregunta 9. 122

Figura 27. Pregunta $1 . \quad 124$

Figura 28. Pregunta $2 . \quad 125$

Figura 29. Pregunta $3 . \quad 126$

Figura 30. Pregunta $4 . \quad 126$

$\begin{array}{ll}\text { Figura 31. Pregunta } 5 . & 127\end{array}$

$\begin{array}{ll}\text { Figura 32. Pregunta } 6 . & 127\end{array}$

$\begin{array}{lr}\text { Figura 33. Pregunta } 7 . & 128\end{array}$

$\begin{array}{lr}\text { Figura 34. Pregunta } 8 . & 128\end{array}$

Figura 35. Pregunta 9 


\section{Introducción}

En proceso de mancipación de la religión, la sociedad va logrando múltiples trasformaciones que se hacen cada vez más profundas y que cambian a la velocidad del vértigo. Rastrear en las personas las mencionadas trasformaciones no sería tarea difícil. Otras formas de hablar, de pensar, de vestir, y de comunicarse son algunos ejemplos prototípicos que justifican que nos ocupemos de una sociedad diferente. La academia, sin embargo, continúa educando para una sociedad que ya no existe o por lo menos no es la que viven los jóvenes. Con estrategias del pasado sometidas no solo al modelo de racionalidad instrumental, sino, además, al margen de la legitimidad del otro, de las diferencias y sobre todo de la emoción, la academia se hace cada vez más anacrónica.

Reivindicar el protagonismo de la conexión emoción-razón, en virtud de sus beneficios académicos, emocionales y sociales, resulta perentorio en una sociedad que se deshumaniza cada vez más por la racionalidad instrumental y el consumo emocional desenfrenado.

En el primer capítulo titulado "Hitos de la educación tradicional", nos preocupamos por las circunstancias socioculturales a través de las cuales el dualismo razón-emoción se consolida en Occidente y se instala, casi sin darnos cuenta, en el ámbito educativo. En el segundo capítulo titulado "Crisis de las fórmulas" rastreamos desde la sociología, el lenguaje y la filosofía, hallazgos que nos obligarían a poner en tela de juicio ciertos discursos y prácticas pedagógicas que pretenden educar con fórmulas. En el tercer capítulo titulado "Reivindicación de la emoción”, nos proponemos rescatar la relación razón-emoción a partir de los avances registrados en las últimas décadas por investigadores en el campo de la neurociencia. En el último capítulo titulado "Implicaciones educativas", lejos de proponer un Método que funcione para todos, ponemos en escena algunas exploraciones educativas que dan cuenta del poder de la conexión emoción- razón especialmente en el campo educativo. 


\section{Hitos de la educación tradicional}

Las numerosas e ideales categorías almacenadas desde Platón y Aristóteles, las mismas que pretenden dar cuenta de los fenómenos naturales o los hechos históricos, han gozado de vigencia y falta de aduana durante siglos. Es cuando de un lado, se reduce la filosofía a la metafísica, y del otro, se construyen taxonomías, ya de las almas y la sociedad (Platón), ya del lenguaje y los seres vivos (Aristóteles), ya de la interacción en clase y del proceso educativo (Comenio), ya del asociacionismo del comportamiento (Skinner).

Nos preguntamos por las circunstancias socioculturales a partir de las cuales los términos razón y emoción se consolidan en Occidente como antagonistas. Adelantar su reconexión en el plano educativo, es nuestro mayor interés, para ello, se intentará un rastreo por pensadores ya mencionados, cuyo común denominador radica en la repercusión de sus ideas y planteamientos en el plano educativo. La República de Platón subordina la educación a la política en su Polis Ideal, la misma que pretende responder de una vez por todas las preguntas formuladas por Sócrates. El discípulo de Platón, Aristóteles, heredaría la pregunta por los universales, y en su condición de biólogo, estaría habilitado, además, para construir taxonomías, lo cual se hace evidente particularmente es sus obras de biología y de lógica, entre ellas, De la interpretación. Didáctica Magna, es la pansofía de Comenio y su apuesta por un Método que permita "enseñar todo a todos" como si todos fuéramos iguales. En ella, se uniforma el conocimiento y se suprime toda posibilidad de pluralidad educativa y pedagógica. Finalmente, Sobre el conductismo de Skinner, es un escrito que permite rastrear la mayéutica vergonzante de estirpe socrática que ignora la autonomía y manipula el comportamiento y la multiplicidad de las reacciones humanas. Skinner y su conductismo operante cierran este coctel de casi siempre desafortunadas teorías.

Al solapar las diferencias, entre los hombres o al hacerlas secundarias, los autores antes mencionados proponen fórmulas universales detrás de las cuales es posible identificar un cierto biologismo a partir del cual todos los individuos humanos hacen parte de la misma especie sin tomar en consideración las profundas diferencias surgidas de contextos distintos, lenguas distintas, construcciones políticas y económicas distintas que no permitirían legitimar una concepción universalista del ser humano más a la de su aspecto biológico. En síntesis, estos pensadores apuestan por el universalismo y todo universalismo es un reduccionismo.

\subsection{Platón, el filósofo de la escritura}

"Rubor avergonzado de Platón" (Nietzsche, más allá del bien y del mal). Como el mundo verdadero terminó convertido en fabula, después de hacernos creer durante siglos que el mundo en lo esencial no cambia, Platón habló de modelos y a partir de entonces los filósofos fueron platónicos. Aristóteles buscó fines, la escolástica definió a dios y cuadriculó la experiencia religiosa. Descartes idealizó el yo y Kant descontextualizó a la razón. A partir de Nietzsche, no obstante, hemos desmantelado las falacias de la filosofía y sabemos que el ser es una extracción 
y que el mundo no es más que devenir.

Dos circunstancias históricas se alinean para explicar los planteamientos de Platón. Un par de siglos después de haber llegado la escritura alfabética en Grecia, su enseñanza se incorpora al proceso educativo, de un lado. Perteneciente a la familia de los Eupatrida, de cuyo linaje salían los gobernantes de Atenas, Platón toma partido por los suyos en un intento por colocar un dique a las nuevas ideas y prácticas sociales en condiciones de colocar en entredicho su predominio. Desde entonces, el cambio tomó vestigios de amenaza para Platón representando un dique al futuro. La idea de construir una ciudad perfecta sería solo una de ellas.

Que los hábitos intelectuales de Platón hayan sido permeados por la escritura, lo hizo sensible al esencialismo y al universalismo y lo Eupatrida lo hizo sensible a la Polis Ideal. En síntesis, Platón por su formación intelectual y por su actividad práctica hizo la filosofía política de corte esencialista y universalista. Después de sus infructuosos viajes a Siracusa para fundar la ciudad perfecta, Platón regresa a Grecia y funda la academia logrando desarrollar como profesor lo que no pudo hacer como político. Leemos en La República:

Si nuestros ciudadanos son bien educados y se hacen hombres de regla, verán por si mismos fácilmente la importancia de todos estos puntos y de muchos otros que omitimos aquí [...] en un estado todo depende de los principios [...] por tanto, para decirlo en dos palabras los que hayan de estar a la cabeza de nuestro Estado vigilaran especialmente para que la educación se mantenga pura; y; sobre todo para que no se haga ninguna innovación [...] (Platón, 1966, p. 121).

Fiel a los principios platónicos, la academia se ha mantenido estacionada entrenando para la permanencia, en un mundo que reclama seres entrenados para el cambio.

\subsection{Escritura: bajo el signo de la permanencia}

Lejos de abrir mundos posibles como lo haría la oralidad, la popularización de la escritura, traería consigo la idea de un mundo diferente, perfecto e inmóvil, el mundo de la escritura, ajeno a las vicisitudes de la vida humana. Caracterizado por la permanencia y la intelectualidad y con fines en sí mismo, este mundo de la escritura separa lo físico de lo intelectual, lo sensible de lo inteligible, lo universal de lo particular y el ser del devenir.

De espaldas a la humildad, la escritura asume características de omnipresencia cuando desplaza el contexto y pretende significar por fuera de él. Que haya permanencia del significado en las palabras ajeno al contexto, es un engaño gestado por la escritura y que la academia ha perpetuado sin beneficio de aduana.

\subsection{La existencia de dos mundos: Mundo que permanece - Mundo que cambia}

La idea de dos mundos separados y opuestos, es tal vez, la idea platónica más fuerte, la misma que da origen a las demás. Un mundo sensible y otro inteligible, le permite gestar el maniqueísmo platónico del que somos hijos. Con características propias, cada uno de estos 
mundos concibe formas propias de vivir, de sentir, de actuar y de posible realidad. Con carácter totalizante por la concepción de verdad, la vida intelectual es despojada de su condición plural y centrada en doctrinas platónicas que podrían resumirse en tres ideas fundamentales: La existencia de dos mundos, tres tipos de hombre y una forma de política.

\subsubsection{El mundo inteligible o kósmos noetós}

Con características inmateriales, ajenas al cambio, eternas e indestructibles, la realidad del mundo inteligible constituye el modelo o arquetipo del otro mundo, el sensible o visible. Concebida la verdad como las cosas que no cambian, el mundo inteligible o de las ideas, sería objeto de "episteme". Con atributos eternos, el mundo de las ideas continúa su vigencia a pesar de la historia, del cambio, de la muerte del cuerpo, inclusive.

Los modelos o arquetipos constituyen "esencias" o "ideas" únicas, eternas e inmutables, que no pueden ser objeto de conocimiento sensible, sino, inteligible a través de la razón. Asignado el papel estelar a los modelos o arquetipos, y en la medida en que las copias, y en particular los seres humanos, se subordinan al original, el tiempo plural, queda preso del totalitarismo y la racionalidad instrumental, acreditada por la academia. Si el fin del saber, de acuerdo con Platón, es recordar el mundo de las ideas, con la teoría del conocimiento como reminiscencia, es evidente que solo el alma racional en su condición de alma inmortal, preexistente estaría en condiciones de conocer el mundo de las ideas y en particular de recordarlo. En otras palabras, si las entidades del mundo de las ideas, por su condición de "reales y verdaderas" están más allá del tiempo y del espacio, si solo serían cognoscibles, a través de la parte más excelente del alma, es decir, la racional, en el mundo de las ideas solo participarían aquellos que con alma racional, poseen, además, el poder para gobernar, Platón, un Eupatrida estaría entre ellos.

De la dependencia del mundo sensible respecto de la inteligible, abundan los corolarios como sería el predominio del protagonismo (nous) del pensamiento, sobre el lenguaje (logos). Reducido el arte del diálogo y la discusión al ejercicio adecuado de la razón para el descubrimiento de la verdad, es decir, del mundo de las ideas, las conversaciones propias del socratismo, en adelante, estarían sometidas a la racionalidad instrumental. Si no habitamos un país sino una lengua (Cioran), si el lenguaje aporta sentidos y configura nuestra vida, ¿por qué continuar reduciendo el lenguaje al papel y a la tinta, a la falsa figura sombría de lo ajeno a nuestras vidas, a lo lejano e impenetrable, a lo enigmático e indecible?

\subsubsection{Mundo sensible o kósmos horatós}

El platonismo situó el auténtico ser en lo universal, lo inmutable y lo eterno. Su contraposición, definió lo individual, lo efímero y lo sensible como la simple apariencia del ser. Constituido por lo que ordinariamente llamamos "cosas", es decir, soportes de atributos de acuerdo con la sintaxis que nos gobierna, este mundo posee características materiales, corruptibles, sometidas al cambio y a la destrucción. Este mundo sensible y pagano, de acuerdo con Platón, es una copia de la realidad inteligible, es decir, del mundo de las ideas.

Lejos de ser "real", el mundo sensible o de las cosas, queda relegado a la mera opinión o "doxa”. 
Los objetos sensibles son débiles copias de una realidad inmutable y eterna constituida por el mundo de las ideas. Construido por objetos físicos y sus sobras (idea recreada en el mito de la caverna), al mundo sensible accedemos solo a través de los sentidos. En virtud de sus características versátiles, cualquier conocimiento sobre ellos es relativo y temporal, por lo tanto, a la larga una falacia.

Sometido al tiempo y al espacio, el mundo sensible, representa la cárcel humana por excelencia, idea de estirpe órfica. Separado el cuerpo del alma, conocer la realidad a través de los sentidos resulta imposible, cuando solo permite al alma recordar a través de los sentidos una realidad que ya existía antes de ser encarcelada en el cuerpo.

Si la mente construye el mundo, de acuerdo con las ideas constructivistas que han hecho carrera en las últimas décadas, no solo la teoría platónica del mundo sensible, en la cual el hombre opera como extra y no como actor principal, queda en entredicho, sino, además, la posibilidad de emanciparse de las contingencias del devenir. Someter la vida humana a lo sensible, sin posibilidades de lo inteligible sino a través del alma racional (posibilidad de pocos de acuerdo con Platón), es una posición excluyente, maniquea y reduccionista que termina por garantizar nuestra desventura.

\subsection{La división tripartita: tres clases sociales}

En La República, Platón no solo hace gala del maquiavélico "divide y vencerás", sino que, además, se pregunta, entre otras cosas, por la justicia, la moral, la verdad y el ideal político. Al ocuparse de estas cuestiones, el discípulo de Sócrates, dará paso a la división de las clases sociales y las partes del alma, a la Polis Ideal y a los fines de la educación. La división de la Polis en tres clases sociales a través del proceso educativo, es la vía elegida por Platón para la construcción de una sociedad ordenada, lo que facilitaría a la clase dominante mantener el control.

Lejos de ser arbitraria, la división por clases de la Polis se funda en la psicología de Platón, en la cual es posible verificar una correspondencia unívoca entre las clases sociales y las partes del alma. Que la tendencia a fragmentar proporcione poder, se registra no solo en el plano social y político, sino, además, en la vida intelectual. Fragmentar el saber facilitaría su comprensión además de su dominio. En tales circunstancias, no debe extrañarnos que dicha tendencia taxonómica, que el más afamado de sus discípulos llevara todavía más lejos, se haga extensiva a la educación, cuando prefigura sus horizontes de sentido, entre otras cosas, a través de su célebre consigna: "zapatero a tus zapatos" (Platón, 1966, p. 92).

No debe extrañarnos que la concepción tripartita platónica, se pueda verificar en algunos descubrimientos en el campo de las Ciencias Sociales. En los hallazgos de George Dumézil, por ejemplo, se registra una tendencia en la cultura de los pueblos que hablan lenguas indoeuropeas al fraccionamiento, de donde surge la teoría de la división tripartita de la sociedad presente, por ejemplo, en los arios y los iranios, los griegos y los romanos, los celtas y los germanos, por mencionar solo algunos. En dicha división tripartita se distinguen tres grupos: al primer 
grupo corresponden las funciones de mando, el segundo es el que hace la guerra, y el tercero es el encargado de las funciones productivas.

Vida y pensamiento adquieren características propias en cada uno de los grupos señalados por Dumézil, los cuales además de incluir los aspectos más significativos de la vida social y religiosa, especialmente toman en cuenta su organización cultural. Esta concepción tripartita, a su vez, nos permite distinguir tres funciones: la soberanía, en su doble aspecto mágico y jurídico; la guerrera que privilegia las virtudes de la valentía y el honor; y la función productiva que gira, primero, alrededor de la caza y, después, de la agricultura.

No sólo la sociedad se divide en tres grupos, cuando, además, la concepción tripartita se hace extensiva a la mitología. Leemos en los dioses de los indoeuropeos:

[...] Estas tres funciones son: 1) la administración a la vez misteriosa y regular del mundo; 2) el juego del vigor físico, de la fuerza, principalmente guerrera; 3 ) la fecundidad, con muchas condiciones y consecuencias tales como la prosperidad, la salud, la longevidad, la tranquilidad, la voluptuosidad (Dumézil, 1977, pp. 12 - 13).

La organización de las tres funciones identificada por Dumézil da cuenta de una sociedad jerarquizada, cuyas funciones específicas y vitalicias amplían sus posibilidades de supervivencia. Según Dumézil, "estas tres funciones corresponden a tres necesidades que todo grupo humano debe satisfacer a riesgo de perecer de no hacerlo" (Dumézil, 1977, p. 605).

Asignadas las funciones, cada una expresa formas propias de percibir, conocer, pensar, expresarse y realizar de manera independiente de las demás. Las personas, sin posibilidad de elegir, se dedicaban a una sola actividad: únicamente podían desempeñar labores de magos, guerreros o pastores, poniendo especial énfasis en que cada uno debía dedicarse a lo suyo, fórmula que les permite abastecerse y cumplir los requisitos necesarios para sobrevivir y sortear contingencias.

Esta división de la sociedad entre grupos humanos claramente diferenciados y con funciones específicas, aparte de hacerse evidente en la cultura de los pueblos que hablan lenguas indoeuropeas, puede verificarse en una de las más reputadas obras de la antigüedad clásica: $L a$ República de Platón.

\section{I.5 La división tripartita: tres almas, tres virtudes}

\subsubsection{Las implicaciones alrededor del concepto de alma: Tres tipos de hombre, tres tipos de alma}

Seres humanos con tres tipos de alma, una de las cuales tendría origen divino, la racional, es el resultado de la distinción platónica entre cuerpo (soma) y alma (psyché), en la que el primero cede importancia ante la última que no solo participa de los universales del mundo inteligible, cuando, además, deslinda lo racional de lo emocional. El alma, de un lado, sería 
aquello, común en los seres vivos, que les permite adelantar sus funciones básicas como tales, es decir, el metabolismo y la reproducción. Y de otro lado, sería inmaterial, esencia humana, principio y fundamento del conocimiento humano, en condiciones de participar del mundo de las ideas. En lo sucesivo, es posible reconocer en el alma no solo autonomía y singularidad sino, además, identidad.

Tomada de Orfeo la idea de alma, y habiendo tres tipos de ella para Platón: alma concupiscible, alma irascible y alma racional (presentes también en el mito del carro alado del Fedro, los dos caballos y el auriga representan las tres partes del alma: epithimetikón: el apetito (el caballo malo), thimoeides: el coraje (el caballo bueno), y logistikón: la razón, la pertenencia al logos (el auriga)), habrá tres tipos de hombre según predomine la una o la otra en cada uno: la producción material, las necesidades básicas humanas como el placer y la alimentación estarían presentes especialmente en quienes predomina el alma concupiscible; la voluntad, la fortaleza y el valor para la guerra, en quienes predomina el alma irascible y gobierno, la inteligencia y la sabiduría, en quienes predomina el alma racional, de naturaleza divina, eterna e inmortal. Señalado el tipo de alma, no habría manera de cambiarla.

[...] la primera de estas es aquella por la que el hombre conoce; la segunda es aquella por la que el hombre se irrita [...], la tercera la hemos llamado apetito concupiscible a causa de la violencia de los deseos que nos arrastran a comer, a beber y a los demás placeres de los sentidos (Platón, 1966, p. 300).

Habiendo definido Platón en La República su ideal político, el individuo debe obedecer a su alma y desempeñar las tareas que le corresponden. De la conveniencia de que cada quien se ocupe de aquellas tareas que responden a la parte del alma más desarrollada, da cuenta Platón en el siguiente pasaje:

[...] construyamos pues un Estado con el pensamiento. Nuestras necesidades serán evidentemente su base [...], se ha fijado en mi pensamiento que no todos nacemos con el mismo talento, y que unos tienen más disposición para hacer una cosa y otro la tiene para otra [...] ¿cómo irán mejor las cosas, haciendo cada uno muchos oficios o limitándose cada uno al suyo propio? (pp. 57).

Si las fortalezas de cada persona no son las mismas, lo racional, de acuerdo a Platón sería concentrarse cada uno a lo suyo, es decir, a sacar partido de sus habilidades. Si cada quien hace aquello para lo cual está mejor dotado, la sociedad en su conjunto se verá beneficiada.

Que no exista igualdad entre las tres partes del alma que cita Platón en La República, se hace evidente cuando solo la racional es inmortal, de la misma forma, tampoco hay igualdad entre las clases sociales porque el poder es propio de los guardianes, que pueden ejercer el poder gracias a su dotación de alma racional.

[...] ya si cuanto más importante es el cargo de estos guardianes del Estado, tanto mayores deben de ser el cuidado, el estudio y el tiempo que a ellos se consagre - ¿y no se necesita disposición natural para desempeñar semejante cargo?- sin duda, a 
nosotros nos corresponde escoger, si podemos, entre los diferentes caracteres los que son más propios para la guarda del Estado- esta elección es de nuestra incumbencia (pp. 63).

Presupuestada la concepción esencialista del ser humano, la no movilidad social sería un corolario. Aunque la inferencia es correcta, el punto de partida es falso. Desde cuando el hombre deslinda los medios de los fines en el paleolítico, se hace evidente la existencia del futuro como horizonte abierto de posibilidades. De allí la facilidad de cambiar de profesión a lo largo de la vida, desdecirnos y repensarnos de cara a la contingencia.

Dominando con su poderío, avasallando con el universalismo y en contravía con los ideales democráticos, los gobernantes-guardianes son vitalicios, todo lo cual daría lugar a múltiples abusos.

Sólo a los magistrados supremos pertenece el poder de mentir, a fin de engañar a los enemigos o a los ciudadanos para bien de la República. La mentira no debe permitirse nunca a los demás hombres [...], por consiguiente si un magistrado coge en mentira a algún ciudadano [...] le castigará severamente [...]; la justicia hace bien a sus amigos y mal a sus enemigos [...] la justicia no es otra cosa que lo que es provechoso al más fuerte (pp. 15, 23).

No debe extrañarnos así que Platón haya sido reconocido como uno de los teóricos de la sociedad cerrada (Popper), y se le identifique, además, como censurador por excelencia del arte (Dewey). La fórmula de la división tripartita platónica, se hace aun más evidente cuando expresa en La República su célebre consigna: «zapatero a tus zapatos».

No hemos querido que el zapatero fuese al mismo tiempo labrador, tejedor o arquitecto, sino sólo zapatero [...], sin permitirle mezclarse con el oficio de otro, ni tener durante su vida, otra ocupación que la perfección del suyo [...], en nuestro Estado el zapatero es simplemente zapatero y no piloto; el labrador, labrador y no juez; el guerrero, guerrero y no comerciante, y así los demás (pp. 63 - 93).

La segunda y tercera alma irascible y la concupiscible respectivamente, a diferencia de la primera, resultan ser irracionales y proceden de la tendencia griega de otorgarle alma a todos los seres vivos. A continuación la clasificación de las almas según Platón.

\begin{tabular}{|c|c|c|c|c|}
\hline Alma 1 & Racional & Espiritual & Inmortal & $\begin{array}{r}\text { El alma en definitiva es forma. La forma } \\
\text { nos da identidad intelectual }\end{array}$ \\
\hline Alma 2 & Irracional & Corporal & Mortal & En definitiva es materia \\
\cline { 1 - 1 } Alma 3 & & & & \\
\hline
\end{tabular}

Todo lo que no es racional ni espiritual es irracional, por lo tanto, el instinto y la emoción no son racionales, de acuerdo con Platón. Aunque esta separación alma-cuerpo ha hecho carrera, 
ya no es posible sostenerla porque el cerebro, al que se le atribuye toda actividad racional, es corporal.

Dada la dicotomía mortal-inmortal, la educación, de acuerdo con Platón, debe obedecer a lo superior y no a lo inferior, por lo tanto, la educación debe ser racional. Que la emoción esté ocupando un segundo lugar en la educación, se debe a que en esta división quedó del lado del alma mortal, porque la emoción es más evidente en la participación del cuerpo (el sexo por ejemplo) que en la razón. Desde entonces, se simula que la razón no es corporal sino espiritual. Si lo intelectual es lo superior y racional y el cuerpo es lo sensible, la educación debe educar en lo racional. Si la razón separada del cuerpo y del mundo hace posible una reflexión descontextualizada, no estaría comprometida con las diferencias de suerte, para Platón, que hará posible la construcción de lo universal. No obstante, abstraer un hecho o una persona de las circunstancias no es más que un artificio didáctico. La separación hombre-mundo no es más que una abstracción, no existe el sujeto al margen del mundo como lo ha hecho evidente la hermenéutica de Heidegger y el constructivismo radical.

Al margen del mundo y del cuerpo, la razón no necesita el ajuste continuo a los cambios, por lo tanto, se convierte en racionalidad instrumental porque puede definir previamente los fines, no siendo otro el objetivo primordial de la educación actual, que planea con objetivos previos y conocidos para estudiantes posteriores y desconocidos.

Lejos de dar protagonismo a la emoción que nos ajusta constantemente al contexto, la academia continúa entrenado para la permanencia en un mundo, no obstante, contingente. Si el cuerpo es mortal y la emoción pertenece al cuerpo, ni cuerpo ni emoción pueden ser racionales, por lo tanto, la educación debe ignorarlos. En síntesis, tenemos una educación racionalista basada en una antropología platónica.

\subsubsection{Tres virtudes}

Las implicaciones educativas alrededor de la virtud están relacionadas con la justicia, la prudencia y la templanza. La justicia es la virtud fundamental de la cual se derivan todas las demás virtudes, pues constituye su principio armónico. La prudencia (calculativo, viene del ejercicio de razón,), la fortaleza (enérgico, ejercer las emociones o el espíritu) y la templanza (apetitivo, dejar que la razón anule los deseos), son estas virtudes las que constituyen un ciudadano relevante, útil y perfecto. Platón describe la justicia como la virtud fundante y preservante porque solo cuando alguien la comprenda puede conseguir las otras tres virtudes. Cuando alguien posee las cuatro virtudes es la justicia que fiel a su trabajo, mantiene todo junto.

El conflicto trágico tuvo lugar cuando los griegos evidenciaron las diferencias entre sus fines. Al presentar distintos presupuestos, las decisiones no son comparables, es decir, si una persona busca la felicidad y la otra la bondad, es obvio que buscan cosas distintas. Pretender uniformar nuestros deseos y fines, es una falacia en la que estamos atrapados. Si somos muchos a la vez, es evidente que tenemos nuestros propios conflictos trágicos. 
De la pluralidad del ser humano da cuenta Platón cuando unifica y armoniza a través de la idea de justicia (zapatero a tus zapatos) las formas en que debían percibir, sentir y actuar. Si cada quien busca algo de acuerdo a sus prioridades, todos terminan buscando cosas diferentes. Manipulada la idea de justicia, solo son justos quienes se dedican a lo que su alma les permite. Erradicados estos "males", las personas quedan atrapadas en el ideal platónico "la uniformidad, evitar pensar y sentir".

Diremos que lo que hace al Estado justo, hace justo al particular [...], no hemos olvidado que el Estado es justo cuando cada uno de los tres órdenes que lo componen hace únicamente lo que es de su deber. Acordémonos de que cada uno de nosotros será justo y cumplirá su deber cuando cada una de las partes de sí mismo realice su tarea (pp. 143).

Un gobierno con régimen totalitario, fue la idea platónica que terminó por disfrazar de unidad la pluralidad humana de la Polis, de esta forma la gente no cambiaría la sociedad. Prohibidas las almas divergentes, tal y como sucede en la reciente película "Divergente" de Neil Burger, la educación es totalitaria. Verdad (sinceridad), erudición (inteligencia), cordialidad (la paz) osadía (valentía) y abnegación (generosidad).

$\mathrm{Al}$ dividir en tres las almas y con la idea de justicia, Platón logró atar y unificar su Polis en contra del conflicto trágico y el intelectualismo (Protágoras), y a favor del universalismo.

\section{I.6 Otras consecuencias}

\subsubsection{Expulsión de los poetas, por no ser universal y sí emocional}

Si la virtud en Platón son las tres almas que están dentro de la idea de justicia, versus poetas trágicos y Protágoras, la educación está fundada como instrucción y la emoción es subjetiva, por lo tanto, un peligro. En síntesis, lo justo y racional es una educación agelasto.

Alma-cuerpo, procede de la escritura. De ahí la distinción razón-emoción, versus el cerebro triuno (MacLean), este último nos permite comprender que son tres en uno. Esto llevó a rechazar al mismo tiempo, el cuerpo por ser un peligro en la religión y la emoción un peligro en la educación. La distinción cuerpo-alma fue aprovechada por los órficos inicialmente, Platón la copió, por eso expulsó los sacerdotes itinerantes.

Eludir hábitos intelectuales maniqueos y conductas comprometidas con el totalitarismo, el consumismo y el individualismo sería un compromiso educativo. Sensibilizar y humanizar la tradición académica sobre la importancia de ciertos actos educativos que inciten a pensar y a cuestionar el statu quo, sería una tarea pendiente. Pretender, en cambio, que cada uno se dedique a lo suyo, es ingenuo, porque el hombre es también emoción, pasión e instinto, que si bien reclaman la presencia de los demás, son descalificados por Platón como peligrosos.

Obliguemos a los poetas a no componer nada [...]. Conjuremos a Homero y a los demás poetas a que no lleven a mal que borremos de sus obras estos pasajes y Otros 
semejantes. No porque no sean muy poéticos y que no halaguen agradablemente el oído del público; pero cuanto más bellos son, tanto son más peligrosos para los niños y para los hombres [...]; luego con razón suprimimos en los hombres ilustres las lágrimas y los gemidos y los reservamos a las mujeres (pp. 68 - 77).

De la misma forma, cuando en los diálogos platónicos presentes en La República, se refieren a aquello que aprobaran o no de Homero, por unanimidad deciden desaprobar lo que representaría liberación "y sigue así como todas las injurias que los poetas y los demás escritores ponen en boca de los inferiores en contra de los superiores" (pp. 82).

La urgencia platónica de impugnar los sentimientos por inmorales, haría inviable nuestra especie. La naturaleza habilitó la emoción como sistema de reacción inmediata sin el cual no hubiera sido posible construir, de otro lado, una sociedad en la que los hijos demandan cuidado durante largo tiempo. Si los estados afectivos indican estados internos personales, motivaciones, deseos, necesidades e incluso objetivos, es menester repensar las estructuras sociales y educativas, de suerte que se reconozca el protagonismo de la emoción sin el cual la motivación y la memoria demandarían ingentes esfuerzos de la voluntad para salir adelante.

El pensamiento único, caracterizado por el destierro de la emoción y el arte, la educación con fines políticos, la división tripartita del alma y la sociedad y el universalismo, son aspectos destacados en La República de Platón. Con el destierro de la emoción y el arte reducido a "la imitación y habilidad para", resulta determinante adelantar un giro copernicano que haga aduana a la actual concepción platónica del arte y recupere su condición plural.

Concebido, además, como "apariencia" y no como "esencia", el arte proviene de algo distinto de la razón, por lo que resulta ser irracional, en consecuencia, el arte, según Platón, pretende construir "apariencias" que engañan. Si el artista "construye apariencias" todas sus obras no son más que artefactos extraños, banales y peligrosos que provocan el colapso de las facultades racionales. Puesta en tela de juicio la razón, los poetas deben ser expulsados de La República de Platón y por ende de la educación. Llegado este punto, creemos necesario profundizar respecto a la posición platónica sobre: el arte, la razón y la emoción.

Lejos de ser modernos, los temas relacionados con la estética como el arte y la poesía han sido tema de encuentros y desencuentros desde la antigua Grecia. Con objetivos tendientes al placer como lo sostuvo Demócrito hasta la opinión socrática en la que las bocetos humanos, no solo representan su cuerpo, sino además, el alma, estableciendo por primera vez el concepto de belleza espiritual, contrariamente al de belleza física que había defendido hasta entonces la filosofía griega.

Con el mundo entendido como imagen, con la filosofía influida muchas veces por los residuos metafísicos de una larga tradición, con el conocimiento dependiendo de la experiencia y la verdad de los sentidos, las resonancias de estas concepciones no solo abarcan la historia de la filosofía, sino, además, la historia del arte. De ahí la desilusión y el desencanto al poner al descubierto la banalidad de las cosas y especialmente de la percepción del arte presente 
en la tragedia griega como imitación de acuerdo con Platón, en la medida que los poetas y dramaturgos, son hombres vulgares e injustos que forjan falsas narraciones.

Nos falta ahora examinar la tragedia de Homero, que es su padre. [...] Los poetas trágicos están muy versados en todas las artes, en todas las ciencias humanas que tienen por objeto el vicio y la virtud, [...] debemos averiguar si los que hablan de esta manera se han dejado engañar por esta clase de imitadores, si su error procede de que, al ver las producciones de estos poetas, han olvidado que están tres grados distantes de la realidad y que, sin conocer la verdad, es fácil acertar con esta clase de obras que, en último término, no son más que fantasmas que no tienen ninguna realidad (pp. 324).

No solo la educación, sino además, el arte, tuvieron la peor parte con la aparición de la escritura alfabética en la época de Platón. Degenerada y al servicio de la política, la educación dejó de ser el espacio en el que el maestro lleva a su discípulo a explorar, avanzar y descubrir conocimientos a través de la mayéutica como lo hiciera el Sócrates idealizado por la tradición y pasó a ser una máquina comprometida con el modelo de sociedad en la que emoción y arte, debían ser expulsados de la Polis en general y la educación en particular.

El arte se entiende como "destreza" o "habilidad", tanto en el terreno material como en el intelectual. Con capacidades miméticas, el artista imitaría a través de sus imágenes los objetos reales, que lejos de pertenecer al mundo de las ideas solo se limitaría a representarlas falsamente. Por su carácter imitativo, las creaciones artísticas de acuerdo con Platón, no solo

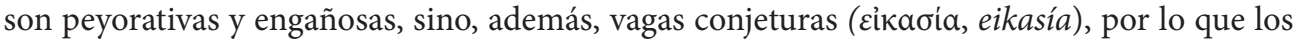
artistas son "pseudoartífices", por la inautenticidad de su habilidad. Leemos en La República:

[...] lo mismo que dijimos, el pintor, hará un retrato de un zapatero, aunque ningún conocimiento tenga de este oficio, con un parecido tal que los ignorantes, engañados por el dibujo y por el colorido, creerán ver un verdadero zapatero. De la misma forma, el poeta, sin otro talento que el de imitar, sabe con un barniz de palabras y de expresiones figuradas, dar también a cada arte los colores que le convienen [...], el autor de fantasmas, es decir, el imitador, solo conoce la apariencia de los objetos, de ninguna manera lo que tiene es real (pp. 324).

Reflexionada la "obra de Arte" a partir de la dialéctica entre las "apariencias" y las "esencias", la posición platónica le asigna, además, la categoría más alejada de la "realidad", es decir, el tercer grado en función de la "Verdad" (aletheia).

Ahora bien, ¿te parece que difiere en algo de este el que, tanto en lo relativo a la pintura o música como a la política, llama ciencia al haberse aprendido el temperamento y los gustos de una heterogénea multitud congregada? Porque, si una persona se presenta a ellos para someter a su juicio una poesía o cualquier otra obra de arte o algo útil para la ciudad, haciéndose así dependiente del vulgo en grado mayor que el estrictamente indispensable, la llamada necesidad diomedea le forzará a hacer lo que ellos hayan 
de alabar. ¿Y has oído alguna vez a alguno que dé alguna razón que no sea ridícula para demostrar que realmente son buenas y bellas esas cosas? -Ni espero oírlo nunca, dijo- (pp. 208).

Resulta determinante recuperar el protagonismo del arte, rescatarlo del oscuro lugar de elucubraciones, verdades e ideales que le arrebatan su poder de reflexión, su naturaleza ambigua, emocionante, enigmática, equívoca, indeterminada, desmaterializada, sin espacio ni tiempo preciso.

En síntesis, la educación curricular y la concepción de arte, están fundadas en una concepción equivocada de la antropología, es decir un error platónico, cuando el discípulo de Sócrates deslinda el alma del cuerpo, la razón de los sentidos, el pensamiento del lenguaje, la verdad de la opinión, dualismos vigentes durante siglos en Occidente bajo el auspicio de la filosofía con la complicidad de la educación.

\subsection{Hay placeres falsos (Filebo)}

Lo fantástico del interés científico por la comprensión de los mecanismos neuropsicológicos que intervienen en la emociones, ha permitido, desde inicios del siglo XXI, identificar las diferencias entre emociones y sentimientos. Esta distinción (entre emociones y sentimientos) es posible rastrearla en todos los textos de Damasio, específicamente en El error de Descartes:

¿Qué es un sentimiento? ¿Por qué no empleo de forma intercambiable los términos "emoción" y sentimiento"? Una razón es que aunque algunos sentimientos están relacionados con las emociones, muchos no lo están: todas las emociones generan sentimientos si uno está despierto y alerta, pero no todos los sentimientos se originan en las emociones. Llamo sentimientos de fondo a los que no se originan en las emociones [...] se originan en estados corporales "de fondo" y no en estados emocionales. [...] Un sentimiento de fondo no es lo que sentimos cuando saltamos de pura alegría, o cuando nos encontramos abatidos por el amor perdido; estas dos acciones corresponden a estados corporales emocionales (Damasio, 1994, pp. 172180).

En esas condiciones, mientras las emociones, de acuerdo con Damasio, son a corto plazo, los sentimientos serían emociones estables, por lo tanto, a mediano o largo plazo. A diferencia del instinto que ofrece respuestas dicotómicas a los desafíos del entorno y a las necesidades del organismo, la emoción ofrece respuestas susceptibles de graduación en las que juega un papel capital el sistema límbico y en particular, la amígdala cerebral. Aunque el instinto y la emoción pueden ser objeto de racionalización, no es necesario que ello ocurra. En principio, el instinto y la emoción son autónomos.

A diferencia de las emociones, los sentimientos interactúan con el pensamiento y ganan la estabilidad que falta en las primeras. Aunque más longevo que las emociones, la duración de los sentimientos está determinada por el tiempo en que se esté pensando en ello (razonando). 
En palabras de Damasio:

Cuando experimentas una emoción, por ejemplo la emoción de miedo, hay un estímulo que tiene la capacidad de desencadenar una reacción automática. Y esta reacción, por supuesto, empieza en el cerebro, pero luego pasa a reflejarse en el cuerpo, ya sea en el cuerpo real o en nuestra simulación interna del cuerpo. Y entonces tenemos la posibilidad de proyectar esa reacción concreta con varias ideas que se relacionan con esas reacciones y con el objeto que ha causado la reacción. Cuando percibimos todo eso es cuando tenemos un sentimiento (http://books.google.com.co).

Si para las emociones es suficiente la intervención del sistema límbico (LeDoux), los sentimientos, en cambio, demandan la intervención del pensamiento. Los sentimientos son emociones estabilizadas. A diferencias del pensamiento que se ocupa de lo posible, la emoción, en cambio, es un hecho real. Pueden existir falsas expectativas pero no falsas emociones. El dualismo verdad-falsedad, no aplica a la emoción. No hay emociones falsas. Al no depender tampoco del neocortex sino del instinto, diríamos también que no hay placeres falsos.

Sin embargo, para Platón, existen unos placeres verdaderos, que lejos de ser percibidos por los sentidos (mundo sensible), no solo son originados, sino, además apreciados solo a través de la inteligencia (mundo de las ideas). Aunque el placer y la alegría, no hayan sido habitual

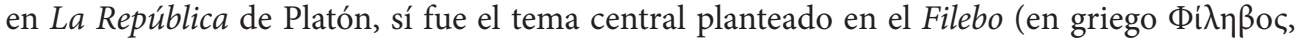
en latín: Philebus), uno de los últimos diálogos platónicos, en el que Sócrates aparece como protagonista y cuyo tema central gira en torno al rol del placer y la inteligencia en la vida conducida por el bien.

Posiblemente posterior al Parménides, al Sofista y al Político, este escrito expone la crítica platónica al placer cuando se aleja de la de Filebo, uno de sus personajes, que señala el placer como prerrequisito para la felicidad humana. Protarco, personaje adoptado por Platón, para exponer sus ideas, sostiene que la realidad de los deseos no dependería de su magnitud, ni de su vitalidad, sino, de su pureza, aunque aclara, que no hay deseos por puros que sean que estén por encima del bien, porque el bien se basta a sí mismo. Leemos en el Filebo:

PROTARCO. [...] Nos has concedido esta entrevista, Sócrates, y te has entregado a nosotros, para descubrir juntos cuál es el más excelente de los bienes humanos. Habiendo dicho Filebo que es el placer, la alegría, el goce, has sostenido tú, por el contrario, que los mejores bienes no son estos, sino los otros, cuyo recuerdo se repite en nosotros [...]. Decías, pues, [...] que la inteligencia, la ciencia, la prudencia, el arte, son un bien de un orden superior al placer, y que es preciso trabajar para adquirir todos los bienes de este género, y no los otros. [...] SÓCRATES. Ahora que hemos separado ya suficientemente los placeres puros y los que con razón pueden llamarse impuros, añadamos a esta reflexión, que los placeres violentos son desmedidos, y que los otros, por el contrario, son comedidos. Digamos también que los primeros, que son grandes y fuertes, y se hacen sentir, ya muchas, ya raras veces, pertenecen a la especie del infinito, que obra con más o menos vivacidad sobre el cuerpo y sobre el 
alma; y que los segundos son de la especie finita (pp. 37, 109).

Esta idea platónica tendría su origen en la división alma-cuerpo, que no solo decretó la existencia de conocimientos puros, sino además, lo que es todavía más increíble de placeres puros. Con el giro lingüístico sabemos que no hay pensamientos puros, con los aportes de Damasio sabemos que no hay placeres puros y desde Freud sabemos que el principio de placer remite al instinto. Aunque los tres cerebros (MacLean) se ocupen de funciones específicas, no menos cierto es que funcionan como uno, lo que no nos permitiría hablar de conocimientos puros ni de placeres puros. Si la razón fuera autosuficiente, nadie hablaría del déficit motivacional de las éticas cognoscitivas.

Clasificados por Platón los deseos en puros e impuros, los primeros tendrían el primerísimo lugar en detrimento de los últimos. Los deseos impuros con características finitas y restringidas, resultan ser enemigos de la felicidad y de la razón, por lo que deben ser desterrados y evitar su mezcla con los placeres puros propios de la ciencia. Que la felicidad no solo dependa del placer, da cuenta Platón al concluir que la ciencia aunque influye más en la felicidad por su pureza, durabilidad y cercanía al bien, necesita ser combinada con el placer (pero solo aquellos placeres puros, medidos y verdaderos) para alcanzar la felicidad.

Platón se escuda en Sócrates nuevamente para justificar la primacía de la inteligencia, la sabiduría y la memoria, como prerrequisitos para la vida buena, en detrimento de la falsedad y la malicia del placer, del gozo y del disfrute. Que el placer sea limitado para su conservación, que la sabiduría sea autosuficiente, sería otra evidencia no solo del maniqueísmo platónico, sino, además, del temor a lo que desata.

SÓCRATES. En efecto, la diosa misma, mi buen Filebo, fijando su atención en el libertinaje y en la intemperancia de todos géneros, y viendo que los hombres no ponen ningún límite a los placeres y a la realización de sus deseos, ha hecho que penetraran en ellos la ley y el orden, que son del género finito. Tú pretendes que limitar el placer es destruirlo, y yo sostengo, por el contrario, que es conservarlo [...]. Que la sabiduría no entre para nada en la vida del placer, ni el placer en la vida de la sabiduría. Porque si uno de los dos es el bien, es preciso que no haya absolutamente necesidad de nada más, y si uno o el otro nos parece necesitar otra cosa, no es ya el verdadero bien que buscamos (pp. 34 - 37).

En contraposición a la antropología platónica, el mundo intelectual sin motivación provoca la apatía, no hay acción. La categoría de falsedad lejos de aplicarse a la vida, se aplicaría a las ideas. Esta clasificación platónica de placeres falsos y placeres verdaderos, evidencia el maniqueísmo y la colonización del instituto por el intelecto. A los placeres fugaces les aplica la categoría de falsedad y a los que él cree estables la de veracidad.

De la misma forma que lo representó en La República, después de pasar por varias clasificaciones, entre otras, placeres puros e impuros, verdaderos y falsos y tipos de conocimiento, Filebo concluye que lo bueno de la vida mixta es la fórmula o la proporción con la que se mezclan 
estos componentes, y de nuevo esta procedería de la inteligencia, no del placer. El maniqueísmo platonicomoral laboriosamente construido se hace evidente cuando sataniza el placer, lo ahoga con el dualismo cuerpo- alma para negar su validez.

A la actual sociedad, pudiéramos conjeturar, que la atormentaría el monstruoso arquetipo moral ideado por Platón, en el que lejos de ser protagonista, el placer es convertido en enemigo de la razón, promoviendo la intolerancia y la frustración (Freud), de un lado, y el déficit motivacional de las éticas cognoscitivas del que tanto se lamentan los intelectuales, del otro lado.

Platón aplica categorías de la vida intelectual al mundo de la vida emocional, eso no es otra cosa que racionalismo. Para la razón la verdad es lo permanente y el error el cambio. Pensar que hay placeres permanentes y que si cambian son falsos, son ideas platónicas que niegan la naturaleza humana.

Tanto en La República como en el Filebo, Platón conspira e implanta una doctrina fundamental que podría caracterizarse: la educación al servicio de la política, la defensa de las exclusiones sociales y la condena a todo aquello que emocione o brinde placer. El lenguaje, alrededor del cual gira el sistema educativo queda relegado a la razón y despojado de sus condiciones relativas y neutrales.

Habiéndose enemistado con los poetas, después de repudiar la retórica, Platón reconoce en la dialéctica la forma de expresión propia del discurso filosófico. Al potenciar las emociones los recursos retóricos estarían en condiciones de sobornar el intelecto y por eso mismo resultan engañosos en palabras de Platón. Más radical todavía fue Aristóteles quien no solo opone la retórica a la dialéctica, sino, además, la lógica. Para tal fin compromete a las palabras con una especie de sentido propio, lo que constituye un anticipo de lo que siglos después se conocería como estilo plano.

Al someter la educación a un pensamiento único y el lenguaje a la lógica, se crean las condiciones para la desconexión emoción-razón, crisis silenciosa que nos hace cada vez más infelices e intolerantes. Así como Platón postula la existencia del modelo, Aristóteles hace lo propio con el fin (telos). Que el maestro mire hacia arriba y el discípulo hacia abajo como lo señala el afamado cuadro de Rafael en la escuela de Atenas, no debe llamarnos a engaño. Se trata de filosofías universalistas y esencialistas en las que las afinidades pesaban más que las diferencias.

\subsection{Implicaciones educativas}

Esa larga historia en la que la emoción es expulsada, la misma que va de Platón al positivismo reafirmando la vigencia del pensamiento único, ha tenido en la academia su más acucioso acólito. Apostar por el pluralismo es una tarea pendiente. De allí que deba repensarse la educación con fines políticos, la idea de justicia y muy en particular, el deslinde de la emoción de la razón. Lejos de ser fenómenos naturales, el pensamiento único, el totalitarismo político y 
la educación confesional son propios de Occidente. Es necesario abrir paso a otras formas de acceder al conocimiento de cara a las trasformaciones sociales.

Cuando se habla hoy día de educación repetitiva y reproductora, es evidente que el paradigma en cuestión remite a Platón. Exenta de emociones, la educación no tiene más opción que repetir para grabar el mensaje. Habiendo postulado la existencia de modelos ideales (que Aristóteles anticipa a descalificar como metáforas poéticas), la educación se reduce a una especie de copiar y pegar.

\subsection{Aristóteles, títere de la gramática}

Mientras que la filosofía platónica es heredera del orfismo y la educación es puesta al servicio de la política, la filosofía aristotélica no deja de estar influida por su condición inicial de biólogo. De allí que el estagirita sea al mismo tiempo, el padre de la biología y de la lógica. Al igual que su maestro Platón, Aristóteles ejerció una enorme influencia sobre la historia intelectual de Occidente. A este filósofo, biólogo de la antigua Grecia le debemos entre otras cosas, buena parte del léxico de la metafísica, incluidos muchos de sus dualismos más característicos como materia y forma, las taxonomías y el principio de no contradicción. Aristóteles vió sustancias donde no había más que procesos, y fines, donde lo real era la contingencia. Las filosofías de la historia son herederas del telos aristotélico y han legitimado numerosos regímenes totalitarios que se dicen estar a tono con el fin de la historia. Uno tras otro han sido refutados por los hechos.

Desde Aristóteles, la teoría de las ideas fue controvertida de manera radical. Para el estagirita, el mundo de las ideas no era más que una metáfora platónica. Sin embargo, la división sensibleinteligible conservó su vigencia. Así como Platón clasificó el alma en irascible, concupiscible y racional, Aristóteles la divide en racional, sensitiva y apetitiva, en lo que es posible identificar un indiscutible paralelismo. La repercusión de dichas taxonomías en el plano educativo, se hacen evidentes cuando los filósofos, con el uso del lenguaje terminan encontrando: los sustantivos en cosas y los verbos en fines.

A pesar de los avances científicos y filosóficos gestados a partir del siglo XVI, por Copérnico, Galileo y Newton, de una parte, y por Nietzsche, de otra parte, en los que se han puesto en tela de juicio los postulados aristotélicos, la sociedad en general, y la academia en particular, continúan siendo gobernadas por sus taxonomías, prueba de ello, no son solo las facultades, las especializaciones y la desconexión emoción- razón, sino, además, el uso del lenguaje por su veracidad (verdadero) y no por su utilidad (Nietzsche).

Lejos de reducirse al lenguaje, la razón, en Aristóteles, remite a la lógica. En De la interpretación, el discípulo de Platón, insiste en la existencia de un mundo real del cual da cuenta el pensamiento y se expresa en el lenguaje. El lenguaje no pretende contaminar el pensamiento con las particularidades lingüísticas (léase usos desviados del lenguaje recopilados por la retórica), por eso, debe ser simple y plano. La idea de pensamiento puro, en síntesis, fue la que sustentó el universalismo durante siglos. 
Aristóteles propone evitar cualquier tipo de contacto de conceptos y definiciones con la retórica, y en particular con la metáfora en virtud de su capacidad para confundir. La naturaleza busca la conservación de los seres vivos y ha dotado según Aristóteles, a los animales del instinto y al hombre de la razón. Las emociones, desde su concepción sustitucioncita de la metáfora, carecen de valor cognoscitivo y funcionalidad, son oposiciones a la razón y perturbaciones del ánimo porque no poseen fuerza natural, son opiniones o comportamientos adoptados a la ligera, por lo tanto, las emociones y los sentimientos son fenómenos de ignorancia que dependen de la moral. Leemos en El arte de la retórica:

El hombre tiende naturalmente a la felicidad (eudaimonía) [...], por tanto [...] deberá saber qué es la felicidad y cuáles son sus partes [...], los hombres eligen o rechazan respectivamente lo que les acarrea la felicidad o los aparta de ella. No obstante, el conocimiento exhaustivo de esta materia pertenece a la moral (Aristóteles, 2005 p. 129).

Que Aristóteles conciba el ser como la sustancia (ousia), compuesta de materia y forma (mientras la última confiere individualidad a los seres, la primera, en cambio, opera como sustrato), no solo se debe al protagonismo alcanzado por el uso sintáctico del verbo ser en la escritura, sino, además, a su condición de naturalista.

De la interpretación, recoge las ideas aristotélicas sobre equivalencias del mundo, del pensamiento y del lenguaje lógico que podrían resumirse en: el logos (lenguaje) al ser lógico, puede decir la verdad; el cosmos (mundo) y la psique (pensamiento) comparten las mismas categorías, el lenguaje es la expresión pura del pensamiento y no lo contrario y el mayor interés del pensamiento es captar las regularidades del mundo. La primacía de lo inteligible sobre lo sensible no solo se afirma cuando se reconoce la primacía del pensamiento sobre el lenguaje, sino además, cuando en La metafísica, Aristóteles sostiene que la experiencia se ocuparía de lo particular y la ciencia de lo universal.

\subsubsection{El cosmos}

Que la oralidad a diferencia de la escritura no dé tiempo para pensar, es evidente en la cotidianidad. Por las connotaciones propias de la oralidad, en las que nada permanece, la vida del ser humano es gobernada por la contingencia y el cambio. Con la aparición de la escritura, esta disponibilidad al cambio es reemplazada por la idea de permanencia, bien con el idealismo platónico, en primera instancia; bien con el finalismo aristotélico, en segunda instancia.

Con la aparición de la escritura, viene la falsa idea de permanencia que nos hizo perder la pista del legendario Empédocles cuando postula la Teoría de las cuatro raíces, (agua de Tales de Mileto, el fuego de Heráclito, el aire de Anaxímenes y la tierra de Jenófanes) de acuerdo con la cual la multiplicidad del cosmos se da en la interacción de estas raíces (elementos de acuerdo con Aristóteles) con el amor y el odio en fases ascendentes y descendentes. 
Concebido el mundo como un espacio lleno de objetos con atributos particulares, en los que el principio de no-contradicción refuerza la idea del uso copulativo del verbo ser cuando suprime la posibilidad de ser o no ser al mismo tiempo, se hace evidente el relevo de la oralidad por la escritura, es decir, de lo que se escucha por lo que se ve en la medida en que a cada objeto corresponde un lugar y a cada lugar un objeto.

[...] Es evidente que uno de los dos dice necesariamente la verdad, si toda afirmación es verdadera o falsa: pues en las cosas de ese tipo no se darán ambas a la vez. En efecto, si es verdad decir que es blanco o que no es blanco, necesariamente será blanco o no será blanco y, si es blanco o no es blanco, será verdad afirmarlo o negarlo; y, si no se da, se dice una falsedad y, si se dice una falsedad, no se da; así que necesariamente la afirmación o la negación ha de ser verdadera [...]. Así, pues, es necesario que lo que es, cuando es, sea, y que lo que no es, cuando no es, no sea; sin embargo, no es necesario ni que todo lo que es sea ni que todo lo que no es no sea: pues no es lo mismo que todo lo que es, cuando es, sea necesariamente y el ser por necesidad sin más; de manera semejante también en el caso de lo que no es (http://www.philosophia.cl).

El principio de no-contradicción acreditado por Aristóteles, gesta la exclusión de un tercero en detrimento de la ambigüedad propia del ser humano. En adelante, todo aquello que se contradice, es decir, lo que es mezcla, ambigüedad o abre otras opciones de sentido, sería propio de los retóricos.

\subsubsection{Materia y forma}

Como dualidad central de la metafísica, la oposición sensible-inteligible es rica en desarrollos; el más importante, quizá, en la obra de Aristóteles es la dualidad materia-forma.

Después de concebir el ser como sustancia, es decir, como lo que es (la sustancia primera, el sustrato o esencia, en lo particular o individual; la sustancia segunda, el universal, en el género o especie). Mientras la sustancia segunda es simplemente forma, la sustancia primera, se descompone en materia y forma.

\subsubsection{El alma}

El hombre como todos los seres vivos, está compuesto de cuerpo y alma. El cuerpo representa la materia que no cambia, el alma representa la forma esencial que cambia en lo adjetivo pero no lo sustantivo. De la misma forma que lo hizo su maestro, Aristóteles, sostiene la existencia de dos partes del alma, una racional y una no-racional, en la parte no-racional identifica una facultad "común y vegetativa causa de la nutrición y el crecimiento" y una facultad apetitiva (o desiderativa).

En síntesis el alma, de acuerdo con Aristóteles se divide en tres: racional (razón), sensorial (sentidos), y apetitiva (deseos). El alma racional es espiritual e inmortal. Las almas sensorial y apetitiva, son irracionales, corporales y mortales. Forma y materia fueron principios 
trasladados al lenguaje y que constituyeron el principio de la metafísica como lo veremos a continuación:

\subsubsection{El lenguaje}

Si conocer el ser es conocer la ousia, de acuerdo con Aristóteles, si la ousia en español es sustancia o esencia, es decir, materia mas forma, el lenguaje debe ocuparse de esencias y universales. Que en las lenguas indoeuropeas la oración gramatical gire alrededor del nombre común (sustantivo), lo que permanece y no cambia, de un lado, lo que tienen en común los diferentes objetos denominados con esa palabra, la mayoría de las veces, estaría en concordancia con el primado de la sustancia. Que al hablar de lo "sustantivo" estemos haciendo referencia a lo principal, y al hablar de lo "adjetivo", a lo secundario, refuerza la idea en cuestión.

Que la lógica se erija en el arte del pensar correctamente, obligaría al lenguaje a cumplir con sus preceptos a riesgo de degenerar en retórica si no lo hace. El tratamiento lógico del lenguaje expresado en conceptos universales, juicios que afirman o niegan y silogismos que son resultado obligado de sus premisas nos llevan no solo a ignorar lo relativo a lo imprevisto y provisional de lo humano, sino, además, con características excluyentes, la gramática lingüística de acuerdo con Aristóteles, se limitaría a la frase célebre de Shakespeare "ser o no ser", de ahí la cuestión. Leemos en De la interpretación:

Puesto que, de las cosas, unas son universales y otras singulares - llamo universal a lo que es natural que se predique sobre varias cosas y singular a lo que no, v.g.: hombre es de las <cosas > universales y Calias de las singulares-, necesariamente hay que aseverar que algo se da o no, unas veces en alguno de los universales, otras veces en alguno de los singulares (http://www.philosophia.cl).

A diferencia de Platón que somete el hombre al ideal a través de la razón sin atenuante alguno, Aristóteles en cambio, reconoce el valor de la eudaimonía, y aunque concibe la contemplación intelectual como la dicha suprema, no desconoce la importancia de otros bienes que remiten a la cotidianidad y al contexto. Las emociones no serían ajenas al universalismo aristotélico planteado entre otros por el lenguaje, cuando propone la administración de nuestros deseos y pasiones a través de la razón. Proveernos de satisfacción "justa”, facilitaría una vida sin extremos, ésta moderación, de acuerdo con Aristóteles, constituye la máxima ambición del hombre que aspira a la más alta de las virtudes del ser humano, es decir, a la sabiduría. Continuamos con De la interpretación:

[...] Origina la distracción de los espíritus el proponer a los discípulos diversas materias al mismo tiempo. Como hacer estudiar en el mismo año Gramática, Retórica, Dialéctica y hasta Poesía [...]. Los preceptos referentes a las lenguas deben ser gramaticales, no filosóficos. [...] La gramática infantil debe consistir en hablar rectamente la lengua materna; esto es, pronunciar clara y distintamente las letras, sílabas y palabras (https://docs.google.com). 
El sueño aristotélico de construir un lenguaje neutral, universal, racional y común a todas las lenguas, es un pensamiento universalista que terminó haciendo carrera, entre otros, por Comenio en su Didáctica Magna, el mismo que abastece la academia actual, teniendo como materia prima, la razón y el lenguaje como instrumentos libres de contexto e interacciones.

\subsection{La metáfora y el lenguaje}

La misma deformación lingüística de la gramática y de la concepción invariante de hombre y sus hábitos intelectuales fue sufrida por figuras retóricas como la metáfora. Despojada de su capacidad para ampliar horizontes de sentido y emocionar, la metáfora fue reducida, no solo al traslado de sentido, sino, además a lo meramente ornamental. Leemos en Poética de Aristóteles:

La metáfora es la trasposición del nombre de una cosa a otra [...]. En efecto [...] las metáforas, los términos ornamentales, impedirán al lenguaje tornarse vulgar y prosaico, mientras que los vocablos corrientes le asegurarán la requerida claridad. [...] El empleo demasiado aparente de este modo de expresión, cualquiera que sea, producirá un efecto ridículo, y es necesario que la mesura caracterice a cada una de las partes de la elocución; pues, en efecto, si se hace un uso inoportuno de las metáforas [...] el poeta logrará el resultado que tendría si lo hiciera para producir un efecto ridículo (Aristóteles, 1988, pp. 79 - 84).

Que nuestro lenguaje cotidiano sea en gran medida metafórico, que la metáfora nos permita acercar conceptos lejanos, es decir, estructurar conceptos a partir de otros, es un hallazgo que Aristóteles siempre ignoró o por lo menos negó. Que la experiencia física y cultural, sean la base sobre la que se construyen los conceptos y sus manifestaciones lingüísticas como lo sostienen Lakoff y Johnson, parecen ser comprensiones que brillan por su ausencia en la concepción aristotélica sobre la metáfora. Leemos en Metáforas de la vida cotidiana:

Para la mayoría de la gente, la metáfora es un recurso de la imaginación poética, y los ademanes retóricos, una cuestión de lenguaje extraordinario más que ordinario. Es más, la metáfora se contempla característicamente como un rasgo solo del lenguaje, cosa de palabras más que de pensamiento o acción. Por esta razón, la mayoría de la gente piensa que pueden arreglárselas perfectamente sin metáforas. Nosotros hemos llegado a la conclusión de que la metáfora, por el contrario, impregna la vida cotidiana, no solamente el lenguaje, sino también el pensamiento y la acción. Nuestro sistema conceptual ordinario, en términos del cual pensamos y actuamos, es fundamentalmente de naturaleza metafórica (Lakoff y Johnson, 1998, pp. 39).

En cuanto al estagirita, es evidente la contraposición. Leemos en la Poética de Aristóteles "entiendo por palabras extrañas [...] la metáfora, las palabras alargadas y de una manera general, todas aquellas que están por fuera del uso cotidiano” (pp. 82). 


\subsection{Implicaciones educativas}

Los mapas conceptuales y los programas curriculares son estrategias pedagógicas actuales y ejemplos prototípicos que comprueban el legado de la taxonomía aristotélica. Con propiedades omnipotentes estas estrategias pedagógicas nos hacen ciegos frente a la emoción porque su lógica clasificatoria solo se puede utilizar en cosas que no cambian, no en la pluralidad humana. Considerado como una característica esencial de la especie humana, que la distingue de las animales (Política), el lenguaje es despojado de su capacidad para movilizar y producir pensamiento, y queda relegado a su mera representación, como se evidencia en Poética.

[...] Respecto al pensamiento podemos asumir lo que se ha dicho de él en nuestro tratado de la Retórica, pues aquél pertenece más bien a este sector de la investigación. El pensamiento incluye todos los efectos que deben ser producidos por medio del lenguaje; entre estos están la prueba o la refutación, la exaltación de la emoción (piedad, temor, ira, etc.) Aristóteles. Cap XIX. (http://coral.ufsm.br).

Preparar al estudiante para la instrucción y el lenguaje universal, era el objetivo aristotélico, el mismo que subyace en De la interpretación. Lejos de otorgar protagonismo a la pluralidad que representa el lenguaje, el análisis de su uso en la producción de conocimiento y en el discurso racional, se llevaría el primerísimo lugar.

\subsection{Juan Amós Comenio, universalismo hecho didáctica}

Con la educación al servicio de la política, dado el absolutismo de la razón y la reducción de la palabra al concepto, la pedagogía no sería ajena al complot. Comenio, teólogo, filósofo y pedagogo del siglo XV, llamado padre de la pedagogía, haría sus aportes a la educación de los siglos XVI y XVII. Aunque logró vislumbrar en la educación, el escenario por excelencia para el desarrollo personal y social, en general, y la enseñanza de las lenguas con fines comunicativos, no como conocimiento, en particular, vendió ideas sobre una educación universal con taxonomías y jerarquías, tal y como lo hicieron Platón y Aristóteles, aunque haya intentado alejarse de su pensamiento filosófico.

Comenio logró sentar en Didáctica Magna, una de las obras pedagógicas más importantes de los últimos siglos, su idea sobre un método perfecto para todos. En esta obra, la educación es el escenario propicio para la conjugación de una serie de ideas religiosas y virtudes morales que llevan a la salvación y a la bienaventuranza eterna. Con la pedagogía Pansófica (educación para todos y para todas las cosas), al servicio del dominio de las pasiones (gobierno de la razón sobre la emoción) y la felicidad en el más allá, esta vida nos bastaría para cosechar la razón y la moral. Leemos en Didáctica Magna:

Vivimos aquí una vida triple: vegetativa, animal e intelectiva o espiritual, la primera de las cuales jamás se manifiesta fuera del cuerpo; la segunda se dirige a los objetos por las operaciones de los sentidos y movimientos; la tercera puede existir separadamente, 
como ocurre en los Ángeles. Es evidente que este supremo grado de la vida esté en nosotros oscurecido y como dificultado por los demás, y debemos suponer que ha de existir algo donde esta vida intelectiva alcance su mayor desarrollo (in deducatur) (Comenio, 1962, p. 28).

La sola idea de la Didáctica Magna presupone un hombre sin historia o una historia reducida al paso del tiempo a través de la cual el hombre permanece el mismo. La sola mutación de las tecnologías de la palabra ha refutado semejante pretensión. No es igual la enseñanza que cuenta con los recursos de internet que cuando debíamos peregrinar por las bibliotecas. No es lo mismo la oralidad que impacta que la escritura que organiza, ni el tratado que adoctrina al link que bifurca. De la misma forma que lo hicieron Platón y Aristóteles, Comenio apuesta por la razón en detrimento de la emoción (alegría) y por la búsqueda de la felicidad a través de la fe y la sabiduría:

[...] Dios [...] hizo el Paraíso para su delicia, [...]. Hay que entender que este deleite de que hablamos no es el del cuerpo [...], sino del alma [...]. Es aquello que dice el libro de la sabiduría: No tiene amarguras la conversación de la sabiduría, ni tedio el a ella dedicado, sino alegría y gozo [...]. El deleite en uno mismo es aquella dulcísima satisfacción que con su excelente disposición interior experimenta el hombre dado a la virtud al verse dispuesto a lo que exige la justicia. Esta alegría es mayor al principio conforme a aquello: la buena conciencia es un perpetuo banquete (pp. 25).

La Didáctica Magna fué la obra que le dió fama en Europa, las evidentes taxonomías allí contenidas, posiblemente hayan sido heredadas de Aristóteles y la educación con fines ya no políticos, sino, religiosos, habrían sido heredados de Platón. En el texto, propone un modelo de racionalidad instrumental, en donde un solo método funciona para todos. Formula, además, principios para educar, como la imitación (para nadar hay que imitar a los peces) y como pilares fundamentales de la educación propone el castigo, las normas y el temor a un Dios perfecto como única forma de acceder a los valores, la moral y al conocimiento, y ser feliz en consecuencia.

Con funciones específicas, el docente se limita a simplificar, preparar, organizar, ordenar y ser el modelo a seguir. Lo monótono de su modelo, desborda lo educativo y se hace extensivo a lo social. Que la educación sea el escenario propicio para perpetuar la fe, la salvación y la felicidad eterna, se hace evidente en el siguiente aparte:

Concebido y dado a luz vivió entre los hombres; después de muerto resucitó y subió a los cielos, y ya la muerte no le dominó más. [...] Arquetipo de los que han de ser reformados a la imagen de Dios (Rom. 8, 29). Y de igual modo que Él no vivió aquí, por estar, sino para, una vez terminada su misión, pasar a la mansión eterna, así también nosotros, consortes suyos, no hemos de permanecer aquí, sino que hemos de ser llevados a otra parte (pp. 30).

Desde Aristóteles, la razón nos diferencia de los animales. Asignado el papel protagónico a 
la razón, la educación entrena no para ser felices y avanzar, sino, para las letras, la virtud y la religión, inclusive, y así llegar a ser "útiles". La emoción queda relegada a la protección divina y su múltiple bendición aquí y en la eternidad. Ajena a la pluralidad humana, educar a todos a imagen y semejanza de Dios, constituye los fines de la educación. Leemos en Didáctica Magna:

[...] todos los que han nacido hombres lo fueron con el mismo fin principal, a saber para la que sean hombres; esto es, criaturas racionales. [...] Todos, han de ser preparados de tal modo que, instruidos sabiamente en las letras, la virtud y la religión, puedan atravesar útilmente esta vida presente y estar dignamente dispuestos para la futura. Dios, que quiere ser conocido, amado y alabado por todos aquellos en quienes se imprimió su imagen. [...] Ciertamente, con tanto mayor fervor se hará cuanto más viva estuviere la luz del conocimiento. Es decir, tanto amamos cuanto conocemos (pp. 71).

Educar para la obediencia voluntaria y con amor a Dios y a la iglesia, hace evidente el maniqueísmo religioso, así como la influencia de clasificaciones platónicas, y las taxonomías aristotélicas. No importa si las personas son felices o buenas, lo importante de acuerdo con Comenio es que sean sabias. Continuamos con Didáctica Magna:

Los ricos sin sabiduría, ¿qué son sino puercos hartos de salvado? [...]. Y el hermoso no educado, ¿qué es sino papagayo adornado de pluma o, como alguien dijo, vaina de oro que encierra arma de plomo? Los que alguna vez han de dominar a otros, como reyes, príncipes, magistrados, pastores de las iglesias y doctores, tan necesario es que estén imbuidos de sabiduría [...]. De igual modo los súbditos también deben estar ilustrados para saber prudente y sabiamente obedecer a los que mandan; no obligados de modo asnal, sino voluntariamente por amor (pp. 59).

Desconectada la emoción de la razón, la educación se limitaría a entrenar para los fines en detrimento de los medios. Este pensamiento metafísico en complicidad con la dialéctica platónica y la lógica aristotélica, haría de la educación actual la materia prima que asegura su supervivencia.

Luego no nos queda sino pensar que nuestro Creador tuvo a bien concedernos graciosamente, con deliberado propósito, al retardar el tiempo de la adolescencia, que fuese mayor el espacio destinado al ejercicio de nuestra educación y nos hizo durante tanto tiempo inhábiles para los cuidados económicos y políticos, a fin de que con ello nos hiciéramos más aptos para el tiempo restante de la vida (es decir, para la eternidad) (pp. 64).

Y para que estas facultades puedan ejercer diestramente sus funciones es necesario dotarlas claramente de aquellas cosas que iluminen el entendimiento, dirijan la voluntad y estimulen la conciencia, con lo que el entendimiento ahondará más, la voluntad elegirá sin error y la conciencia dirigirá todas las cosas hacia Dios. Del mismo modo que estas facultades (entendimiento, voluntad y conciencia) no pueden 
separarse porque constituyen el alma misma, así tampoco pueden estar desunidos los tres adornos del alma: erudición, virtud y piedad (Comenio, 1962, cap. 10).

Comenio construyó y potenció una serie de recursos pedagógicos que sentaron las bases de la racionalidad instrumental. De la misma forma que Skinner con su condicionamiento operante (refuerzos positivos y negativos), excluyó la espontaneidad de la emoción. Contrario a los avances en materia de neurociencia, gestados en las últimas décadas por Damasio, MacLean y LeDoux, que reconocen el poder de la emoción y la presencia de estructuras mentales (sistema límbico o emocional) que le son propias, Comenio consideraba la emoción antinatural y la imaginación únicamente sería el puente que conecta la ciencia con la memoria.

Para que el método excite el deseo de los estudios es necesario, en primer lugar, que sea natural. Lo que es natural marcha por su propio impulso. No hay que obligar al agua a que corra por la pendiente [...]. Tampoco el avecilla necesita hacerse rogar para salir volando en el momento de abrirle la jaula. [...] Se ejercitan en los niños: los sentidos en primer lugar (esto es fácil); después, la memoria; luego, el entendimiento, y por último, el juicio. Así, gradualmente, seguirán; porque la ciencia empieza por el sentido, y por la imaginación pasa a la memoria; después, por inducción de lo singular, se forma el entendimiento de lo universal, y por último, de las cosas suficientemente entendidas se compone el juicio para la certeza del conocimiento (Comenio, 1962, cap.17).

Mientras Comenio hace sus apuestas por la racionalidad instrumental, al servicio de la religión, Skinner apuesta por la modificación del comportamiento a través de refuerzos positivos y negativos según el caso, que en la medida de su eficacia dejan por fuera la autonomía del individuo y la espontaneidad de la conducta. En síntesis, ambos aportaron una serie de elementos conducentes, no solo a la reducción del individuo a la especie, sino, además, a la desconexión emoción-razón.

\subsection{El conductismo}

Considerado el individuo como un organismo que se adapta al medio (o ambiente), el enfoque conductista en psicología indagaría por la conducta de los organismos. Si algo distingue la historia es la bifurcación y en ese orden de idea el conductismo sería una especie de vuelta a la naturaleza en donde las cosas se repiten hasta el cansancio, a escala humana por lo menos. Cuando la sociedad, en general, y la universidad, en particular, asumen el modelo del panóptico, rinden culto al control, el mismo que fuera auspiciado por Skinner a través de los refuerzos negativos y positivos como lo hace conscientemente la universidad e inconscientemente la academia. Aunque el condicionamiento operante planteado por Skinner, es el que interesa especialmente al presente trabajo, para su mejor comprensión, haremos un rastreo general por el condicionamiento clásico de Iván Petróvich Pavlov y John Broadus Watson quienes sirvieron como fuente de inspiración, hasta centrarnos en el condicionamiento operante de Skinner. 


\subsubsection{Iván Petróvich Pavlov}

Fisiólogo ruso, conocido especialmente por la formulación de la ley del "Reflejo Condicionado" en la que la respuesta al estímulo podría ser una actividad psíquica o involuntaria. No obstante, al ocuparse de la fisiología, probablemente no sopesó las consecuencias que sus teorías tendrían en los ámbitos de la psicología y la pedagogía. En adelante, una tras otra, hicieron carrera las teorías que postulan el proceso de aprendizaje y del conocimiento como el resultado de reflejos condicionados. En síntesis, para aprender no es necesario pensar.

El Condicionamiento Clásico propuesto por Pavlov consiste en habilitar una serie de estímulos que eventualmente podrían provocar una respuesta refleja. El principio de asociación, radica en conectar estímulos que no necesariamente tienen relación entre sí. El estímulo, es un factor externo o interno capaz de provocar una reacción positiva o negativa en una célula u organismo. Sus experimentos, especialmente con animales (perros), lo llevaron a formular la hipótesis del "Reflejo Condicionado", en el que un "reflejo natural" o respuesta incondicionada (salivación) paso a ser una respuesta condicionada a través de un estímulo (la campana) que antes era un estímulo neutro (el animal no saliva por escuchar una campaña). Respuestas incondicionadas (RI), estímulos incondicionados (EI), y estímulos neutros (EN), hacen parte del léxico pavloviano, de clara estirpe maniqueísta. En términos generales, esta teoría busca:

1.Convertir un Estímulo Neutro (EN) en uno Estimulo Condicionado (EC).

2.Convertir un Estímulo Incondicionado (EI) (Reflejo Natural) en uno Estimulo Condicionado (EC).

3.Convertir una Respuesta Incondicionada (RI) en una Respuesta Condicionada (RC).

En conclusión, el Condicionamiento Clásico consiste en aprender una respuesta condicionada que involucra la construcción de una asociación entre un estímulo condicionado y un estímulo incondicionado. Al utilizarlos juntos, el estímulo condicionado que inicialmente (por naturaleza) era neutro, adopta las propiedades del estímulo no condicionado. Que la desconexión emoción-razón haga presencia en la academia, es la evidencia de que todavía percibimos a los estudiantes como individuos vacíos que adquieren conductas que pueden ser reforzadas, remplazadas o eliminadas. Pavlov, sentó las bases para el Condicionamiento Clásico, pero fué John Broadus Watson, quien lo desarrollaría.

\subsubsection{John Broadus Watson}

Watson, uno de los psicólogos estadounidenses más importante del siglo XX, sentó las bases de las teorías instrumentales del aprendizaje en su libro Inteligencia animal: Un estudio experimental de los procesos asociativos en los animales, fruto de su investigación doctoral. Watson, realiza el estudio de la conducta por medio de un método experimental, basándose 
en el paradigma estímulo-respuesta (E-R) de Pavlov. Del maniqueísmo psicológico y del protagonismo de las técnicas de modificación de conducta en detrimento de las emociones, da cuenta Watson en su más célebre expresión:

Dadme una docena de niños sanos, bien formados, para que los eduque, y yo me comprometo a elegir uno de ellos al azar y adiestrarlo para que se convierta en un especialista de cualquier tipo que yo pueda escoger -médico, abogado, artista, hombre de negocios e incluso mendigo o ladrón-prescindiendo de su talento, inclinaciones, tendencias, aptitudes, vocaciones y raza de sus antepasados (http://es.wikipedia.org).

Watson no solo brinda protagonismo a las conductas observables y niega existencia de la mente como entidad autónoma, sino que, además, adopta los principios del Condicionamiento Clásico (E-R) implementado por Pavlov para los animales y los extiende al aprendizaje humano a través del "Hábito" que se construye con el Estímulo-Respuesta (E-R) pavliano.

Las tres categorías de los hábitos en la personalidad propuesta por Watson: manuales (coger y manipular objetos, caminar, etc.), verbales (hábitos propios del lenguaje y pensamiento) y emocionales (emociones básicas: el miedo, la ira y el amor), dan cuenta del conductismo watsoniano en el que es posible medir la conducta a través de los tests psicológicos y modificar el comportamiento mediante la provisión de estímulos adecuados para tal fin. El controvertido experimento con un niño de once meses de edad (el pequeño Albert), sería prueba de ello. Con las reacciones del pequeño Albert, Watson pretendía demostrar dos aspectos fundamentales:

1. Que los principios del Condicionamiento Clásico, recientemente descubierto por Iván Pavlov, podían aplicarse en la reacción de miedo de un niño ante un objeto determinado (rata blanca, máscaras, objetos abundantes en cerdas).

2. Que con la simultaneidad de dos estímulos se construyen nuevas relaciones y dependencias entre sí, que generan a su vez, cambios orgánicos y/o conductuales.

Que algunos "reflejos" y reacciones emocionales de miedo, ira y amor tengan origen natural, haría que los demás comportamientos se adquieran, de acuerdo con Watson, mediante la asociación estímulo-respuesta. En el ya mencionado experimento con el pequeño Albert, Watson, probó que la respuesta incondicionada (RI) que luego condicionó (RC), puede ser nuevamente incondicionada (RI), demostrando así el papel fantasmagórico del lenguaje, y en cierta medida, de la razón.

Reducido el lenguaje a simples "hábitos de laringe", bastaría el condicionamiento o asociación de un objeto con su nombre para evocar la misma respuesta en todos los niños. En la educación, tanto el currículo como la enseñanza deben ser cuidadosamente programados y fundamentados en una serie de fases inmóviles y comunes: la formulación de objetivos terminales, la secuenciación de la materia, el análisis de las tareas y la evaluación del programa en función de los objetivos propuestos. 
Aunque Watson se ocupa del condicionamiento clásico y Skinner del condicionamiento operante, coinciden en su percepción sobre las emociones. Watson distingue tres emociones básicas: el miedo, la ira y el amor, y las define como simples reacciones corporales a estímulos específicos en las que la experiencia consciente no es un componente esencial. Para Skinner, en cambio, la emoción es "un estado articular de fuerza o debilidad de una o más respuestas, inducido por cualquier operación de una clase determinada” (Skinner, 1981, p. 195).

\subsubsection{Burrhus Frederic Skinner}

Para muchos, el padre de la educación en el siglo XX, quien propuso entre otras teorías, la que permite mejorar la sociedad e incrementar la felicidad humana, a partir de una especie de ingeniería social conducente a la modificación del comportamiento por medio del condicionamiento operante o instrumental que premia la conducta humana que la educación considera "adecuadas", al tiempo que adopta el castigo, por su efectividad, para eliminar las conductas no deseadas.

Entiende el lenguaje a partir de relaciones de palabras con objetos y realidades observables del mundo físico sin que haya que recurrir a factores explicativos basados en representaciones y variables mentales internas. Finalmente, Skinner es reconocido por sus destrezas mayéuticas, adoptadas por muchos hasta nuestros días.

Lejos de considerar el conocimiento como una construcción subjetiva, sin realidades absolutas, sino relativas y producto de la interacción del ser humano con su medio, Platón, Aristóteles, Comenio y Skinner coinciden en sus apuestas por el universalismo, las taxonomías y el ser humano único.

Acolitadas por Comenio, Descartes y Skinner, manipuladas por el pensamiento único, ajenas a las profundas trasformaciones de los procesos educativos, además, contingentes, la academia continúa utilizando taxonomías y estrategias estacionarias, represoras, excluyentes, bancarias y especialmente cómodas y "seguras" para los docentes.

\subsection{Sobre el conductismo}

Siendo Watson, el primero en hablar de la inexistencia de experiencias internas o emociones, por la imposibilidad de observarlas, dejó un legado que posteriormente, su discípulo Skinner, perfeccionaría. Si los procedimientos, de acuerdo con Watson, son objetivos, los experimentos diseñados y efectuados en un laboratorio, arrojarían resultados confiables, y aunque hechos inicialmente con animales, se harían extensivas al hombre en la medida que la respuesta depende solo del estímulo. En síntesis, para que hombres y animales reaccionen de la misma forma, solo en necesario un mismo estímulo, de acuerdo con Watson. Sin una racionalidad que nos diferencie de los animales como lo sostuvo Aristóteles, con la emoción por fuera de la vida humana, uno tras otro, los modelos pedagógicos (algunos tradicionales) centrados en la enseñanza repetitiva y bancaria (Freire), justificaron su existencia. 
Sometido a procesos estandarizados, cerrados, controlados y aislados del entorno, el proceso de aprendizaje queda a merced de los estímulos. El conductismo, una de las revoluciones psicológicas más influyentes, la misma que rechaza la conciencia, la mente y el lenguaje y manipula la emoción, se limita a dar estatus de ciencia a la psicología. Lejos de atender a las necesidades emocionales, el conductismo las ignora. Con la razón y la emoción por fuera del aprendizaje, con una academia que imita sin beneficio de aduana, se compromete con métodos que aplican altas dosis de estímulo-respuesta (Watson) y posteriormente con "El nuevo conductismo" (Skinner) estímulos positivos y estímulos negativos que permiten observar el comportamiento. Sin pluralidad humana, condicionamiento clásico (Watson) y condicionamiento operante (Skinner) serían suficientes para crear comportamientos, respuestas y hábitos "apropiados” y observables.

Sin posibilidad de ser observados, los sentimientos carecen de importancia. Sobre el conductismo, es una de las obras más importantes de B. F. Skinner, en ella, tal como sucedió con la Didáctica Magna de Comenio, se sentaron las bases filosóficas y psicológicas que terminaron por colonizar la educación de Occidente. A diferencia de Pavlov que pensó el condicionamiento, de Watson que partiendo del condicionamiento pavliano, desarrolló el conductismo, Skinner plantearía el "Neoconductismo" o conductismo operante.

Mientras que los primeros sustentaron el conductismo clásico en el que los estímulos perpetraban cambios internos (lo voluntario lo convertían en involuntario) como reflejos, el condicionamiento operante planteado por Skinner, se preocupaba por lograr comportamientos condicionados (voluntarios) pero a través de estímulos positivos y estímulos negativos, que conllevan a comportamientos susceptibles de ser observados, por lo tanto, reales. Leemos en Sobre el conductismo de Skinner:

[...] considérense solamente aquellos hechos que se pueden observar objetivamente en el comportamiento de una persona [...]. Si todos los vínculos son válidos, nada se pierde al descuidar los supuestos vínculos que no son físicos [...]. La distinción típica entre el comportamiento operante y el reflejo es la de que uno es voluntario y el otro es involuntario. Se tiene la sensación de que el comportamiento operante está bajo el control de la persona que se comporta, y tradicionalmente se le ha atribuido a un acto de voluntad. Por otra parte, el comportamiento reflejo no está bajo un control comparable, e incluso se le ha atribuido a poderes invasores (Skinner, 1974, pp. 2244).

Para una mejor comprensión, el siguiente esquema muestra de manera gráfica las convergencias y divergencias entre los tipos de conductismo: 


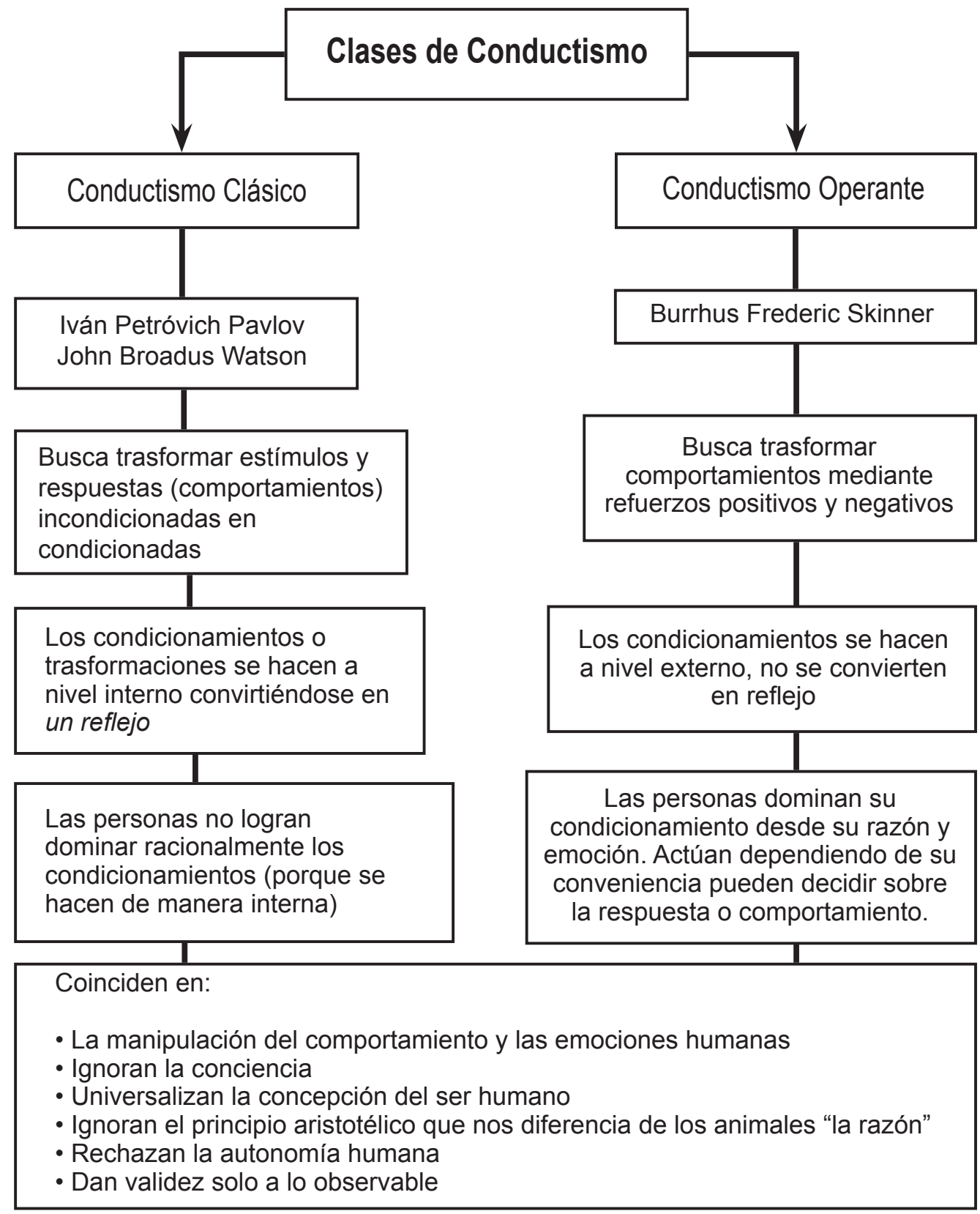


Mientras Platón y Aristóteles degradan la emoción al alma irracional, ambos conductismos, en cambio, hacen uso de ella con fines maniqueistas. Se hace evidente en Watson y Skinner, la manipulación de la emoción, en el primero (condicionamiento clásico), se torna involuntaria, y en el segundo (condicionamiento operante), "voluntaria", pero acotada por estímulos racionales y calculadores que dependerían de los intereses individuales. Sin embargo, Skinner en su intento por alejarse de la concepción de Pavlov y Watson, que ponían al mismo nivel animales y ser humano, terminó por legitimar lo que hoy se conoce como educación bancaria y repetitiva (Freire), en la que, a mayor repetición de un estímulo positivo, más se fortalece ese comportamiento, por lo tanto, se alarga la vida de la memoria. Continuamos con Sobre el conductismo:

El conductismo de Watson fue una "escuela" que se integró al cuerpo del conocimiento de la psicología contemporánea [...]. Entre los hechos comportamentales disponibles estaban los reflejos y los reflejos condicionados, y Watson los utilizó lo mejor que pudo [...]. Con el trabajo del fisiólogo ruso Pavlov, publicado por la misma época, se dio la misma impresión, que no se corrigió con la psicología de estímulo-respuesta que surgió durante las tres o cuatro décadas siguientes. Naturalmente, Watson enfatuó los resultados [...], y muchos de ellos se habían obtenido a partir de animales - la rata blanca de la psicología animal y los perros de Pavlov-. Parecería estar implícito que el comportamiento humano no tuviera características distintivas (Skinner, 1974, p. 22).

El concepto reduccionista de hombre, lo sería en detrimento del rol protagónico atribuido al lenguaje, máxime cuando lo asume desde la lingüística haciendo abstracción desde la pragmática, en la medida en que se sacrifican los usos a favor de las definiciones.

[...] También se vieron forzados a hacer interpretaciones precipitadas del comportamiento complejo; Watson, diciendo que el pensamiento era simplemente habla subvocal, y Pavlov, que el lenguaje era simplemente un «segundo sistema de señales». [...] El descubrimiento de principios de organización en la estructura del comportamiento - tales como los «universales» de las culturas o los lenguajes, los patrones arquetípicos de la literatura, o los tipos psicológicos- pueden hacer posible la predicción de casos de comportamiento que no han ocurrido previamente (pp. 14).

Concebido el tiempo como lineal, con una Historia con mayúscula y la edad como elemento que permite estudiar el comportamiento, el ser humano queda relegado a los modelos (Platón) y las taxonomías (Aristóteles) construidos para tal fin. Considerando el conductismo fundamentalmente un cambio de conducta, es decir, la forma concreta como un individuo actúa frente a una situación dada, lejos de ser el lenguaje un prerrequisito para desarrollar pensamiento, la prioridad estaría del lado de las conductas observables y sus cambios.

También se puede estudiar la estructura u organización del comportamiento en función del tiempo o de la edad, como en el desarrollo del comportamiento verbal del niño [...]. La historia enfatiza los cambios que ocurren en el tiempo, y si se pueden descubrir los patrones de desarrollo o de crecimiento, se puede probar que éstos son eficaces en la predicción de acontecimientos futuros (pp. 21). 


\subsection{Concepciones educativas desde el condicionamiento operante}

El aprendizaje ocurre con la repetición de un refuerzo positivo. En la medida que el refuerzo positivo fortalece el comportamiento, el aprendizaje se hace más visible. La eliminación de una conducta indeseable funcionaria de la misma forma, la repetición de un estímulo negativo (el castigo por ejemplo) no solo la debilita, sino que, además, posteriormente puede ser objeto de refuerzos positivos que buscan implementar una conducta deseable.

El docente, es el experto, es decir, el centro del proceso enseñanza-aprendizaje, monopoliza la palabra y la acción, decide cuándo hay aprendizaje, centraliza el poder, la autoridad y las decisiones, considera el estudiante como un receptor pasivo. El docente decide además, qué y cómo puede haber aprendizaje. Planear ambientes que favorezcan los refuerzos positivos (favorecer la repetición de un comportamiento) o refuerzos negativos (debilitar y eliminar un comportamiento poco favorable), es parte de sus compromisos.

El maestro debe cultivar la mente como el agricultor cultiva sus campos, y el intelecto se debe ejercitar como la parra se ejercita en la viña [...]. Sin embargo, el objetivo de la educación se puede formular en términos comportamentales: el maestro prepara las contingencias bajo las cuales el estudiante adquiere el comportamiento que le será útil bajo otras contingencias más tarde. Las contingencias instruccionales se deben preparar; no hay otra forma de hacerlo (Skinner, 1974, pp. 107).

Despojados de sus vivencias, intereses y cultura, los estudiantes entrarían a clase como "tabulas rasas". En general, el conductismo introdujo la enseñanza automatizada, los libros de trabajo (cuadernos "workbooks"), las conductas positivas que premiadas tienden a repetirse y las negativas que castigadas tienden a eliminarse. Posiblemente influenciado por la tradición aristotélica que impacta a la vida intelectual de occidente, la metáfora es vista por Skinner como ornamento. Leemos en Sobre el conductismo:

Los términos referentes a los estados emocionales o motivacionales muestran a menudo cierta relación con las circunstancias externas que los generan. Por ejemplo, nos sentimos tristes en el sentido original de entristecidos, o excitados en el sentido de perturbados, pero estas expresiones apenas pueden ser algo más que metáforas (pp. 32).

La psicología conductual, representada, entre otros, por Watson (1913) con el conductismo clásico, y por Skinner (1977) con el operante, reduce la emoción a una respuesta del organismo a los condicionamientos externos, es decir, a una conducta observable. Ignorada en el primer caso y manipulada en el segundo, se deja de lado la dinámica razón-emoción.

La expresión de la vida emocional y motivaciones de la mente se ha descrito como uno de los grandes logros en la historia del pensamiento humano, pero es posible que haya sido uno de los grandes desastres. En su búsqueda de explicación interna, apoyada en el falso sentido de causa asociada a los sentimentalismos se ha oscurecido los antecedentes ambientales que habrían conducido a un análisis más efectivo (pp. 153). 
A pesar de las severas críticas hechas por Skinner al estudio de las emociones desde otro enfoque diferente al conductismo, es posible ver con más claridad que nunca, la ignorancia con respecto al poder de la emoción.

La exploración de la vida emocional y motivacional de la mente se ha descrito como uno de los grandes logros en la historia del pensamiento humano, pero es posible que haya sido uno de los grandes desastres. Decir que «matan las mentes, no los fusiles», simplemente equivale a decir que no controlaremos a los asesinos evitando que haya armas disponibles [...]. La psique, como la mente, es una metáfora que se torna plausible por la aparente importancia de lo que la persona siente $\mathrm{u}$ observa introspectivamente, pero que está destinada a permanecer siempre en las profundidades. En cambio, el ambiente es accesible comúnmente (pp. 153).

En síntesis, los aspectos cognitivos de la emoción y las respuestas cognitivas emocionales como respuestas encubiertas (no observables que se pueden condicionar de la misma forma que las respuestas abiertas observables) comienzan a ser estudiados por los neo conductistas de los años sesenta. De la misma forma que lo hizo la teoría de las ideas de Platón, las taxonomías de Aristóteles y el método de Comenio, el conductismo constituye un abordaje unilateral del mundo.

\subsection{Implicaciones educativas}

Si el conductismo es mayéutica vergonzante, se hace imperioso adelantar un giro que ponga en tela de juicio teorías que han hecho carrera en la academia y que evitan el pensar reduciendo al estudiante a la mera repetición o eliminación de conductas inaceptables.

La coexistencia de varias culturas en un mismo espacio no solo físico, sino además, mental, exige repensar los fines educativos y la adopción de estrategias integradoras ante la diversidad étnica y lingüística. A la vez que la multiculturalidad se potencia, los avances tecnológicos ofrecen otras formas de interactuar ampliando el panorama de posibilidades de relaciones sociales y educativas. Comprometerse con un método, una facultad, una verdad como lo hacen Platón, Aristóteles, Comenio y Skinner son extravíos intelectuales, en un tiempo en el que la antropología ha sido sacudida por teorías como la del cerebro triuno (MacLean), la comprensión de la multiculturalidad todavía es escasa, cuando los viejos conceptos devienen obsoletos con rapidez, y nuevos términos como la globalización y la multiculturalidad han de ser incorporados con el fin de interpretar la complejidad del mundo a riesgo de sucumbir en el anacronismo en caso contrario.

Si los últimos avances científicos demuestran que la emoción juega un papel estelar, se hace necesario reivindicarla en un momento de la historia en el que se ha descubierto el vínculo de la emoción con la memoria y se ha puesto en entredicho, no solo los principios conductistas, sino, además, la relación con la felicidad producto del consumo. 


\section{La crisis de las fórmulas}

En un mundo verdaderamente interino en el que todo cambia cada vez más rápido, una educación repetitiva y reproductora, cuando no mecanicista, se hace cada vez más inapropiada. Por fortuna, los nuevos desarrollos intelectuales y culturales proporcionan una serie de estrategias particularmente útiles a la hora de repensar la educación. Nos interesan tres casos.

- Habiendo hecho crisis el universalismo y carrera el multiculturalismo, el hombre no se aborda desde una antropología esencialista, sino, desde una sociología contextualista.

- Con el giro lingüístico, la razón se revela una careta del lenguaje. En su condición de fenómeno interactivo, no existe el lenguaje en sí, sino que uno siempre habla desde sus propios prejuicios con un interlocutor particular y en un contexto específico. En contravía con la hipotética razón pura, el lenguaje no es neutral. Es cuando se impone la pragmática lingüística y la relatividad lingüística.

- Cuando Nietzsche plantea que el hombre es solo cuerpo se opone por igual a la filosofía clásica griega y al monoteísmo que asumen, en cambio, la distinción cuerpoalma en la que se fundaba el reinado indiscutido de la razón sobre las demás facultades. La emoción, la pasión, los sentimientos y el instinto dejan de ser vistos como fuerzas negativas, al tiempo que se les reconoce su protagonismo en la construcción del mundo para el hombre.

Si el mundo es plural, si el lenguaje no es acolito del pensamiento, si el cerebro además de razón, alberga emoción, si la emoción es necesaria para la cohesión social, creemos oportuno registrar aportes teóricos en esa dirección, que aspiren a remover desde sus raíces metafísicas las prácticas pedagógicas desuetas y habiliten otras opciones para la educación del siglo XXI.

\subsection{Sociología contemporánea}

Las revoluciones políticas, la revolución industrial, el advenimiento del socialismo y la crisis de las religiones, inclusive, bastarían para comprender la ráfaga de cambios sociales gestados durante los últimos siglos. La desacralización de la razón podría incluirse en la lista. En Postmodern Social Theory de George Ritzer (1997), el autor afirma:

[...] Hay muchas formas de caracterizar la diferencia entre los mundos moderno y postmoderno, pero, como ejemplo, una de las mejores es la diferencia en puntos de vista sobre si es posible encontrar soluciones racionales [...] a los problemas de la sociedad (http://www.tebeosfera.com). 
La época postmoderna, pierde la fe en la razón. Al igual que Ritzer, grandes pensadores como Karl Marx, Emite Durkheim y Max Weber permiten comprender los cambios sociales del siglo XIX y principios del XX. Los pensadores en cuestión hacen evidente, cada uno a su manera, aspectos irracionales del mundo. Que la idea de razón ilustrada que encaminó a los hombres a elaborar un proyecto de sociedad más libre e igualitaria sostenida en criterios meramente racionales haya fracasado, obliga a repensar algunos de los supuestos de la sociedad contemporánea, como en efecto hacen los sociólogos Sigmund Bauman (2002) y Guilles Lipovetsky (2007).

Los sociólogos más destacados de las últimas décadas han develado la dinámica de una sociedad que se dice racional, pero detrás de la cual abundan las punciones y los egoísmos en dirección contraria. El marketing publicitario sería un ejemplo prototípico de la manipulación de la emoción con fines consumistas.

Regatear, comparar y seleccionar nos hace sentir libres, pero somos marionetas de la publicidad, la misma que ha ido ganando espacio en nuestras vidas hasta comprometernos con el hiperconsumo y la felicidad a corto plazo. La emoción, no mediatizada por la razón o por lo menos no depende de ella, induce el hiperconsumo como un fin en sí mismo. El placer obtenido en la compra, opera como un refuerzo positivo que induce la nueva compra dentro de un esquema conductista de clara estirpe skinneriana.

Lejos de hacer posible la cohesión social, el consumismo fragmenta en estratos y marcas. De espalda a las oportunidades y los compromisos, la academia, en el otro extremo del espectro, continúa brindando el conocimiento desconectado de la emoción que rápidamente se degrada en olvido.

En proceso de disolución del ente social, el imperio del individualismo apoderado de todas las facetas que envuelven al siglo XXI, nos hace cada vez más intolerantes y desdichados. Gilles Lipovetsky (2007) brinda estrategias desde la sociología y la filosofía contemporánea para comprender el círculo vicioso en que hemos caído. Sus postulados, han ejercido notable influencia en los ámbitos académicos y culturales de todo el orden.

Un capitalismo que no se concibe por fuera del crecimiento arrastra a la sociedad en una vorágine de cambios cuya velocidad supera la capacidad de adaptación al medio, de una especie como la nuestra que durante la prehistoria se construyó de cara al peligro antes que del cambio. Con reconocida lucidez, Bauman (2002) acuña la metáfora del tiempo líquido para representar la situación en la que nos encontramos con un mundo que cambia más rápido que lo que estamos en condiciones de soportar. Abundan las consecuencias derivadas del desajuste en cuestión.

Dos rasgos, en síntesis, caracterizan la sociedad contemporánea: el consumismo y la interinidad. En el primer caso, nos ocuparemos de las fases del capitalismo a partir de Lipovetsky (2007), en el segundo caso, del tiempo líquido en relación a Bauman (2002). 


\subsubsection{Gilles Lipovetsky}

Con la conversión del capitalismo en consumismo, y este último el motor principal de la condición humana, la sociología ha adquirido un rol de primer orden a la hora de explicar lo ocurrido a partir de la finalización de la Segunda Guerra Mundial. No es de extrañarnos así que un sociólogo de profesión como Habermas se haya convertido en uno de los filósofos más destacados de las últimas décadas. Erigir la sociología en una especie de filosofía del siglo XXI, no deja de presentar múltiples riesgos. En tiempos del cambio climático, el fin de los recursos naturales y el capitalismo desenfrenado, el mundo no solo está por explicar, sino, particularmente por cambiar. Una mirada socio céntrica correría el peligro de hacernos cómplices del statu quo.

En algunos de sus más importantes escritos como: "Metamorfosis de la cultura liberal", "El crepúsculo del deber", "Los tiempos Hipermodernos", "La sociedad de la Decepción" y "La era del vacío", este filósofo francés muestra la filiación de una sociedad movida por el impulso de lo "neo", es decir, de la novedad, hasta convertirnos en una sociedad neofílica. Sin dejar de lado las ideas subyacentes en cada uno de los escritos ya mencionados, nos centraremos especialmente en La felicidad paradójica, en la que este sociólogo francés se ocupa de algunos síntomas del mundo contemporáneo como el consumo emocional y la felicidad paradójica. Leemos en el mencionado escrito:

[...] la nueva era del capitalismo se construye estructuralmente alrededor de dos agentes fundamentales: el accionista por un lado y el consumidor por el otro. [...] En relación con el segundo, el imperativo es comercializar todas las experiencias en todo lugar, en todo momento y para todas las edades, diversificar la oferta adaptándola a las expectativas de los compradores, reducir los ciclos de vida de los productos mediante la aceleración de las innovaciones, segmentar los mercados, fomentar el crédito para el consumo [...]. El hiperconsumidor puede acceder a placeres cada vez más numerosos y frecuentes, gustar los innumerables goces de las libertades, las evasiones y los cambios. Si bien estos consumos no son sinónimos de felicidad (Lipovetsky, 2007, pp. 9 - 13).

Con pequeñas parcelas de felicidad instantánea, desde el momento en que se logra adquirir la novedad impuesta por la sociedad de consumo, se cae en el estado de ansiedad por conseguir de cualquier modo y a cualquier precio la siguiente dosis. No es otra la adicción a las dosis de felicidad instantánea, no obstante, desechable. Que la apuesta por el consumo ha sido exacerbada por el capitalismo es un hecho por todos conocido; que es posible distinguir algunas etapas es uno de los temas abordados por Lipovetsky en La felicidad paradójica. El sociólogo francés distingue tres fases:

Fase 1: Desde 1880 hasta la Segunda Guerra Mundial, estaría enmarcada la primera fase, caracterizada por la aparición de modernas infraestructuras de transporte y comunicaciones facilitando la producción en serie, gracias a los nuevos métodos y procedimientos de 
fabricación industrial.

La fase I, inventó [...] el comercio a gran escala [...] la mercadotecnia de masas, el consumidor moderno [...] el consumo-seducción y el consumo-distracción del que somos fieles herederos [...] la fase 1, trasformó el cliente tradicional en consumidor moderno (pp. 25 - 27).

Con la revolución industrial se hace posible la producción en serie, y en lo sucesivo tienen acceso al mercado una parte importante de la población que hasta entonces permanecía al margen. Un porcentaje creciente de la población puede satisfacer sus necesidades en la medida en que el relevo del artesano por la fábrica abarata los costos, y en ese orden de ideas la recompensa y el placer se encuentra en el "uso".

El capitalismo de consumo no nació automáticamente con las técnicas industriales capaces de producir mercancías estandarizadas en grandes series. Es también una construcción cultural y social que requirió por igual la «educación» de los consumidores y el espíritu visionario de los empresarios creativos, la «mano visible de los directivos». En la base de la economía de consumo se encuentra una nueva filosofía comercial, una estrategia que rompe con las actitudes del pasado: vender la máxima cantidad de productos con un pequeño margen de beneficios antes que una cantidad pequeña con un margen amplio. El beneficio no vendrá ya por la subida del precio de venta, sino por su reducción. La economía de consumo es inseparable de esta invención mercadotécnica: la búsqueda del beneficio por el volumen y la práctica del bajo precio. Poner los productos al alcance de las masas: la era moderna del consumo comporta un proyecto de democratización del acceso a los bienes comerciales (pp. 24).

Mientras la educación ignora el poder de la emoción que puede abrir o cerrar futuro, el capitalismo la utiliza hasta sus últimas consecuencias. Contrarrestar el consumismo solo con argumentos no es tarea fácil; sin el concurso de la emoción hace falta la motivación sin la cual la educación difícilmente hace la diferencia.

Fase 2: Con posterioridad a la Segunda Guerra Mundial, en el período comprendido entre 1950 y 1970, se ubica la segunda etapa que serviría de escenario al consumidor ya inventado. La generalización de los productos de consumo en todos los grupos sociales, el crecimiento económico y la elevación del nivel de productividad del trabajo permitirían el fácil acceso no solo a los elementos básicos (alimentación, educación, vestido), sino, además, a los de segundo y tercer orden (moda, el ocio).

Con la revolución industrial y la súper oferta de productos y promociones, en esta etapa la gente no solo compra para satisfacer sus necesidades, sino, también, para diferenciarse de los demás y formar grupos que comparten preocupaciones inmediatas. La publicidad presentó los más altos índices de "construcción" de necesidades y realidades sociales. Es cuando la ostentación de los bienes obtenidos en el mercado adquiere un papel estelar, al servicio de una diferenciación (o discriminación) social. El principio de la seducción y de lo efímero, inicia 
su travesía por la "sociedad del deseo", acelerando la expansión de la sociedad, al tiempo que convierte la satisfacción del deseo en un fin en sí mismo.

[...] En el curso de esta fase se construye, hablando propiamente la "sociedad del consumo de masas" como proyecto de sociedad y fin supremo de las sociedades occidentales. [...] Toda a una sociedad de moviliza alrededor del proyecto de conseguir una cotidianidad cómoda y fácil, que es sinónimo de felicidad. [...] Es un tipo de sociedad en el que la seducción reemplaza la coerción, el hedonismo al deber, el gasto al ahorro, el humor a la solemnidad, la liberación a la represión, el presente las promesas del futuro. [...] Se estimula el crédito para adquirir las maravillas del país de Jauja, para realizar deseos inmediato (pp. 30 - 31).

El consumo en función del estatus, de la exhibición impúdica de todo tipo de bienes, refuerza el narcisismo; en su condición de consumo que implica una satisfacción desechable, convive con la lógica del vacío.

Fase 3: Después de la competencia consumista se inicia la tercera fase desde los años 80 hasta nuestros días. Esta etapa se caracteriza por el desplazamiento del placer que en la fase anterior dependía de la emulación (reconocimiento social, simpatía, fama) al placer propio (afecto, felicidad, estéticas, sensación de plenitud).

De la misma forma que lo hizo la sociedad de la vigilancia formulada por Foucault, la teoría de la felicidad paradójica planteada por Lipovetsky, conserva su vigencia en el siglo XXI. Sin una sociedad autónoma, el capitalismo controlaría los estímulos individuales. Paradójicamente, Lipovetsky decide platear a finales de los años 70 y principios de los 80 , el inicio de un proceso de liberación del sujeto a través de la mencionada sociedad de consumo, convirtiéndose en un consumo de emociones. Por el camino del consumismo emocional, se refuerza el materialismo y se fomenta el individualismo propio del capitalismo. Continuamos con $\mathrm{La}$ felicidad paradójica:

[...] La nueva era del capitalismo se construye estructuralmente alrededor de dos agentes fundamentales: el accionista por un lado y el consumidor por el otro [...], hemos pasado de una economía orientada hacia la oferta a una economía orientada hacia la demanda. Política de marca, "creación de valor para el cliente", sistemas de fidelización, presión de la segmentación y la comunicación: hay en marcha una revolución copernicana que reemplaza la empresa "orientada al producto" por la empresa orientada al mercado y al consumidor (pp. 8).

La segunda mitad del siglo XX, es testigo del desmesurado crecimiento de las ciudades, la violencia, la contaminación, el desempleo, la drogadicción, el analfabetismo funcional, inclusive. Habitamos un mundo caótico en el que lo contingente nos desborda, todo se fragmenta, las acciones se multiplican y el tiempo parece recortarse, en definitiva un mundo acelerado, cambiante y transitorio. 
Con la aparición de un nuevo arquetipo social, en la fase 3, el hipermaterialismo de la gente es reforzado por el hiperconsumo. Se invierte y rinde culto a la salud y se consumen de acuerdo con Lipovetsky, "píldoras de felicidad", sobreponiendo "el valor que distrae sobre el valor que honra”. Al comprar por placer sin vincular la razón, la acción en cuestión pasa a ser un problema de consumo emocional, en el que las necesidades emocionales no terminan de ser satisfechas, cediendo su paso a la decepción, la frustración, la angustia, cuando no a la violencia.

Esta lógica igualitaria, y portadora de exigencias sin fin se intensifica en nuestros días por mediación de esas metas que son la autonomía subjetiva, la salud, el bienestar la distracción, la comunicación y que, se caracterizan por ser axiomáticas sin territorialidad fija, que se trazan cada vez más lejos sus fronteras y no conocen la saturación [...]. En la fase III, el consumo [...] es una forma de consuelo, funciona igualmente como agente de experiencias emocionales que tienen un fin en sí mismas (pp. 53 - 55).

Reivindicada la emoción, desplegados los cambios sociales que van de la producción masiva al consumismo desenfrenado, presenciamos la metamorfosis del consumo hasta convertirse en un fin en sí mismo.

En el marco del intelectualismo y la (lo que no deja de ser paradójico) fe en la razón cuando el currículo nos ahorra pensar, lo que se traduce en una especie de jubilación anticipada, la educación actual (educación 1) no tendría más remedio que reconocer su pecado capital al expulsar la emoción. Es necesario abrir paso a otras formas de acceder al conocimiento (educación 2) de cara a las trasformaciones sociales, en las cuales, la conexión emoción-razón resulta trascendental.

Bauman (2002), coincidiendo con Lipovetsky, cuando categoriza los espacios públicos como espacios para el consumo y no para la interacción social, demuestra que la sociedad se hace un apéndice del capitalismo:

La segunda categoría del espacio público pero no civil está destinada a prestar servicios a los consumidores o, más bien a convertir al residente de la ciudad en consumidor [...]. Esos espacios públicos instan a la acción no a la interacción. El hecho de compartir el espacio físico con otros actores abocados a una actividad semejante añade importancia a la acción, le da el sello de la "aprobación numérica" y de ese modo corrobora su sentido, lo justifica [...], cualquier interacción entre los actores los distraería de las acciones a las que están abocados individualmente [...]. No agregaría nada al placer de ir de compras, sino que solo serviría para distraer la mente y el cuerpo de la tarea prevista (Bauman, 2000, pp. 105).

Consumir de más y pensar de menos, así como el imperio de la distracción como secuelas del consumismo, han sido objeto de crítica en las últimas décadas por una serie de movimientos sociales e intelectuales que van desde el Mayo francés del 68, un movimiento iniciado por el estamento universitario al que posteriormente se unieron los sindicatos, los grupos de obreros 
industriales y el partido comunista inclusive; durante dos meses (mayo y junio) sentar su desacuerdo y declaró una feroz guerra contra el sistema, el consumismo y los mass-media por él impuestos, hasta el movimiento de los indignados (15-M), en el que reclaman la presencia de una democracia no mediada por los partidos tradicionales bajo el lema "Democracia real ¡YA! No somos mercancía en manos de políticos y banqueros”.

Superada la etapa de la emulación social, el consumo y el capitalismo dirigieron sus esfuerzos hacia la construcción de lo individual. Al tiempo que Lipovetsky emprende la crítica de la sociedad del momento en relación con el papel del sujeto en una sociedad del consumo, no deja de preocuparse por la liberación del individuo de los mandatos de la publicidad.

La sociedad del consumo, amparada en el liberalismo económico ha puesto las condiciones necesarias para la exacerbación del individualismo. Es posible rastrear en los postulados de Lipovetsky, una sociedad sumergida en un mundo hiperconsumista y neofílico, que entiende la libertad en el estrecho marco del consumismo no para que el individuo emule con sus semejantes, como en la fase 2 , sino para satisfacer sus adicciones, en la fase 3.

En la actualidad, la publicidad que vende necesidades a cuotas y satisfacción desechable, es más protagónica que nunca. Con los deseos directamente relacionados con las frustraciones y sin una educación que entrene para la felicidad como eudaimonía, quedamos presa fácil del consumismo desenfrenado. Leemos en La felicidad paradójica:

[...] En los procesos incoados contra el cosmos consumista, la publicidad ocupa, como se sabe, un lugar primordial. Por machacar a los consumidores, por crear necesidades superfluas, por lanzar incesantemente nuevos deseos de comprar, por identificar la felicidad con los bienes comerciales, se ha acusado a la publicidad no solo de manipular, estandarizar e idiotizar a las personas, sino también de ser una trampa diabólica que hincha hasta el infinito la insatisfacción individual (Lipovetsky, 2007, pp. 163).

La sociedad de consumo a través de sus estrategias de mercado como la publicidad nos arrebata incluso decisiones relacionadas con la vida cotidiana y de supervivencia: qué comer, cómo y dónde dormir, cómo concebir. En la actualidad, estas decisiones no dependen de nuestras necesidades o juicios, sino, de la oferta publicitaria del momento. Opuesta a la academia, la publicidad ha supeditado la felicidad al consumismo. Su capacidad para frustrar sistemáticamente se basa en una nueva configuración del poder de la oferta económica y de la manipulación neuronal como lo sostiene el sicólogo francés Repaille.

Neuroeconomía y neuromarketing son temas comunes en una sociedad en la que la emoción cobra más relevancia que nunca. Mientras la neuroeconomía (Loewenstein) pone en tela de juicio antiguos postulados de la economía tradicional sobre la capacidad del hombre para razonar y planear sus gastos y compras, el neuromarketing (Repaille) reconoce y navega entre las emociones del consumidor desarrollando una especie de diagnóstico que le permite identificar deseos y necesidades para producir mercancía en consecuencia. Estas pericias 
publicitarias, demandan que la academia reflexione sobre sus prácticas pedagógicas de antaño y promueva otras que le permitan competir con las mencionadas estrategias. Con doctorado en emociones, la mercadotecnia estudia los efectos que la publicidad tiene en el cerebro humano, logrando predecir la conducta del consumidor.

Habiéndose identificado la existencia del neocortex y del cerebro primitivo de tiempo atrás, el progresivo descubrimiento del sistema límbico permitió a Papez y MacLean, elaborar la teoría de los tres cerebros: el cerebro primitivo o reptil (subconsciente), el cerebro límbico (sentimientos y emociones) y el nuevo cerebro o córtex (razón). Cada uno posee funciones específicas. El psicólogo francés Clotaire Rapaille, reconociendo la presencia de los tres cerebros, descubrió que es en el cerebro reptil, sede del subconsciente, donde se controlan las decisiones finales. En adelante, profundizó en la comprensión de los comportamientos neuronales que rigen la intención o la decisión humana. De acuerdo con Repaille, los llamados "botones del corazón reptiliano", apelan al impulso más primitivo del inconsciente y termina en acciones concretas, premeditadas, y alineadas con una estrategia de mercado, dejándonos vulnerables frente a la sociedad de consumo. Repaille parte de la base de que una persona no sabe lo que realmente quiere, y por lo tanto, no podrá comunicarlo, pero sí actuará de acuerdo a esos estímulos.

Al descubrir que la decisión de comprar un producto no depende de la razón, sino del tránsito del mensaje publicitario a través de la conciencia (corteza cerebral y cerebro racional) y el sistema límbico hasta llegar al inconsciente (cerebro reptiliano), la publicidad se convierte en una máquina que inventa necesidades humanas secundarias disfrazadas de primarias. Manipulados los cerebros límbico y reptil, ignorado el racional y sin una academia que contrarreste la manipulación publicitaria, los estudiantes quedan presa fácil de la mercadotecnia. Al desconectarse la emoción de la razón en la academia, la emoción, por acción de la publicidad se conecta con el instinto. Esta manipulación de la emoción, en la que se vende felicidad no sostenible y con fines consumistas, se puede evidenciar, entre otros, en pancartas y vallas.

Figura 1. Presencia de la conexión emoción-razón en la publicidad.

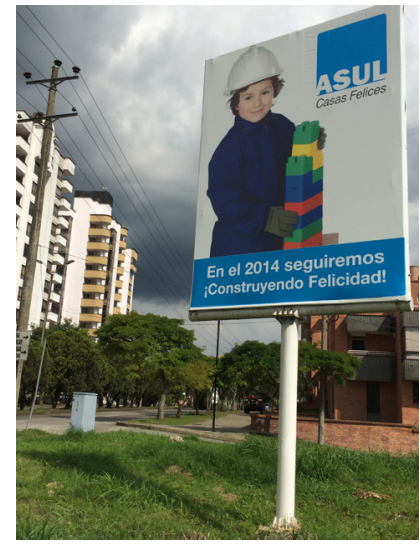

Fuente: La autora 
La publicidad, consciente del poder emocional de las figuras literarias como la metáfora, la expresión "casas felices", atribuye características humanas a paredes de concreto. Con posibilidades de ser construida y diseñada de acuerdo a las necesidades, la felicidad no dependería de nuestro interior, sino, de aquellos que se dedican a la construcción.

Que el maniqueísmo emocional, gestado por la mercadotécnica, sea utilizado con fines políticos, es una evidencia consuetudinaria que bordea lo ridículo. Durante las últimas décadas la credibilidad en la política ha venido en descenso, conscientes de ello y del valor moral y emocional que representa la familia, las vallas publicitarias de las campañas políticas, copian de la publicidad cuando utilizan la emoción no vinculada a la razón sino, al instinto.

Figura 2. Presencia de la conexión emoción-razón en la política

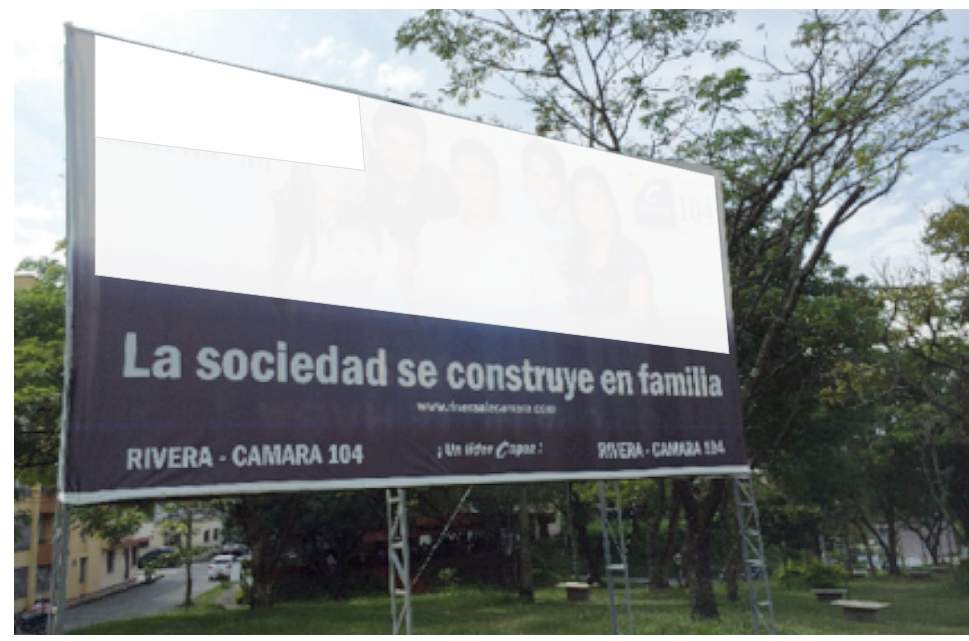

Fuente: la autora

Activado el "botón clave del reptil" (Repaille), nuestras preferencias por un candidato político, estaría determinado no solo por las "improntas" subconscientes del cerebro reptil, sino, además, por las emociones y sentimientos que representa nuestra familia. Al respecto él sostiene:

Es absolutamente crucial para cualquier persona que trabaje en comunicación -ya sea periodista, TV, medios o marketing - si quiere atraer la atención de la gente, debe entender lo que yo denomino el botón clave del reptil (the reptilian hot button). Si no tiene ese botón, entonces tendrá que vérselas con el córtex y trabajar con atributos como el precio y cosas por el estilo (Entrevista para Frontline (PBS), el 15 de diciembre de 2003).

Si en la disyuntiva Reptil vs Córtex, "el reptil siempre gana", de acuerdo con Repaille, no importa la realidad, no importa la lógica, importan los estímulos que emocionan, cuando no es que se conectan con el instinto. Mercadotecnia y politecnia se valen del poder de la 
emoción, cuando no del instinto; la educación, en cambio, a menudo no es otra cosa que la apuesta de los agelastos por la ataraxia.

Lejos de otorgar centralidad a la emoción, la academia es la isla de lo racional, quedando avasallada por la publicidad que reconoce en todas sus formas el poder de lo emocional.

Gracias al Neuromarketing y a la Resonancia Magnética Funcional, se pueden establecer de acuerdo con Palazzesi, tres características esenciales que nos hace presa fácil del consumismo: la manipulación del inconsciente, los hábitos y el sistema emocional.

El principal instrumento que utiliza son las Imágenes por. Gracias a estas imágenes, se puede establecer algunos hechos: Neuromarketing y la Toma de Decisiones En primer lugar: se descubrió que la decisión de comprar o no un producto determinado no es racional, sino que deriva de fuerzas inconscientes, por ejemplo, las compras impulsivas [...]. Segundo término se determinó que: la mayoría de las veces, el proceso de selección de compra de un bien o un servicio es algo relativamente automático. Esta acción se deriva de los hábitos adquiridos a lo largo de la vida del consumidor y otras fuerzas inconscientes, entre las cuales tienen mucho peso la propia historia del consumidor, la personalidad, las características neurofisiológicas y el contexto físico y social que lo rodea, etc. [...]. Por último, el sistema emocional: una de las zonas más antiguas del cerebro, juega un papel muy importante en los procesos mentales de los humanos, y por lo tanto determina en gran parte el rumbo de las decisiones de compra. Y como todos sabemos, desde el punto de vista estrictamente racional, dejarse influir por las emociones a la hora de comprar no es nada bueno para las finanzas (Ariel Palazzesi).

Que la publicidad utilice el poder de la emoción sin pudor y sin recato, copa el interés de los ciudadanos transformados en consumidores ante los cuales la academia deja de ser una opción prioritaria pues no compite en sus mismos términos. No se trataría de satanizar la publicidad, sino, de integrarla al acto educativo, de acuerdo con Pozo (1999) en Aprendices y maestros. Si el aprendizaje que genera la publicidad puede ubicarse dentro del esquema conceptual con contenidos implícitos en oposición a la educación formal, resulta urgente que la academia renuncie a lo explícito, bancario y repetitivo.

Si el maestro intenta trasmitir nuevos conceptos a los educandos, así como el publicista intenta comunicar las marcas a los consumidores, entonces, el maestro no solo debe convertirse en un ingenioso "publicista" del conocimiento que quiere compartir, sino, además, en un gestor y reconciliador de la conexión emoción-razón de suerte que devuelva la humanización a la educación, la misma que brilla por su ausencia en la actualidad. Aunque en el primer caso se busca que haya aprendizaje y en el segundo que haya compra, inevitablemente en ambos se produce un proceso complementario no intencional: el publicista también enseña y el maestro también vende (Cfr. Gill, 1977). 
De acuerdo con Pozo, el aprendizaje sin enseñanza que proporciona la publicidad o la enseñanza sin aprendizaje que proporciona la academia, sería la dicotomía en la que quedan atrapados los estudiantes al enfrentarse a una sociedad individualizada y una educación sin emoción.

Entrenados para el hiperconsumo, con la llegada del imperio individualista, con las nuevas temporalidades humanas, ignorado el poder de la conexión emoción-razón, la educación queda sin futuro, es decir, sin posibilidades. Lejos de ser exclusivo de la clase alta, el ideal de bienestar y el nuevo capitalismo se presentan volátiles como lo define Lipovetsky o fluidos como lo define Bauman (2002).

Si el hombre intercambia ininterrumpidamente elementos culturales y sociales con el medio, si el mundo y la sociedad cambian, la educación debería entrenar para el cambio y no para la permanencia, por lo tanto, la educación debe renovarse y tener en cuenta el contexto, lo que nos llevaría a hablar de una segunda educación (educación 2).

\subsubsection{Sigmund Bauman}

Explorados los atributos de la sociedad capitalista, naturalizado el individualismo, de acuerdo con Lipovetsky, la sociedad moderna se caracteriza, además, por las condiciones precarias, transitorias y volátiles, de acuerdo con Bauman (2002). Con una modernidad cambiante, las certezas se hacen cada vez más escasas. Es cuando sobreviene la incertidumbre. El concepto de Modernidad líquida acuñado por Bauman (2002), hace referencia a la mayor velocidad de los cambios históricos respecto a la capacidad del individuo para adaptarse a ellos.

Entre los autores que se niegan a reducir el tiempo al del reloj, está Bauman. El tiempo no es el mismo a través de la historia aunque el reloj no cambie sus parámetros de funcionamiento. La metáfora del tiempo líquido ha impactado el mundo contemporáneo con una fuerza demoledora, pues nadie puede decir que no lo esté viviendo a diario. Restaría no obstante, preguntarnos si el tiempo líquido es una fatalidad, una oportunidad, un desvío o una opción y tomar la medida a que hubiere lugar, según las respuestas que demos a tales preguntas. Como lo decíamos en el caso de Lipovetsky, la sociología se queda corta.

Con la aceleración del tiempo, hay un punto en que el hombre se convierte en un ser inadaptado. Para utilizar una metáfora de Bauman, el hombre no gobierna su tiempo sino que se limita a surfear sobre él. Modernidad líquida y tiempo líquido, "fluidez" o "liquidez" son metáforas que usa para advertir de un lado, el sólido anacronismo de la educación, y del otro lado, la nueva historia de la modernidad.

Las cosas están cambiando a un ritmo tan rápido que no da tiempo de organizarlas cuando ya nos las han cambiado nuevamente. Reconoce entre los cambios sociales, el consumo emocional que nos hace comprar no para satisfacer necesidades sino como un acto que emociona y da sentido, encerrándonos en un nefasto e infinito círculo que nos vuelve eminentemente consumistas. Sin una academia que motive, quedamos sin más opciones de valor que el precio. 
Si la emoción al servicio del capitalismo cierra, en su condición de estímulo desechable; la emoción al servicio de la educación, en cambio, abre, en la medida que se transmuta en motivación, proporcionando no solo sentido individual, sino, además, cohesión social. No se trata de reemplazar la razón por la emoción, porque mientras la emoción da fuerza, la razón da claridad y precisión. Claridad sin fuerza es apatía, fuerza sin claridad es barbarie, su conexión sería la clave.

Todas las imágenes de una sociedad feliz pintadas por distintas brochas y en variados colores durante los últimos dos siglos demostraron se quimeras inalcanzables, o en los casos en que su advenimiento se produjo, insoportables [...]. Hoy viajamos sin una idea de destino que nos guie. Ni buscamos una sociedad mejor ni sabemos con certeza qué elemento de la sociedad en la que vivimos nos hace indiferentes y nos impulsa a escapar (Bauman, 2002, pp. 143).

El déficit motivacional de las éticas cognoscitivas del que se quejan los filósofos, estaría haciéndonos menos felices y más competitivos. La falta de altruismo y sensibilidad hacia los demás aleja cada vez más la posibilidad del bienestar y la tranquilidad social. Bauman (2002) comparte con Martha Nussbaum (1997) la preocupación por despertar en las personas la humanidad que cada una posee. De acuerdo con los dos pensadores, este sería el anhelo para la educación actual, porque solo de esta forma estaríamos preparados para afrontar las vicisitudes de un mundo que se renueva a diario.

Divorciado del grandioso diseño de la misión común y universal de la humanidad y del no menos grandioso diseño de la vocación de vida [...] el trabajo ha perdido la centralidad que le fue asignada en la galaxia de los valores dominantes de la era de la modernidad sólida y el capitalismo pesado. El "trabajo" ya no puede ofrecer un huso seguro en el cual enrollar y fijar definiciones del yo, identidades y proyectos de vida. Tampoco puede ser pensado como fundamento ético de la sociedad, ni como eje ético de la vida individual (pp. 149).

Haber emulado la promesa de felicidad del más allá (hazaña gestada por el consumismo), al reducir el paraíso al mercado, el capitalismo consumista no ha terminado por conjurar fenómenos como la depresión humana, entre otras cosas, porque la satisfacción que proporciona el mercado no necesariamente trasciende la compra. La academia, forastera a las mencionadas vicisitudes, continúa comprometiendo los estudiantes con una historia, una verdad y un método, se rehúsa a lo connotativo, concibe el lenguaje como mera razón, lo despoja de su poder emotivo en detrimento de los efectos perlocucionarios (Austin).

La academia prefiere ser el reducto de lo no perlocucionario. Sin percatarse que su arcaica posición, produce desgano, represión, esterilidad e indiferencia, y aunque posiblemente permita entender, no nos motiva a actuar en consecuencia.

Posiblemente, la educación no ha logrado hacer de la virtud un hábito que permita a la gente avanzar y comportarse bien por convicción propia, dada la ausencia de la provocación, la 
emoción y la puesta en escena, como elementos liberadores.

De acuerdo con Bauman (2002), en la Modernidad los intelectuales generaban un tipo de conocimiento que legitimaba lo verdadero y lo moral. Este "dar las respuestas correctas" a las preguntas por la realidad de las cosas, convertía a los más destacados de los intelectuales en "legisladores" y al resto en acólitos.

El ethos que ha caracterizado al conocimiento en la época de la modernidad "sólida", centrada en la sociedad del trabajo productivo y el mito del progreso, aumenta cada vez más el déficit de las éticas cognoscitivas. Caracterizada por la liquidez, la educación actual requiere de intelectuales que lejos de entrenar para la permanencia, doten de estrategias para enfrentar la contingencia. Con pedagogías líquidas que incluyan las emociones humanas y den protagonismo al lenguaje, la academia recuperaría la centralidad en la vida social y académica.

De la estrecha relación entre modernidad liquida y lenguaje líquido da cuenta Bauman en su obra Modernidad y holocaustro, en la que a través del término "antisemitismo" que fué acuñado a finales del siglo XIX da un claro ejemplo de la manipulación que sufre el lenguaje cuando es la violencia el que lo genera:

Debido a la inquietud que le acompaña y la indecisión que conlleva experimentamos la ambivalencia como un desorden -ya sea porque el lenguaje tiene carencias que dificultan la precisión terminológica o por un incorrecto empleo lingüístico por nuestra parte. Y, a pesar de todo, la ambivalencia no es producto de cierta patología del lenguaje o del discurso. Se trata, más bien, de un aspecto normal que surge a cada momento en la práctica lingüística. Resulta de una de las principales funciones del lenguaje: la del nombrar y clasificar. Su volumen se incrementa en función de la efectividad con la que estas funciones son realizadas. La ambivalencia es, por tanto, su alter ego, su compañía permanente -de hecho, su condición normal- (http://www. tebeosfera.com).

Bauman no solo se escabulle de las clasificaciones dicotómicas sino que, además, niega y cuestiona el principio de la neutralidad del lenguaje en una sociedad europea del siglo XIX y primera mitad del siglo XX, que marcada profundamente por el lenguaje violento, rendían culto a la manipulación a través del lenguaje del miedo. Continuamos con Modernidad y holocaustro:

A través de la función de nombrar/clasificar, el lenguaje se propone a sí mismo entre un mundo sólidamente fundado y adecuado para la vida humana y un mundo contingente cercado por la arbitrariedad [...]. El lenguaje se esmera en mantener el orden y negar la arbitrariedad inesperada y la contingencia. [...] La situación se torna ambivalente si las estrategias lingüísticas de estructuración resultan inadecuadas, sea porque la situación no corresponde a ninguna de las clases diferenciadas lingüísticamente o porque se encuadra al mismo tiempo dentro de varias clases. [...] Es evidente que la función del lenguaje que consiste en nombrar/ clasificar tiene 
como objetivo la prevención de la ambivalencia (http://books.google.com).

De la no neutralidad del lenguaje en una sociedad líquida y paradójica como la nuestra da cuenta Bauman (2002). Si la sociedad se trasforma a la velocidad del vértigo, si la no neutralidad del lenguaje nos permite surfear en ella ¿Por qué la academia continúa entrenado para la permanencia y la neutralidad del lenguaje?

\subsection{Lenguaje}

\subsubsection{Giro lingüístico}

Que el significado originario del término logos en griego sea "palabra" no es un hecho casual. Con Platón y Aristóteles no obstante, la razón ocupa el lugar del lenguaje y se habla del lenguaje lógico como un lenguaje de primera clase, opuesto al lenguaje literario o retórico como un lenguaje de segunda clase, fué necesario esperar hasta Humboldt, XXIV siglos después, para entender que la razón es el lenguaje como lo sabían los filósofos presocráticos. Nietzsche va a entender que el lenguaje no es exactamente racional, cuando opera una simplificación del mundo desde el punto de vista pragmático, bien sea porque suprime las diferencias al utilizar términos generales, bien sea porque las lenguas más representativas de Occidente son todas de la familia indoeuropea y están comprometidas con una gramática particular. Nietzsche también había dicho, en una célebre fórmula muchas veces citada, que el concepto es una metáfora que ha olvidado que lo es. Lakoff y Johnson se proponen demostrar con eficacia y maestría el acierto de la fórmula nietzscheana. Con su principio de la relatividad lingüística, Whorf hace evidente la no neutralidad semántica y sintáctica del lenguaje, en concordancia con la intuición del célebre pensador alemán. Al utilizar aforismos, al valerse de la metáfora y la ironía, Nietzsche concibe su discurso como dinamita. Es este el filón explotado por Austin cuando advierte que las palabras no solo dicen sino que además hacen.

El valor de las figuras retóricas y de la dimensión connotativa del lenguaje, así como la no neutralidad de la semántica y la sintaxis constituyen los elementos básicos de lo que se conoce hoy día como giro lingüístico, en la medida en que el lenguaje, en la plenitud de sus posibilidades, no limitado por la lógica o el estilo plano, recupera el protagonismo perdido.

Con la no neutralidad del lenguaje a partir del giro lingüístico, las palabras no limitadas a lo denotativo, recuperan su vocación interactiva. El giro lingüístico de Rorty, no solo da cuenta de un mundo contingente, diverso y disperso y rescata el protagonismo del lenguaje en la construcción del conocimiento, sino que, además, advierte que la centralización platónica ignora que el pensar, la cultura, la realidad y la historia son resultados de la contingencia y del azar. Con el uso copulativo del verbo ser colonizando la educación, de espaldas a la variabilidad de los atributos, la academia continúa sustantivando verbos y adjetivos que amplían los campos fantasmagóricos en la educación.

Los pensadores que reivindican el "giro lingüístico", en contraposición al pensamiento metafísico, explicitan la diversidad de léxicos y de mundos, sin olvidar que Bauman coincide 
con ellos al enfatizar en la no neutralidad del lenguaje. En consecuencia, el lenguaje será abordado como medio y acción desde los aportes teóricos registrados por el giro lingüístico, en general, y por la pragmática lingüística, en particular, de cara a los efectos emocionales, así como a los nuevos roles que exige su protagonismo en un mundo evidentemente contingente.

Lejos de verificar la existencia de léxicos universales, hijos de Platón y Aristóteles, filósofos como Wittgenstein y Heidegger han hecho aportes que nos hacen menos ingenuos frente al lenguaje. De la importancia de crear nuevos léxicos y hábitos lingüísticos de cara a la contingencia del mundo actual, da cuenta, entre otros, Frederick Nietzsche.

\subsubsection{Frederick Nietzsche}

La agudeza de Nietzsche lo llevó a dejar al descubierto muchas de las motivaciones que los filósofos habían tratado de ocultar para que su pensamiento diera la impresión de un pensamiento puro fruto de la reflexión imparcial o la razón mecánica. La comprensión del ser humano por Nietzsche no tiene parangón en sus antecesores. Que cambiar al hombre sea condición necesaria para cambiar el mundo, nadie lo discute; pero quizá no sea condición suficiente. A la profundidad del Nietzsche sociólogo, se suele contraponer sus limitaciones a la hora de pensar la sociedad como totalidad.

Al profundizar en la relación pensamiento-lenguaje y utilizar con largueza la metáfora, la ironía, la paradoja, el aforismo, inclusive, Nietzsche se erige en el precursor del giro lingüístico. Todo lo cual marca un hito en la historia de la filosofía en general, y del lenguaje, en particular, como no solo puede verificarse en sus ideas, sino, además, en su escritura.

Que el dominio del lenguaje sobre el pensamiento se le atribuya a Nietzsche, no resulta extraño cuando logra desmantelar el engaño del pensamiento metafísico al asumir el lenguaje como inerte y universal. Tan pronto los pensadores a partir de Nietzsche empiezan a tomar distancia de la tradición metafísica, hija de la escritura, uno tras otro los dualismos acumulados a través de la historia son puestos en cuestión.

Caracterizado por su lenguaje sugestivo, impactante, insinuante y provocador, Nietzsche es la puerta que antecede a todo un vasto campo de nuevas consideraciones sobre el lenguaje, entre otros, Benjamin Lee Whorf, John Langshaw Austin, George Lakoff y Mark Johnson, quienes ampliaron su panorama de posibilidades en el plano del lenguaje.

Nietzsche hace sus apuestas en torno a la relación entre la filosofía y el lenguaje. Con la expresión "toda la historia del pensamiento occidental puede ser resumida como un capricho del lenguaje", se anticipa a Wittgenstein, cuando aduce que los problemas filosóficos surgen cuando el lenguaje hace una fiesta o se va de vacaciones. Ambas posiciones filosóficas dan cuenta de la coincidencia de estos dos pensadores que defienden los efectos pragmáticos del lenguaje, es decir, la constante interacción entre pensamiento y acción, y rechazan la idea del significado como algo fijo y eterno, o como una mera propiedad del análisis lógico. 
Del lenguaje como una relación compleja de metáforas, símiles y licencias poéticas, y de su sometimiento al contexto variable de una comunidad de hablantes, da cuenta el autor de Así habló Zaratustra cuando sostiene que los lenguajes son formas de vida, en el sentido de que "toda lengua condensa y alberga en su estructura un modo idiosincrático de ver la realidad y de entender la vida, uno entre otros muchos posibles" (Nietzsche, 2005). Lejos de ser convencionalidad pura, el lenguaje no tendría definiciones, sino, usos, como fuera expuesto por Wittgenstein. Con capacidad creadora, el hombre inventa nuevos lenguajes que no son copias de la realidad, porque lenguaje y realidad se crean mutuamente. El sentido de realidad al que aquí aducimos está directamente relacionado con las realidades individuales, subjetivas y colectivas, que dan sentido a las personas y que pueden coincidir o no con otras realidades.

Si la realidad es el devenir, y el lenguaje no solo da cuenta del mundo sino que, además, nos permite interactuar con él; el lenguaje, en general, y la metáfora, en particular, no sometidos a la metafísica, amplían nuestros horizontes de sentido y permite reconocernos como seres con diferentes campos semánticos, como en efecto lo refiere Nietzsche en Sobre verdad y mentira en sentido extra moral:

El impulso a la elaboración de metáforas, ese impulso fundamental del hombre, que no puede ser eliminado ni por un instante porque ello significaría la eliminación del hombre mismo, no por haberse construido con sus productos volatilizados, los conceptos, un mundo nuevo, regular y rígido, para que le sirva de castillo fuerte, está realmente dominado, apenas sí domado (Nietzsche, 1990).

Señalando la metafísica como la muerte en vida, Nietzsche nombra el destino de dos milenios de historia occidental, luego de los cuales según nuestro autor, empezaremos a vivir el nihilismo. Apuesta a la cultura para salir de la oscuridad metafísica e iluminar la educación por medio de la metáfora como máquina desacralizadora y detonante de la emoción:

¿Qué es, pues, verdad? Respuesta: una multitud movible de metáforas, metonimias $\mathrm{y}$ antropomorfismos, en una palabra una suma de relaciones humanas poéticas y retóricamente potenciadas, transferidas y adornadas que tras prolongado uso se le antojan fijas, canónicas y obligatorias a un pueblo. Las verdades son ilusiones que se han olvidado que lo son, metáforas astadas cuya virtud sensible se ha deteriorado, monedas que de tan manoseadas han perdido su efigie y ya no sirven como monedas, sino como metal (Nietzsche, 1990).

Que el lenguaje conceptual, hijo de la lógica dogmática, pretenda ser un reflejo de la realidad, que la metáfora y la ironía no solo sean lenguajes del arte, sino, además, de la ambivalencia cotidiana, y que Nietzsche no solo dice, sino que explota, es la conexión de Austin (1971) con Nietzsche, la misma que se registra cuando en Cómo hacer cosas con palabras, rechaza el lenguaje como elemento estático libre de contextos.

La influencia nietzscheana en el relativismo lingüístico de Benjamín Lee Whorf, se hace evidente cuando señalada la gramática como "nociva y metafísica", refiriéndose a la gramática 
de las lenguas indoeuropeas, leemos en Más allá del bien y del mal:

El asombroso parecido de familia de todo filosofar indio, griego, alemán, se explica con bastante sencillez. Justo allí donde existe un parentesco lingüístico [...] en virtud del dominio y la dirección inconscientes ejercidos por funciones gramaticales idénticas, todo se halle predispuesto de antemano para un desarrollo y sucesión homogéneos de los sistemas filosóficos (Nietzsche, 2000, pp. 44).

Habiendo precisado Nietzsche en Sobre verdad y mentira en sentido extra moral, que el concepto es una metáfora que ha olvidado que lo es, Lakoff y Johnson se ponen en la tarea de hacer evidente la ubicuidad de la metáfora, no solo en el lenguaje literario, sino, además, en el lenguaje cotidiano.

En síntesis, a partir de Nietzsche surgieron otras formas de usar, entender y percibir el lenguaje, que hasta el giro lingüístico la academia, en general, ignora. La pragmática lingüística de Benjamin Whorf, la concepción del lenguaje en situación pragmática como acto de habla de Austin (1971) y el poder de las metáforas desarrollado por Lakoff y Johnson, por nombrar algunos, son ejemplos prototípicos de su lucidez. Veamos en breves palabras, cual fué el aporte de cada uno de ellos al giro lingüístico.

\subsubsection{Benjamin Whorf}

Habiendo permanecido y discutido desde Aristóteles, el dualismo pensamiento- lenguaje fué rebatido por Whorf. No pensamos al margen del lenguaje sino a través suyo, y en particular, de las palabras que usamos y la sintaxis que la gobierna. Habiendo formulado el principio de relatividad lingüística, Whorf adoptó una posición determinista en torno a la relación lenguaje-pensamiento. Fue una posición exagerada. Aunque el lenguaje no es neutral, difícilmente podríamos comprometernos con una posición determinista y el común de los autores interesados en el tema únicamente reconocen que el lenguaje condiciona el pensamiento.

La relatividad lingüística (la no neutralidad de la gramática y el léxico) es uno de los aportes más significativos al lenguaje en los últimos tiempos. La idea del pensamiento condicionado, cuando no determinado por el lenguaje, debería ser razón suficiente para repensar la educación y sus estratagemas, de tal suerte que sea traído de la periferia y recupere su centralidad en el acto educativo; dando paso a la pluralidad y a la provocación de las figuras retóricas.

Al igual que Nietzsche, Whorf, defiende la presencia de la metáfora en el lenguaje, incluso las usamos sin darnos cuenta. Leemos en Lenguaje, pensamiento y realidad:

Para acoplarse a una gran diversidad de situaciones actuales, todas las lenguas necesitan expresar duraciones, intensidades y tendencias. Las lenguas SAE y quizás muchos otros tipos de lenguas, tienen las características de expresarlas metafóricamente. Las metáforas son las que corresponden a extensión espacial, o sea tamaño, número (pluralidad), posición, forma y movimiento. Expresamos la duración con palabras tales como «largo, corto, enorme, mucho, rápido, despacio», etc.; la intensidad con 
«grande, mucho, pesado, luz, alto, bajo, agudo», etc.; la tendencia con «más, aumento, crecimiento, aproximación, ir, venir, aumentar, caer, detener, rápido, despacio», etc. Esta lista de metáforas podría hacerse interminable; sin embargo, difícilmente las reconocemos como tales, ya que son virtualmente los únicos medios lingüísticos disponibles. Los términos no metafóricos existentes en este campo, como "pronto, tarde, intenso, mucho, tendencia» no son más que un puñado, bastante inadecuado para las necesidades (Whorf, 1971, pp. 167 - 168).

De la misma forma, Whorf establece así un principio de relatividad por el cual una persona no es libre de clasificar el mundo como lo percibe, sino, como la lengua socialmente construida se lo impone; para ilustrarlo enfrenta la unidad de las lenguas indoeuropeas con la diversidad de las lenguas indígenas americanas. Leemos en Lenguaje, pensamiento y realidad:

[...] También me di cuenta de que incluso la gramática hopi tenía una relación con la cultura hopi, mientras que la gramática de las lenguas europeas tenía relación con nuestra propia civilización "occidental" o "europea". También me di cuenta de que las interrelaciones quedaban contenidas en esas amplias clases de experiencias del lenguaje que nos proporcionan términos como "espacio", "tiempo", "sustancia" y "materia”. Así, pues, y respecto a los rasgos comparados, existe muy poca diferencia entre el inglés, el francés, el alemán o cualquier otra lengua europea [...] por lo tanto, agrupé a estas lenguas en un grupo que llamé SAE o Standard Average European (pp. 160).

Que el universalismo cultural del que somos herederos se refleje en nuestro lenguaje, nos obliga a tomarlas en consideración en la educación a riesgo de fosilizarnos si no lo hacemos.

\subsubsection{John Langshaw Austin}

El lenguaje no solo nos permite dar cuenta del mundo sino, además, coordinar acciones. De allí la distinción formulada por Austin entre lo constatativo y lo realizativo. En particular, las expresiones realizativas no son verdaderas ni falsas, sino que son afortunadas o infortunadas.

Con Austin se da un giro pragmático en virtud de los actos de habla dado que el lenguaje asume carácter de acción "decir algo es hacer algo", ejemplo: “tráeme el vaso". Leemos en Cómo hacer cosas con palabras:

Cuando alguien dice algo debemos distinguir: a) el acto de decirlo, esto es el acto que consiste en emitir ciertos ruidos con cierta entonación o acentuación [...] acto ilocucionario, o la dimensión locucionario del acto lingüístico; b) el acto que llevamos a cabo al decir algo: prometer, advenir, afirmar, felicitar, [...] acto ilocucionario [...]. c) el acto que llevamos a cabo porque decimos algo: intimidar, asombrar, convencer, ofender, esto es acto perlocucionario (Austin, 1971, pp. 32). 
Aunque se presentan de manera simultánea, las propiedades de ambos tipos de enunciado son diferentes. Si el acto locutivo posee significado; si el acto ilocutivo permite coordinar acciones; y si el acto perlocutivo logra efectos; los actos de habla se podrían resumir en dos frases: en virtud del protagonismo del contexto, con el lenguaje no solo se describe el mundo sino que, se hacen cosas y las oraciones, aunque compartan el contenido proposicional pueden significar cosas en virtud de su fuerza, efectos y consecuencias.

Nadie discute la existencia de los enunciados perlocucionarios que fueron formulados por Austin en Cómo hacer cosas con palabras. Que las palabras no solo dicen, sino que, además, motivan, enojan, despiertan, agreden, no está en discusión. Formular un listado de los verbos perlocucionarios como hace Austin, puede resultar un resabio lingüístico, cuando la pragmática nos enseña que los enunciados que en un contexto son perlocucionarios, en otro pueden ser simplemente locucionarios.

Si el lenguaje es más que sonidos, reglas gramaticales y palabras, si los contextos construidos y compartidos entre emisor y receptor favorecen la trasmisión del mensaje y determina en gran medida las consecuencias de los actos de habla, la pragmática lingüística permitiría entender lo dicho (lo que el emisor quiere decir) y lo trasmitido (lo que el receptor comprendió). La pragmática libera al lenguaje de la neutralidad y permite que el significado de las palabras dependa de su relación con los hablantes y los contextos, no de su significado.

Que no siempre nuestras palabras digan lo que queremos decir, que la cercanía entre lo que quiero decir y lo que los demás entienden, dependa del contexto, demuestra que la pragmática nos hace menos ingenuos frente al lenguaje.

Si las palabras no solo dicen, sino que, hacen, si el contexto cobra protagonismo, es menester que la academia adelante un giro que recupere la centralidad del lenguaje, no solo por su poder para hacer, sino, además, por sus múltiples connotaciones individuales y sociales. Leemos en Emociones y lenguaje en educación y política de Maturana:

Necesito mi cerebro para estar en el lenguaje, tengo un cerebro que es capaz de crecer en el lenguaje, pero el lenguaje no se da en el cerebro. El lenguaje como fenómeno, como un operar del observador, no tiene lugar en la cabeza, ni consiste en un conjunto de reglas, sino que tiene lugar en el espacio de relaciones y pertenece al ámbito de las coordinaciones de acción como un modo de fluir en ellas, no como algo en citas. Si cambia mi estructura, cambia mi modo de estar en relación con los demás y, por lo tanto, cambia mi "lenguajear". Si cambia mi "lenguajear", cambia el espacio del "lenguajeo" en el cual estoy y cambian las interacciones en que participo con mi "lenguajeo" (Maturana, 1990, pp. 29).

Reflexionar sobre el lenguaje, es estar en él. Sabemos que el mundo ha cambiado, que hay apuestas y no caminos ni certezas, que la emoción hace parte de las funciones de nuestro sistema nervioso; de ser reprimida, quedamos sin motivación, desmejorando la memoria, si no es que la desparece. Reconocer el poder de la emoción en la memoria, y la contingencia del 
mundo actual, resulta perentorio. El conocimiento debe motivar para no terminar olvidado.

Al margen de la emoción, la razón dice; en conexión con ella, no solo dice sino, que además, hace. Leemos en Cómo hacer cosas con palabras de Austin:

[...] Es menester que reconsideremos de un modo más general los sentidos en que decir algo puede ser hacer algo, o en que al decir algo hacemos algo y también, quizá, considerar el caso diferente en que por decir algo hacemos algo (Austin, 1996, pp. 135).

No solo hay que evitar la falta de emoción sino, además, las emociones que generalmente pueden llegar a ser negativas, es decir, las que pudieran malograr el proceso educativo como el desánimo, el desinterés, el miedo y la presión por mencionar algunos. Sin embargo, existen emociones que aunque son llamadas negativas, hacen parte sustancial de la vida misma y pierden su naturaleza negativa cuando salvan nuestra vida. Es posible, por ejemplo, que al miedo le debamos nuestra integridad física, cuando evitamos un peligro.

\subsubsection{Lakoff \& Johnson}

Metáforas de la vida cotidiana de George Lakoff y Mark Johnson, marcó un hito en la concepción y uso del lenguaje metafórico en el campo de las humanidades. Lejos de ser propio de la imaginación poética y ademanes retóricos que ignoran las realidades, la metáfora impregna la vida cotidiana, es decir, no es solo lenguaje, sino, además, pensamiento y acción. Leemos en el mencionado libro:

La metáfora no está meramente en las palabras que usamos, está en nuestros mismos conceptos [...]. La afirmación más importante que hemos hecho hasta ahora es que la metáfora no es solamente cuestión de lenguaje, es decir, de palabras meramente. Sostenemos que, por el contrario, los procesos del pensamiento humano son en gran medida metafóricos. Las metáforas como expresiones lingüísticas son posibles, precisamente, porque son metáforas en el sistema conceptual de una persona (Lakoff \& Johnson, 1995, pp. 42).

Que usemos metáforas en nuestro lenguaje, que dependan del contexto, que el sistema conceptual estructure nuestras percepciones del mundo y relaciones sociales, es la prueba que nuestro pensamiento y acción son igualmente metafóricos, porque comparten el mismo sistema conceptual.

En virtud de la metáfora como instrumento provocador, que permite expresar lo abstracto a partir de lo concreto, comprendemos un ámbito de nuestra experiencia en términos de la estructura de otro ámbito de experiencia, es decir, hacer transacciones de sentido entre contextos, ampliando las posibilidades de comprensión.

Especial interés merecen las metáforas ontológicas en la clasificación de Lakoff y Johnson en 
la medida en que nos permiten reconocer el origen lingüístico de los más célebres conceptos metafísicos que no solo son muchas veces adjetivos o verbos sustantivados sino que, además, proceden de cosas concretas, y una vez más hemos olvidado que lo son.

Que la metáfora desencadene procesos, que amplíe horizontes de sentido, que detone la emoción, serían razones suficientes para darle protagonismo en la educación. Que a través de la metáfora se exprese el devenir como realidad, que las metáforas provoquen excitaciones nerviosas porque emocionan, serían coincidencias entre estos dos pensadores estadounidenses y Frederick Nietzsche. En síntesis, el poder de la metáfora se extiende al funcionamiento de nuestro cerebro.

La reivindicación de las metáforas culturales trasciende el estrecho marco de la literatura a la que había sido confinada. Lakoff y Johnson demuestran que Nietzsche tenía razón cuando decía que un concepto no es más que una metáfora que ha olvidado que lo es, hasta aquí no hay discusión. No obstante, Lakoff y Johnson dan un paso más adelante cuando sostienen que las metáforas que utilizamos prefiguran nuestra manera de pensar y de actuar. Tesis excesiva, por supuesto. Caeríamos en un determinismo lingüístico todavía más excesivo que el de Whorf.

\subsection{Filosofía}

Que los sociólogos reconozcan el protagonismo de la emoción, que los publicistas se aprovechen de ella, que con el tránsito de la lingüística a la pragmática lingüística, su protagonismo sea indiscutido es uno de los signos de nuestro tiempo. La filosofía no podía ser la excepción. Así haya sido concebida como la actividad racional por excelencia en el marco de una tradición que va de Platón al positivismo, no han dejado de haber pensadores que reivindiquen la pasión, el instinto, cuando no la sensibilidad, el sentimiento, y por supuesto la emoción. Pascal, Rousseau y Nietzsche entre ellos. No faltan los autores más recientes, no es la razón, ni siquiera la argumentación la que los une, sino la simpatía, de acuerdo con Adam Smith. John Dewey da un paso más delante cuando reconoce en el arte la fuerza de una emoción que convoca, cuando no es que sorprende. Que la educación deba aprender del arte es una consecuencia derivada de semejante afirmación. Si la emoción es propia del arte, lo es por supuesto del hombre y esta es la pista seguida por Strawson cuando reconoce en los sentimientos morales la vía por excelencia para superar el déficit motivacional de las éticas cognoscitivas. Nussbaum, por último, no solo quiere utilizar el arte para otros fines que lo trascienden como Adam Smith, sino, además, utilizar las emociones para el mejoramiento moral de la humanidad en concordancia con Strawson.

\subsubsection{Adam Smith}

Un ser benévolo, armonioso y naturalmente compasivo que busca "la mayor cantidad posible de felicidad" explicaría las apuestas de Smith por la vida moral del hombre. La simpatía de acuerdo con Smith, es el don de vernos a nosotros mismos como los demás nos ven: es la capacidad de convertirnos en espectadores imparciales de nosotros mismos y de aprobar o 
desaprobar nuestra conducta, la misma que estaría acorde a los requerimientos sociales. Lo que ha llamado "yo apreciador y juez", nos obliga a reconocer la multiplicidad de papeles que desempeñamos no solo en la vida personal y familiar, sino, además, en la vida social.

Convertidos en espectadores a través de la simpatía, desempeñaríamos doble papel: el de la persona cuyos sentimientos intento aprehender, poniéndome en su lugar y considerando desde él mi conducta y el "yo" como persona que intenta juzgar desde el punto de vista del espectador”. De acuerdo con Smith, esta doble tarea no resultaría difícil, toda vez que el ser humano es bueno por naturaleza. Leemos en Teoría de los sentimientos morales:

Por más egoístas que quiera suponerse al hombre, evidentemente hay algunos elementos en su naturaleza que lo hacen interesarse en la suerte de los otros, de tal modo que la felicidad de estos le es necesaria, aunque de ello nada obtenga, a no ser el placer de presenciarla. De esta naturaleza es la lástima o compasión, emoción que experimentamos ante la miseria ajena, ya sea cuando la vemos o cuando se nos obliga a imaginarla de modo particularmente vívido. El que con frecuencia el dolor ajeno nos haga padecer, es un hecho demasiado obvio que no requiere comprobación; porque este sentimiento, al igual que todas las demás pasiones de la naturaleza humana, en modo alguno se limita a los virtuosos y humanos, aunque posiblemente sean estos los que lo experimenten con la más exquisita sensibilidad. El mayor malhechor, el más endurecido transgresor de las leyes de la sociedad, no carece del todo de ese sentimiento (Smith, 1759, pp. 29).

Si el cerebro reptil humano, está programado con sentimientos de afinidad y bondad frente a los demás ¿qué sucede con la sociedad actual? ¿Por qué los altos índices de intolerancia y violencia? La violencia de la sociedad actual rechaza todo intento de acuerdo moral y emocional. La disyuntiva se da cuando pretendemos solucionar con la razón los desacuerdos emocionales.

Lejos de brindar protagonismo a la razón o a los sentidos que no solo pueden llegar a engañarnos, sino que, además, impide la introspección y sensibilizarnos emocionalmente frente a los demás, la imaginación nos permite un mejor acercamiento a las sensaciones ajenas (tal y como lo sustenta Martha Nussbaum cuando defiende el cine y la literatura). Continuamos con Teoría de los sentimientos morales:

Nuestra imaginación tan solo reproduce las impresiones de nuestros propios sentidos, no las ajenas. Por medio de la imaginación, nos ponemos en el lugar del otro, concebimos estar sufriendo los mismos tormentos, entramos, como quien dice, en su cuerpo, y, en cierta medida, nos convertimos en una misma persona, de allí nos formamos una idea de sus sensaciones, y aun sentimos algo que, si bien en menor grado, no es del todo desemejante a ellas. Su angustia incorporada así en nosotros, adoptada y hecha nuestra, comienza por fin a afectarnos, y entonces temblamos y nos estremecemos con solo pensar en lo que está sintiendo. Porque, así como estar sufriendo un dolor o una pena cualquiera provoca la más excesiva desazón, del mismo 
modo concebir o imaginar que estamos en el caso, provoca en cierto grado la misma emoción, proporcionada a la vivacidad u opacidad con que lo hemos imaginado (Smith, 1759, pp. 30 - 31).

El objetivismo de acuerdo con Smith, es una falacia que ha hecho carrera. No es posible desprendernos de nuestras creencias y juicios de valor para juzgar los sentimientos de otros. Si al tomar el lugar del otro, siento algo que parece semejante a lo que él siente, estoy aprobando su sentimiento desde mi sentimiento. Ser menos ingenuos frente a los sentimientos, nos haría mejores seres humanos y reduciría la crisis silenciosa de la que habla Nussbaum y que por supuesto nos incumbe al cultivar determinadas habilidades humanas y desechar otras.

Finalmente, es cierto que Adam Smith reivindica el valor de las emociones en la cotidianidad, pero no menos cierto es que el liberalismo económico propuesto por él, lo compromete con el racionalismo a ultranza, cuando atender el interés individual por parte de todos y cada uno de los integrantes de la sociedad produciría automáticamente el bienestar de todos sin mediar una acción redistributiva del estado. El capitalismo, se convierte en una especie de maquinaria que actúa por su propia inercia y no da protagonismo alguno a la emoción. En contravía con las pretensiones de Adam Smith, ese capitalismo mecanicista, lo que produjo fue una creciente desigualdad.

\subsubsection{John Dewey}

Los intelectuales siglo tras siglo abundan en críticas al Estado de cosas vigentes, las más de las veces ciertas. Sus propuestas de cambio, no obstante, pocas veces terminan teniendo éxito. Es cuando surge el pragmatismo, de acuerdo con el cual solo las teorías que efectivamente conduzcan al cambio pueden ser consideradas verdaderas. El pragmatismo termina siendo "realista" en el mejor sentido de la palabra, pero corre peligro al mismo tiempo, de hacer de la historia un tribunal de última instancia y de confundir el bien con los hechos, en síntesis, corren el riesgo de ser maquiavélicos.

Aunque la autosuficiencia de la razón en el proceso educativo, ha sido un ideal al que no pocos pensadores se han adherido a través de los tiempos, es evidente que en las últimas décadas, cuando el mundo se acelera y las certezas hacen crisis, se demanda mayor flexibilidad, más interacción, inclusive, lo que llevaría a destacados intelectuales a rescatar el protagonismo de la emoción, como en efecto haría Dewey en El arte como experiencia: "la emoción es la fuerza móvil y cimentadora; selecciona lo congruente y tiñe con su color lo seleccionado, dando unidad cualitativa a materiales exteriormente dispares y desemejantes" (Dewey, 1934, pp. 49).

Con doctorado en represión y lenguaje plano, la academia se limita a entrenar para la permanencia y alimentar el lastre del discurso denotativo que ajeno a las posibilidades interactivas de la comunicación, sume al estudiante en la literalidad y lo aleja de su sensibilidad y naturaleza poética: 
EI animal viviente no tiene que proyectar sus emociones en los objetos que experimenta. La naturaleza es amable y odiosa, suave y taciturna, irritante y confortante, mucho antes de que sea matemáticamente calificada, o aun aparezca como un conjunto de cualidades "secundarias", los colores y sus formas. Incluso palabras tales como largo y corto, sólido y hueco, tienen todavía una connotación moral y emocional, excepto para aquellos que se han especializado intelectualmente (Dewey, 1934, pp. 17).

No se trataría de operar el relevo de la razón por la emoción, sino de recuperar su dinámica, su diálogo propiamente dicho. Siguiendo con Dewey: "no es posible dividir con una experiencia vital, lo práctico, lo emocional e intelectual y enfrentar las propiedades de uno con las características de otros. La base emocional liga a las partes en un todo” (pp. 63).

El Arte como experiencia de Dewey, es un texto en el que el filósofo norteamericano estaría a tono con los avances en materia de neurofisiología, especialmente con el cerebro triuno de MacLean y los sentimientos morales de Strawson:

[...] y la emoción es un modo de lo sensible [...] somete y digiere todo lo que es meramente intelectual [...]. Aquella intensifica la sacudida emocional y jalona el interés [...]. Saltamos instantáneamente cuando nos asustamos, o nos ruborizamos en el instante en que nos avergonzamos. Sin embargo, el temor y la vergüenza no son, en este caso, estados emocionales. Por sí mismos no son nada más que reflejos automáticos. Para hacerse emocionales deben convertirse en partes incluidas en una situación duradera [...] (pp. 34 - 49).

Que la emoción no necesariamente esté gobernada por la razón y logre jalonar procesos, que el temor sea producto del cerebro reptil de acuerdo con MacLean, y que la vergüenza se produzca al ejecutar una reacción desfavorable hacia otra persona, de acuerdo con Strawson, obligaría a los educadores a ser artistas, toda vez que la emoción es la fuerza que no solo filtra sino que, además, motiva las acciones.

El arte se hace el órgano incomparable de instrucción mediante la comunicación, pero sus procedimientos están muy lejos de los que se asocian generalmente con la idea de educación, se eleva el arte tan por encima de lo que estamos acostumbrados a pensar de la instrucción, que nos repele cualquier sugestión de enseñanza y aprendizaje en relación con el arte. No obstante, nuestra revuelta supone, en efecto, una reflexión sobre la educación, que procede con métodos tan literales que excluyen la imaginación y no tocan los deseos y emociones del hombre (Dewey, 1934, pp. 392).

La experiencia que nos ofrece la obra de arte a partir de una serie de signos o símbolos, convoca la emoción en la medida que nos sorprende, que desborda nuestras expectativas o profana nuestros prejuicios. La experiencia artística puede ser inmediatamente sentida, en virtud de su condición interactiva, de la admiración estética que suscita. Lejos de ser excluida de la academia, debe sacar partido de sus posibilidades a riesgo de quedar anacrónica si no lo hace. La emoción es una fuerza móvil que tiñe con su color una experiencia, que la impregna 
de sentido, unificando sus partes, pero, de otro lado, abriendo el horizonte de posibilidades, en las que sin lugar a dudas, los sentimientos y las actitudes e intenciones hacia los demás favorecen el respeto por las diferencias y motivan la cohesión social, en palabras de Strawson; la clave estaría en pasar de un sistema de reglas socialmente sancionadas a un sistema de reglas morales en el que las personas ya no respetan porque se les obliga a ello o porque les conviene hacerlo, sino porque les interesa respetarlas.

\subsubsection{Peter F. Strawson}

En Libertad y resentimiento, Strawson ha ofrecido una sólida argumentación en contra de la posibilidad de aceptar cabalmente una doctrina determinista y excluyente. Dependiendo de la visión crítica en el ámbito histórico y antropológico, la responsabilidad moral yla mirada interior nos permite reconocer que en los sentimientos morales la razón sola nos hace indiferentes. El lenguaje que usamos para comunicarnos no tendría significado predeterminado, sino, que es adquirido a través de su uso. Strawson busca afincar sus tres actitudes reactivas: resentimiento, indignación, vergüenza, como sentimientos que surgen en el ser humano cuando cree que quien ha actuado de una forma determinada, lo ha hecho de manera libre y espontánea.

En el primer grupo encontramos la gratitud o el resentimiento, estos son sentimientos o reacciones naturales que experimentamos y que dependen de la forma como somos tratados por los demás. Pueden ser justos o injustos, agradables o desagradables. etc. Estas son llamadas actitudes reactivas personales porque nos encontramos directamente involucrados en ellas.

Al primer grupo pertenecen todas aquellas que podrían dar lugar al empleo de expresiones como "No pretendía", "No se había dado cuenta", "No sabía"; y [...] "No pudo evitarlo", cuando este se ve respaldado por frases como "Fue empujado", "Tenía que hacerlo", "Era la única forma", "No le dejaron alternativa”, [...] ninguna de ellas invita a que suspendamos nuestras actitudes reactivas hacia el agente, ni en el momento de su acción, ni en general. [...] No invitan a que veamos al agente más que como agente plenamente responsable. Invitan a que veamos la ofensa como cosa de la cual él no era plenamente, o ni siquiera en absoluto, responsable. [...] Simplemente, el agente ignoraba el daño que estaba causando (Strawson, 1962, pp. 44).

Cada una de estas excusas hace que el agente tome una nueva posición frente al daño causado o favor recibido. Que el resentimiento se pueda neutralizar de dos maneras diferentes (caer o hacer en la cuenta que el sujeto que me causó la ofensa carece de responsabilidad moral o señalar una disminución de la responsabilidad del ofensor: "estaba sometido a una gran presión”) sería la clave para aumentar los niveles de moral social y disminuir los de violencia. De acuerdo con Strawson, el resentimiento, es la actitud más importante y sobre la cual debemos centrar nuestros esfuerzos. Nuestra actitud frente a los acontecimientos, determinarían el futuro de la sociedad.

La indignación, pertenece al segundo grupo. Es una actitud $o$ sentimiento reactivo en el que no nos hallamos directamente relacionados como sucedía en el primer grupo. Esta actitud nacerá de lo que sentimos por lo que le sucede injustamente a alguien más. 
El segundo grupo de consideraciones es muy diferente. Las dividiré en dos subgrupos, [...] el primero [...] enunciados como "No era él mismo", Últimamente se ha encontrado bajo una gran presión. [...] El segundo y más importante subgrupo de casos permite que las circunstancias sean normales, pero nos presenta a un agente psicológicamente anormal o moralmente inmaduro. El agente era él mismo, pero se halla deformado o trastornado, era un neurótico o simplemente un niño. Cuando vemos a alguien a una luz así, todas nuestras actitudes reactivas tienden a modificarse profundamente (pp. 45 - 46).

En una sociedad individualista como la actual en la cual el consumismo nos desborda sin importar el dinero que tengamos, con una academia que hace sus mayores apuestas a las competencias en detrimento de sus semejantes (Maturana), sentimientos como los que aquí propone Strawson serían la oportunidad para reaccionar no solo frente a lo que nos sucede directamente, sino, además, en situaciones que afectan a otros fortaleciendo nuestra moral y sentido de alteridad.

La vergüenza, pertenece al tercer grupo de actitudes reactivas, esta hace referencia a nuestro propio comportamiento con respecto a los demás. La vergüenza tiene lugar cuando el sentimiento de haber obrado de manera incorrecta contra alguien cobra sentido. Por lo que reconocemos nuestros errores y buscamos la forma de corregirlo.

De la misma forma que lo explica Adam Smith en su filosofía moral, en la que un Ser con don de simpatía que nos convierte en espectadores imparciales, Strawson hace sus aportes a eudaimonía moral y social a través de su fórmula trial de los sentimientos reactivos: en los que sentimos que alguien ha pecado contra nosotros (resentimiento), que alguien ha pecado contra un tercero (indignación) o que nosotros hemos pecado contra alguien (vergüenza).

Fundamentar la ética en los sentimientos morales es un gran acierto de Strawson. El déficit motivacional de las éticas cognoscitivas explicaría la necesidad de los sentimientos morales en el campo de la acción. El movimiento de los indignados que en las últimas décadas ha ocupado los titulares de los medios de comunicación en numerosos países, es prueba de ello. No basta el argumento para que reaccionemos ante una situación injusta, es necesaria la indignación. El listado de sentimientos morales de Strawson (la indignación, resentimiento y vergüenza) puede parecer, no obstante, caprichoso y está lejos de agotar el repertorio de sentimientos que nos comprometen a diario. ¿Por qué no hablar de aflicción o compasión por ejemplo? ¿Por qué no hacerlo del egoísmo o la benevolencia? Y podríamos concluir con un amplio etcétera.

\subsubsection{Martha Nussbaum. Sin fines de lucro}

Sin fines de lucro, es un valioso aporte de Martha Nussbaum a la sociedad en general, y la educación, en particular, en el que la democracia sería el elemento esencial de la educación socrática. Despertar en las personas la humanidad que cada una posee, sería el anhelo para la educación actual, solo de esta forma estaríamos preparados para afrontar las vicisitudes de un mundo que se renueva a diario. De allí la importancia de la pregunta, el protagonismo 
de la discusión, el debate en el universo de lo público: "Socratic thinking is important in any democracy" (El pensamiento socrático es importante en cualquier democracia) (Nussbaum, 2010, p. 54).

Desde esta perspectiva, la educación debe proporcionar procesos educativos de humanización (Montessori), en lo que también insiste Martha Nussbaum. "If we do not insist on the crucial importance of the humanities and the arts, they will drop away, because they do not make money" (Nussbaum, 2010, p. 143).

¿Cómo prepara el sistema educativo a los niños y jóvenes para la vida en una organización democrática moderna en la que sus integrantes son diferentes? Partiendo de este interrogante, y con la convicción de que ninguna democracia puede ser estable si no cuenta con el apoyo de los ciudadanos educados para ese fin, Martha Nussbaum se preocupa por los fines de la educación en un contexto educativo que apuesta por la competitividad y racionalidad instrumental en detrimento de las artes y la humanidades como posibilidades infalibles de acceder a una mejor sociedad y calidad educativa.

Con el protagonismo de la "educación para la renta" en detrimento de la "educación para la democracia”, Nussbaum comprende el oscuro presente y futuro educativo y social. Con la pedagogía de la investigación, las preguntas y la indagación, el estudiante estaría entrenado para el cambio y no para la permanencia; para la reflexión y la argumentación y no para el sometimiento a la tradición y a la autoridad.

Reflexionar sobre los graves problemas existenciales y los males sociales de la época contemporánea resulta determinante. Repensar las prácticas pedagógicas y poner en tela de juicio ciertas posturas de antaño que desconectan la emoción con la razón y disfrazan el desfase social y educativo, resulta inaplazable.

Los argumentos que suscriben o rechazan propuestas en la búsqueda por despertar la humanidad o luchar contra las injusticias sociales propuestos por Martha Nussbaum, cuentan con toda nuestra simpatía. Mejorar nuestras capacidades de agentes morales racionales, y ensanchar los horizontes de justicia para lograr un modelo de sociedad más justo y compasivo, resulta determinante. Que el cine y la literatura sean las estratagemas específicas para alcanzar las mencionadas apuestas son un aporte significativo al ámbito educativo. Sin embargo, Nussbaum parece dejar al cine en un segundo plano cuando centra todos sus esfuerzos en la literatura y se queda corta en la argumentación que hace sobre el uso e importancia del cine en la educación. Si el cine, a diferencia de la literatura, accede a nuestro cerebro por medio de más sentidos (visión, audición y tacto en algunos casos), ¿por qué relegarlo a un segundo lugar? 


\section{La reivindicación de la Emoción}

\subsection{La ciencia no se detiene}

En un mundo acelerado que se renueva a la velocidad del vértigo, la reivindicación de la emoción resulta perentoria. La coexistencia de varias culturas en un mismo espacio no solo físico, sino, además, mental, exige repensar los fines educativos y la adopción de estrategias integradoras ante la diversidad cultural, étnica y lingüística. Para moverse en un mundo unificado (educación 1) se necesitan mapas, pero para moverse en un mundo cambiante y diverso como el actual (educación 2), se necesita olfato, sensibilidad, motivación, disposición para el cambio y habilidad para la adaptación.

Con doctorado en represión emocional, la academia continúa dividiendo lo que por naturaleza está unido. Se parcelan el mundo y el hombre, se sacraliza la especialización y se adopta una concepción mecanicista del currículo, fundada en un conductismo acrítico por supuesto. La intolerancia y la violencia registrada en la sociedad actual es una de sus consecuencias. Detenerse a pensar en "qué se está haciendo", “cómo se está haciendo" "con quién se está haciendo" y "para qué se está haciendo", resulta perentorio. Constituida por la multiplicidad, la condición humana no puede ser reducida a la uniformidad.

Los nuevos desarrollos intelectuales y culturales proporcionan una serie de estrategias y avances científicos particularmente útiles a la hora de repensar la educación. Nos interesan específicamente, los relacionados con prácticas liberadoras e interactivas y los adelantos neurofisiológicos relacionados con la conexión emoción-razón como se explica a continuación:

- Opuestas a la educación repetitiva y bancaria, las prácticas liberadoras propuestas por Paulo Freire. En su condición de lastre, la educación que reprime la vocación interactiva del hombre, que opera como lastre debe ser superada. No faltan las vías al respecto. De la literatura y el cine como estrategias eficaces para educar en ciudadanía democrática y despertar en la humanidad y las emociones con fines eudaimonísticos se ocupa Martha Nussbaum, de acuerdo con la cual estos elementos son determinantes para la felicidad interior y la cohesión social que brilla por su ausencia en la actualidad. Augusto Boal propone el teatro del oprimido como una vía para que los estudiantes cambien su rol de espectadores pasivos a espect-actores activos.

- Las recientes investigaciones de Paul MacLean, Antonio Damasio y Joseph LeDoux, por citar algunos, reconocen no solo las bases biológicas de las emociones y su relación con la razón y la conducta humana, sino, que además, destacan como nunca antes el protagonismo de la emoción. Howard Gardner, se ocupa de las diversidad humana que se hace evidente en la teoría de las inteligencias múltiples. Lejos de limitarse a la razón, las decisiones lógicas estarían poderosamente influenciadas por la emoción, de acuerdo con Humberto Maturana y Joseph LeDoux. Luis Carretié, de otro lado, fórmula la anatomía de la emoción y la cognición en la que 
las emociones facilitarían la adaptación y la motivación del individuo toda vez que las redes neurales subyacentes a la emoción incluyen conexiones directas con el sistema motivacional primario. En síntesis, lejos de ser excluyentes, la emoción y la razón, mantienen relación de cooperación que la academia separa.

\subsection{Antecedentes en la educación. Prácticas liberadoras}

\subsubsection{Paulo Freire: pedagogía del oprimido, pedagogía de la autonomía}

Sostener la existencia de certezas, cartilla, mapas, cuando no de verdades, en síntesis, de modelo de educación bancaria, es el resultado de una universidad que ofrece sus servicios a la religión inicialmente, pasado por el Estado y finaliza al servicio del crecimiento económico.

Si el ser humano participa de diferentes prejuicios y está comprometido con diversas expectativas, el mundo social es plural. De allí el compromiso de la educación con el pluralismo, por lo menos en teoría. En la práctica, en cambio, no faltan los intentos de utilizar la educación como instrumento político. En la educación, de acuerdo con Freire, abunda la acción anti dialógica, centrada en la necesidad de conquista y dominio de una de las partes en detrimento de la otra Leemos en Pedagogía del Oprimido:

El educador que aliena la ignorancia, se mantiene en posiciones fijas, invariables. Será siempre el que sabe, en tanto los educandos serán siempre los que no saben. La rigidez de estas posiciones niega a la educación y al conocimiento como procesos de búsqueda (Freire, 1970, p. 52).

Con la pedagogía de la respuesta en detrimento de la pedagogía de la pregunta, los docentes se confabulan para perpetuar su función opresora y descontextualizada "contestar a preguntas que los estudiantes no han formulado (Freire). El papel del docente, en el mundo contemporáneo se limita al de fiduciario.

El educador se enfrenta a los educandos como su antinomia necesaria. Reconoce la razón de su existencia en la absolutización de la ignorancia de estos últimos. Los educandos, alienados a su vez, a la manera del esclavo, en la dialéctica hegeliana, reconocen en su ignorancia la razón de la existencia del educador pero no llegan, ni siquiera en la forma del esclavo en la dialéctica mencionada, a descubrirse como educadores del educador [...]. La educación liberadora, ya no puede ser el acto de depositar, de narrar, de transferir o de trasmitir «conocimientos» y valores a los educandos [...] como lo hace la educación «bancaria», sino ser un acto cognoscente. [...] El papel del educador es el de proporcionar, conjuntamente con los educandos, las condiciones para que se dé la superación del conocimiento al nivel de la «doxa» por el conocimiento verdadero, el que se da al nivel del «logos» (pp. 52 - 62).

El primado de la instrucción, la clonación de maestros ignorantes (Ranciére), que perpetúan 
la deshumanización y la desconexión de la emoción con la razón, las facultades e instalaciones separadas, los timbres, la organización por grupos por edad y género, inclusive, evidencian el primado de una educación con fines industriales que hoy se imparte en los países de Occidente. El protagonismo de lo económico sobre lo humano, nos hace vulnerables a la deshumanización. Resulta determinante contar con maestros que lejos de educar con moldes y paradigmas, recuperen el derecho a pensarnos en la individualidad, en la pluralidad y en el reconocimiento del otro.

De la misma forma que el movimiento de los indignados rechazó la opresión de un bipartidismo con características vitalicias, Paulo Freire rompió con el silencio y luchó contra la pasividad y el silencio a través de elementos de corte marxista para la visión y comprensión de la historia. La pedagogía del oprimido, la pedagogía de la pegunta y la crítica a la educación repetitiva y bancaria son un legado freiriano que permite vislumbrar la sombra a la cual ha sido relegada la educación. Sin embargo, que el método de Freire se fundamente en la cultura popular, que, a su vez, se traduce en una política popular, corre el riesgo de confundir los planos político y pedagógico.

El aporte teórico de Freire a la anti opresión social y educativa, ya desde la autonomía, ya desde la pedagogía, fue extendido y trasformado en una herramienta pedagógica por el también brasilero Augusto Boal a través del teatro del oprimido.

\subsubsection{Augusto Boal: teatro del oprimido}

El Teatro del Oprimido ( $\mathrm{TdO}$ ) es una tendencia teatral sistematizada por el actor, director y pedagogo teatral brasileño Augusto Boal entre los años 1950 y 1960. Este dramaturgo no solo profundizó en la Teoría del oprimido de Paulo Freire, sino, además, en la historia del teatro. En su obra Theatre of the oppressed se puede evidenciar:

Aristotle was so amazed by his own reasoning, so convinced by it, that he ran home to write a very clever book, to which he gave the delicious title The Poetics - a book which I recommend everyone to read closely. Year after year, century after century, this remained the Official History of Tragedy, and it was a fetter on the explosive Thespian tradition (Boal, 1980, pp. 19).

Las bondades del teatro para desencadenar emociones, como lo evidencia Boal, se ha registrado por lo menos desde Aristóteles quien a través de su Poética aborda la tragedia griega como escenario por excelencia para la imitación a la que llama mímesis. Con el término catarsis, esboza los efectos que la representación de la tragedia produce en la emoción, la imaginación y la conciencia moral del espectador.

En la catarsis, que Aristóteles atribuía exclusivamente a la tragedia, se encuentra la clave para el teatro educativo. Con el drama como rito sagrado y fuente de sabiduría, los griegos, lograron personificar por medio del coro las nociones de "conciencia" y de "razón". Leemos en Theatre of the oppressed: 
Then came the aristocracy and established divisions: some persons will go to the stage and only they will be able to act; the rest will remain seated, receptive, passive - these will be the spectators, the masses, the people. And in order that the spectacle may efficiently reflect the dominant ideology, the aristocracy established another division: some actors will be protagonists (aristocrats) and the rest will be the chorus - symbolising, in one way or another, the mass. Aristotle's coercive system of tragedy shows us the workings of this type of theatre (pp. 23).

Retomando la aspectos de la tragedia griega y la Teoría del oprimido de Paulo Freire, Boal logra poner al servicio de la sociedad y posteriormente de la educación el teatro del oprimido como fórmula liberadora.

\subsubsection{Teatro del oprimido}

Desarrollado en los años 50 y 60, el Teatro del oprimido es una formulación teórica y un método estético, creado por Augusto Boal, con el objetivo fundamental de cambiar el monólogo de la representación tradicional en un diálogo entre el público y el escenario, porque si el diálogo es monólogo, la opresión continúa. El Teatro del oprimido combina diferentes formas artísticas que no solamente se desarrollan en teatro. Lejos de fomentar la mecanización, el teatro del oprimido busca mediante ejercicios, juegos y técnicas teatrales, emancipar físicamente e intelectualmente de las opresiones que están siendo objeto los practicantes, ya de lo político y social, ya de lo educativo. Leemos en Theatre of the oppressed:

[...] the theatre can also be a weapon for liberation. For that, it is necessary to create appropriate theatrical forms. Change is imperative. This work tries to show some of the fundamental changes and how the people have responded to them. [...] a celebration in which all could participate freely (pp. 23).

Por otro lado, esta herramienta pedagógica, tiene por objetivo fundamental utilizar el teatro y las técnicas dramáticas como un instrumento eficaz para la comprensión y la búsqueda de alternativas a problemas sociales e interpersonales. Desde sus implicaciones pedagógicas, sociales, culturales, políticas y terapéuticas se propone transformar al espectador -ser pasivoen-espect-actor, protagonista de la acción dramática -sujeto creador-. El actor al reflexionar sobre su pasado y hacer consciente la situación opresora, puede modificar la realidad del presente y abrir otras opciones de futuro.

De acuerdo con Boal, la primera palabra del vocabulario teatral es el cuerpo humano, lo que abre espacio teatral a cualquier ser humano que busque situaciones de opresión cotidianos y mecanismos de poder en los que está inmerso, para luego buscar alternativas de solución. La condición esencial para que este tipo de teatro tenga lugar, es que el espectador sea el protagonista de la acción dramática y se prepare también a serlo de su propia vida. Del protagonismo asignado al espectador para pensar y actuar, da cuenta Boal cuando se propone producir cultura e ideas, en síntesis, ser artista personal, social e intelectual. 
Todas las formas de teatro deben servir al espectador para salir de su condición de espectador. Él debe ensayar acciones como protagonista de la acción dramática, inclusive si se equivoca. Si se equivoca, se equivoca en la acción y descubre desde su punto de vista que esta acción es mala (pp. 228).

Con el teatro como opción catártica, Boal propone siete técnicas (que ubica en un árbol) para ejecutar el teatro del oprimido. Estas técnicas abren opciones a quienes participan del ritual: Teatro imagen, Teatro periodístico, Arco iris del deseo, Teatro foro, Teatro invisible, Acciones directas, y Teatro legislativo. Leemos en The Aesthetics of the Oppressed:

[...] techniques involving the transformation of journalistic texts into theatrical scenes - consists of the combination of Images and Words to reveal in the former, meanings which are hidden in the latter. [...] The same analytical process occurs with the Introspective Techniques of the Rainbow of Desires which, using words and, especially, images, enables the theatricalisation of introjected oppressions. [...] Forum Theatre: perhaps the most democratic form of the Theatre of the Oppressed and certainly the best known and most practised throughout the world, uses or can use all the resources of all known theatrical forms. Those we call Spect-actors are invited to come on stage and reveal by means of theatre - rather than by just using words - the thoughts, desires and strategies that can suggest, to the group to which they belong, a palette of possible alternatives of their own invention. [...] The Invisible theater can be presented in any location where its drama could really occur or has already occurred (in the street or the square, in the supermarket or the fair, [...] Actors and audience meet on the same level of dialogue and power. Direct Actions (in the context of the Theatre of the Oppressed) involve the theatricalisation of protest demonstrations, peasants' marches, secular processions, parades, meetings of workers or other organised groups, street commissions, etc., using all available theatrical elements, such as masks, songs, dances, choreography, etc. Finally [...] Legislative Theatre is a set of processes which mixes Forum Theatre and the conventional rituals of a parliamentary chamber or assembly, with the objective of arriving at the formulation of coherent and viable bills of law (pp. 6).

Cada una de estas técnicas, como hemos mencionado, tiene por objeto transformar al espectador en espect-actor, es decir, en protagonista de la acción dramática que discierna y proponga acciones reales que le conduzcan a la propia liberación, para ser en palabras de Adam Smith un "espectador juicioso".

- El Teatro imagen: mediante imágenes se hace uso de la capacidad de dibujar ideas en una forma concreta dada la ausencia de las palabras. Icónico, primero, y posteriormente oral, el protagonismodellenguajesehaceevidentecuandosetoma concienciaqueanteunamismaimagen no descubrimos todos lo mismo. La interpretación depende de la subjetividad de cada quien.

- El Teatro periodístico: permite transformar noticias diarias o cualquier pieza no dramática a 
la escena teatral. Existen varios métodos para llevar a cabo esta técnica y para causar distintos efectos dentro del público. Lectura simple: un artículo de noticia leído fuera de contexto del periódico (el cual lo hace falso o controversial); lectura cruzada: dos artículos de noticias son leídos en forma alterna complementando o contrastándose el uno al otro en una nueva dimensión; lectura complementaria: información general omitida por la fuente de la noticia es añadida por el público, lectura rítmica: la noticia es leída con ritmo (musical), así esto actúa como filtro para la noticia, dando a conocer el verdadero contenido que estaba inicialmente oculto en el periódico; acción paralela: los actores hacen mímica de las acciones mientras el periódico es leído. El público escucha la noticia mientras observa la mímica; improvisación: las noticias son improvisadas en el escenario, para explotar así todas sus variantes y posibilidades, histórico: información de momentos históricos, sucesos en otros países o en sistemas sociales son añadidos a la noticia; refuerzo: el artículo es leído acompañado de canciones o de imágenes, para ayudar a la noticia a ser percibida de una manera o de otra; concreción de los abstracto: el contenido abstracto en las noticias es llevado a lo concreto en el escenario ej. Hambre, desempleo y texto fuera de contexto: una noticia es presentada fuera del contexto en el que originalmente fue publicado.

- Arco iris del deseo: este tipo de teatro busca ahondar problemas psicológicos y crear personajes en una obra. Permite analizar el color de nuestros deseos, apetencias, sensaciones, emociones y voluntades para armonizarlos en otros lienzos más acordes con nuestra felicidad. El amor y el odio, la tristeza y la euforia, el miedo y el valor, todo se mezcla y se confunde en proporciones diferentes.

- Teatro foro: promueve la creación colectiva ya que el grupo que concibe la obra son los oprimidos mismos. En el Teatro foro, en particular, una vez representada la obra, los espectadores pueden participar convirtiéndose en actores y actrices. Esta técnica en la más difundida; un espectáculo basado en hechos reales en los cuales los personajes oprimidos y opresores entran en conflicto de forma clara y objetiva, en la defensa de sus deseos e intereses. En esta confrontación, el oprimido fracasa y el público es invitado para entrar en escena de manera voluntaria, es decir, cuando está emocionalmente conectado con la situación opresora. Al entrar a la escena, propone alternativas de solución.

- El Teatro invisible: Son obras previamente ensayadas que son interpretadas en lugares públicos sin previo aviso, la intención del acto es provocar debate, que las personas tomen una posición ante el problema, que politicen a la vida cotidiana y que lo traten de solucionar. De esta forma los espectadores pasivos, se trasforman en espect-actores sin darse cuenta.

- Acciones directas: se pretende envolver teatralmente las manifestaciones de protesta como las marchas estudiantiles, de campesinos, de obreros, de trabajadores, procesiones religiosas o simplemente reuniones. Para ello se pueden utilizar máscaras, coreografías, danzas, canciones, etc.

- Teatro legislativo: incentiva a lanzar propuestas legislativas sin un legislador, pero con el apoyo de los Forum populares participativos Llamado "Foro" porque brinda la posibilidad de usar el debate dentro de la obra. 
Figura 3. The Tree of the Theatre of the Oppressed' by Augusto Boal

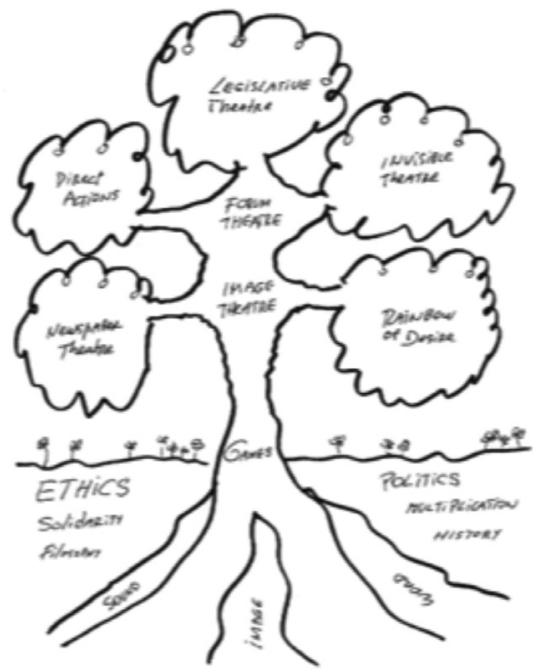

Fuente: Augusto Boal

Las raíces del árbol permiten que las técnicas se alimenten de la solidaridad, la filosofía, la ética, el sonido, las imágenes, las palabras, la política, la multiplicación de situaciones, las emociones y la historia como los elementos que buscan una mejor comprensión del hombre $\mathrm{y}$ de la sociedad en que vive. El tronco representa los juegos (y ejercicios de roles), sobre los cuales descansa todo el trabajo del Teatro del oprimido. En las copas del árbol se encuentran las técnicas que sirven como medio para expulsar, compartir y solucionar situaciones opresoras.

Lejos de ser propio de dramaturgos, el teatro del oprimido (nos interesa especialmente el teatro foro) puede ser desarrollado por cualquier persona en situación de opresión, máxime cuando en la actualidad la educación profesionalizante, bancaria y repetitiva (Freire) la sociedad líquida (Bauman, 2002) e hiperconsumista (Lipovetsky, 2007) y el protagonismo de la razón en detrimento de la emoción, nos hace menos felices y aumenta el desfase con los requerimientos actuales.

Sin una academia que favorezca la conexión emoción-razón, los estudiantes quedan atrapados en el mecanicismo y estancamiento curricular. Adoptar otras estrategias metodológicas que conecten la emoción con la razón de frente a los requerimientos sociales y educativos de la actualidad, resulta perentorio. El teatro, el cine y la literatura, serían un buen ejemplo de ello.

Además de Augusto Boal, autores como Martha Nussbaum resultan ser un buen apoyo pedagógico del uso de estas nuevas exploraciones metodológicas en el ámbito educativo.

De la misma forma que lo hizo Paulo Freire, Boal aportó a la liberación social a través del 
teatro en todas sus versiones. El Teatro del oprimido democratiza mediante un sistema de técnicas e improvisación teatral, una modalidad de trabajo socio-comunitaria que tuviera el lenguaje teatral como herramienta catalizadora. Boal construyó una concepción de la sociedad como conflicto, y en ella, los problemas sociales actuales son vistos como producto de las relaciones sociales asimétricas que dejan al Teatro del oprimido al servicio de las personas más vulnerables. ¿Es este un acto de exclusión social?

\subsubsection{Martha Nussbaum: Justicia poética}

La pensadora norteamericana sostiene la eficacia de la literatura como herramienta para humanizar y educar en una ciudadanía democrática y acercarse a las vidas individuales de los sujetos. La literatura cumple con un rol de apertura que es invalorable y genera emociones que es capaz de suscitar y modificar debido a su carácter racional, emocional y cognitivo. En síntesis, en Justicia poética, subyace una pedagogía de emocional que pretende reivindicar el papel de las emociones en la toma de decisiones "racionales" y su contribución a la racionalidad pública. Leemos en Justicia poética:

El intelecto sin emociones es, por así decirlo, ciego para los valores: no capta el valor de la muestra de una persona, una captación que es inherente al juicio basado en las emociones [...] la represión de la emoción [...], en cambio, puede lograr que las emociones retornen de manera más destructiva, genuinamente irracional (Nussbaum, 1997, pp. 102 - 104).

Es evidente que para Nussbaum las emociones tienen fines vinculados con la eudaimonía, que serían la clave para la felicidad interior (única felicidad relativamente sostenible) y la cohesión social que brilla por su ausencia en nuestros días. Si cohibir las emociones puede llegar a connotaciones genuinamente negativas, se hace necesario incluirlas en la educación en lugar de intentar reprimirlas. La estandarización de la educación, los currículos y los programas universitarios, serían claros indicadores de la actualidad Pansófica heredada de Comenio a través de Didáctica Magna.

Nussbaum, consciente de esta situación educativa y social hace énfasis en la posibilidad de una significación moral y psicológica de las emociones a través del arte, particularmente de la literatura, en la cual la conexión entre la forma y el contenido hace posible la expresión de un mensaje complejo, que es innegablemente cognitivo y lingüístico, en la que lo connotativo, cuando no lo perlocucionario se superpone a lo denotativo sin necesidad de una definición estricta de los conceptos que utiliza; ejemplos de esto son las metáforas y otras figuras literarias que pueblan la literatura y que vienen cargadas no necesariamente de conceptos, sino de segundos sentidos y provocaciones que generan emociones.

Si los niños y adolescentes son consumidores intensivos de cultura extraescolar, ¿cuál es el grado de adecuación de la oferta educativa a las condiciones de vida, expectativas de las nuevas generaciones y a las demandas de las diferentes esferas sociales? Atender al mencionado interrogante resulta perentorio. Si el teatro, la literatura y el cine favorecen el aprendizaje 
de contenidos y la cohesión social, adoptar prácticas pedagógicas ricas en interacciones y conexión emoción-razón, resultan determinantes en una sociedad en la que de un lado, el factor emocional reclama protagonismo, y del otro lado, los avances neurofisiológicos señalan otras estructuras cerebrales implicadas en la emoción, la motivación y la prolongación de la memoria.

\subsection{Neurofisiología de la conexión emoción-razón}

Resulta perentorio que los últimos descubrimientos desarrollados desde la neuropsicología operen un cambio en la concepción del cerebro. Por lo menos a partir del siglo XIX, se empieza a evidenciar la presencia de otros sistemas cerebrales además del racional que ha gozado, durante siglos, de protagonismo gratuito. No solo el cerebro racional decidiría nuestras respuestas y acciones, sino, especialmente el emocional. Desde entonces, se hace evidente que para comprender el mundo y surfear (Bauman), el cerebro emocional resulta determinante, para no terminar ahogándonos en la multiplicidad de opciones y oportunidades, en consecuencia, la emoción debe ganar en protagonismo en el proceso educativo.

Son muchas las emociones que podemos experimentar los seres humanos, algunas han sido llamadas 'emociones 'primarias', como el miedo, la ira, la alegría, la tristeza, el disgusto y la sorpresa. Estas emociones van acompañadas de patrones de conducta: respuestas faciales, motoras y endocrinas que han sido estereotipadas. La envidia, la vergüenza, la culpa, la calma y la depresión son llamadas 'emociones secundarias', por contener un componente cognitivo más alto que las primarias.

La alteración de los sistemas neurales de los que dependen las expresiones emocionales, provoca grandes trastornos de conducta. La mayoría de las enfermedades siquiátricas son, sobre todo, alteraciones en el modo de experimentar las emociones. Considerados como procesos independientes y en cierta medida contrapuestos, la cognición (razón) y emoción trabajan juntos, toda vez que la emoción abarca desde la experiencia subjetiva (el sentimiento) hasta las reacciones llamadas vegetativas (sudoración, temblor, palidez) y motoras (gestos, posturas..).

Muchos han sido los autores que se han preocupado por aportar a la comprensión de la relación (casi siempre antagónica) emoción-razón. Inicialmente la psicología contemporánea y luego la neurobiología, han puesto en cuestión el prejuicio de la tradición filosófica que va de Platón al positivismo y que atribuye un protagonismo superlativo a la razón en detrimento de la emoción. Originada en la perspectiva filosófica de Hume y en las observaciones de Darwin, la emoción se encarga de la motivación, la fuerza y la priorización de las acciones, mientras que la razón prevee, abstrae e infiere.

En La expresión de las emociones en el hombre y los animales publicada en 1872, Darwin estableció la finalidad funcional de la emoción: para la supervivencia (cerebro reptil) a través del miedo que finaliza con el escape o la procreación por medio del amor y la lujuria. Para comprender un poco más la neurofisiología de la emoción, presentaremos dos posiciones 
frente a la evolución cerebral desde sus inicios hasta desplegar el sistema o cerebro límbico, es decir, el de las emociones: la propuesta por John Morgan en El cerebro en evolución y la de Steve Mithen en Arqueología de la mente.

Con Morgan (1999) sabemos que las medusas son los organismos más simples que tienen sistema nervioso. En virtud de la comunicación entre sus neuronas este sistema evoluciona dando paso al cerebro de los animales complejos. El desarrollo del mecanismo neuronal básico preparó las condiciones para la gran proliferación de la vida animal que se produjo en el periodo cámbrico (hace más de quinientos millones de años). Los cordados tempranos de este periodo fueron animales con cerebros muy sencillos que al evolucionar se convirtieron en los primeros vertebrados (peces con espina dorsal). Algunos de estos originarios peces desarrollaron un método para aislar sus axones al envolverlos en una materia grasa denominada mielina, que facilitó la evolución de los cerebros de mayor tamaño. Algunos de los descendientes de los peces se arrastraron por las orillas cenagosas y se posaron en tierra seca. Puestos a prueba por los bruscos cambios de temperatura y la alerta máxima para la supervivencia, algunos trasformaron su sangre fría en sangre caliente. Los que tuvieron más éxito en este cambio, se convirtieron en los antepasados de aves y mamíferos. Finalmente, surgieron los animales cuyo cerebro más grande se enfrenta a la necesidad de compartir la energía disponible con otros órganos del cuerpo por lo que precisan de más tiempo para madurar, y en consecuencia, las crías requieren de cuidado más prolongado. Leemos en Evolving brains:

The development of this basic neuronal mechanism set the stage for the great proliferation of animal life that occurred during the Cambrian period, more than half a billion years ago. Among the less spectacular of these Cambrian animals were the [...] From this modest beginning evolved the earliest vertebrates [...]. Some of their descendants [...] crawled up on the muddy shores and eventually took up permanent residence on dry land. Challenged by the severe temperature with becoming warmblooded, and the most successful became the ancestors of birds and mammals. The brain must compete with other organs in the body for the limited amount of energy available, which is a powerful constraint on the evolution of large brains. Large brains also require a long time to mature, which greatly reduces the rate at which their possessors can reproduce. Because large-brained infants are slow to develop and are dependent on their parents for such a long time, the parents must invest a great deal of effort in raising their infants. The evolution of very large brains requires sustained care for very dependent and slowly developing offspring (Morgan, 1999, pp. 12-13).

La evolución de los cerebros grandes (incluyendo el cerebro emocional) en los seres humanos dependió especialmente del cambio de temperatura sanguínea, del establecimiento de la familia ampliada y del tiempo de acompañamiento de las crías (lo que fortaleció las relaciones afectivas (emociones) de acuerdo con Morgan.

Con la metáfora "una obra dramática dividida en cuatro actos", Mithen permite rastrear los estadios evolutivos de la mente incluyendo la afectividad. Leemos en Arqueología de la mente. 
Orígenes del arte, de la religión y de la ciencia:

Nuestro punto de partida de la prehistoria de la mente debe remontarse a no menos de 6 millones de años, porque fue entonces cuando vivió un antropomorfo cuyos descendientes evolucionaron en dos direcciones divergentes, [...] hacia los antropomorfos modernos, los chimpancés y los gorilas y la otra hacia los humanos modernos [...] seis millones de años es un periodo larguísimo de tiempo para empezar a aprehender sus verdaderas dimensiones y vislumbrar su patrón de acontecimientos más importante, propongo pensar en el como si de una obra dramática se tratara, el drama de nuestro pasado [...] he dividido el drama en cuatro actos (Mithen, 1996, pp. $22-23)$.

Cada uno de estos cuatro actos tiene sus propios actores, tiempo en que se desenvuelven los hechos y escenas vividas.

Acto 1. Inicia en algún lugar del África hace 6 millones de años y tiene como único actor el antropomorfo ancestral. Actor conocido con el nombre de ancestro en común y/o eslabón perdido, esto debido a la falta de información acerca de aquel antropomorfo.

Acto 2. Tiene lugar entre 4.5 y 1.8 millones de años. Empieza con la aparición de Autralopithecus ramidus es el primero de los llamados australopitecinus. 300.000 años después aparece un segundo actor Australopithecus Anamensis. Los dos actores viven en medios arbóreos y son vegetarianos. Hace 3.5 millones de años abandonaron el escenario y fueron sustituidos por Australopithecus Aferensis. Representado por la famosa Lucy, este primate anduvo erguido sobre ambas piernas y trepó los árboles con gran facilidad. Sus descendientes son conocidos como Australopithecus Africanus. Mithen identifica en estos primates una especie de "Inteligencia social", que les permitía identificar los amigos o enemigos e inferir sus estados mentales. Igualmente mostraron gran habilidad para resolver con mayor eficacia problemas del mundo social, más que para resolver problemas del mundo no social, es decir, lógicos, lo que haría evidente la presencia de los sistemas o cerebros reptil y límbico y ausencia parcial del neocortex.

Acto 3. La primera escena de dos que contiene este acto, aparece hace 1.8 millones de años (100.000 años). Los primeros miembros del linaje Homo con un cerebro 1.5 veces más grande que el de sus primos los australopitecinos y con una considerable variedad de tamaño y forma. Conocido como Homo habilis, es portador de útiles y artefactos de piedra que le posibilitan implementar métodos de caza más efectivos y la ingesta de carne en su dieta. La segunda escena de este acto empieza con el Pleistoceno, época en la que empiezan a formarse las primeras capas de hielo y con ellas, aparece en escena el Homo erectus. De acuerdo con Mithen lo más llamativo es que su llegada se hace de forma simultánea en tres partes del mundo; en el este de África, en China y en Java (indonesia).

Acto 4. Caracterizado por tres escenas. La primera inicia 100.000 años atrás hasta la actualidad. Entra en escena nuestra propia especie el Homo sapiens sapiens, que es visto por primera vez en 
el sur de África y en el próximo oriente. Estos homo, perfeccionan los instrumentos de caza, entierran a sus muertos y utilizan ajuares funerarios. La segunda escena surge hace 60.000 años cuando en el sureste asiático el Homo sapiens sapiens construye barcas para luego ejecutar la primera travesía a Australia, lo que evidencia la presencia, no solo del cerebro reptil y límbico, sino, además, del neocortex. Al respecto Mithen sostiene que en la expansión que presentó el cerebro en los primeros miembros del linaje Homo, ocurrió un aumento desproporcionado de un área del cerebro conocida como el córtex prefrontal, dicho aumento habría provocado una reorganización de las conexiones en el interior del cerebro, favoreciendo el desarrollo de una capacidad lingüística, a lo que llama "Proceso Inteligencia Lingüística". Finalmente surge en este cuarto acto una tercera escena, aparece en el Próximo Oriente gente sembrando cosechas y domesticando animales. Así, cada vez todo transcurre con mayor velocidad, los actores ahora construyen grandes emporios y alucinantes artefactos como automóviles y ordenadores.

En síntesis, el cambio de hábitat (del agua a la selva), de sangre (de fría a caliente) y el crecimiento del cerebro que lo obligó a disputar la energía con otros órganos del cuerpo prolongando la maduración y el cuidado de las crías, de acuerdo con Morgan, desarrollaron el cerebro límbico. Con respecto a Mithen podría decirse que la aparición o desarrollo del cerebro límbico tuvo lugar en el acto 2, toda vez que el antropomorfo ancestral o eslabón perdido, vivió en medios arbóreos (que requiere más que cerebro reptil), al igual que el Australopithecus Aferensis (la famosa Lucy) que anduvo erguido sobre ambas piernas y desarrolló la "Inteligencia social".

La evolución del cerebro de pez a reptil, de reptil a mamífero y de mamífero a humano, es bien conocida por algunos pensadores contemporáneos que se han descubierto la importancia de las emociones. Victoria Camps, es un ejemplo de ellos. En la introducción de su libro titulado El gobierno de las emociones, es posible inferir el protagonismo asignado a la conexión emoción-razón.

[...] No hay razón práctica sin sentimientos. Nadie que no sea ajeno a la psicología o a las neurociencias discute ya esta tesis. Todas las ciencias sociales parten hoy del supuesto, exagerándolo a veces, de que somos seres emotivos y no solo racionales (Camps, 2011).

Lejos de ser excluyentes, la emoción y la razón mantienen relación de cooperación que la academia separa. Que las recientes investigaciones reconozcan las bases biológicas y el protagonismo de la emoción y su relación con la razón, nos alienta a compartir en este capítulo avances que así lo evidencian. MacLean y Damasio, por ejemplo, se dan cuenta que el cerebro humano no es solo uno, ni dos, sino, tres, desvirtuando la teorías bipartidistas como la de cuerpo-alma o neocortex-cerebelo. LeDoux y Carretié sostienen la autonomía de emoción frente a la razón, lo que Platón por supuesto no compartiría. Maturana sostiene la presencia del amor como emoción central del ser humano desde hace por lo menos cinco o seis millones de años. Con el amor se legitima al otro o se agrede (indiferencia). El poder de la emoción al tomar decisiones diarias que creemos solamente "racionales", es un hallazgo que comparte MacLean y LeDoux. La pluralidad humana defendida por Maturana, es el punto de encuentro con Gardner, quien a través de su teoría sobre las 
inteligencias múltiples, actualiza la idea de inteligencia de cara a las trasformaciones sociales y diversidad humana, dejando en entredicho estereotipos de inteligencia que de un lado, brindan el primerísimo lugar a la lógica y a la lingüística y del otro lado, sostienen la eficacia del Método con mayúscula, como el propuesto por Comenio en la Didáctica Magna.

\subsubsection{Paul MacLean. Fisiología de la conexón emoción-razón. Cerebro trino}

Las recientes investigaciones reconocen no solo las bases biológicas de las emociones y su relación con la razón y la conducta humana, sino, que además, destacan como nunca antes, el protagonismo de la emoción. El cerebro triuno del físico y neurocientífico norteamericano Paul MacLean, marcaría un hito en los aportes al campo sicológico (retomando la propuesta de Papez). Tres estructuras, sistemas cerebrales o capas que fueron surgiendo uno tras otro respondiendo a las necesidades evolutivas. Cada capa según MacLean, está orientada hacia funciones separadas del cerebro, pero las tres interactúan sustancialmente.

Figura 4. Cerebro triuno (trino) de Paul MacLean
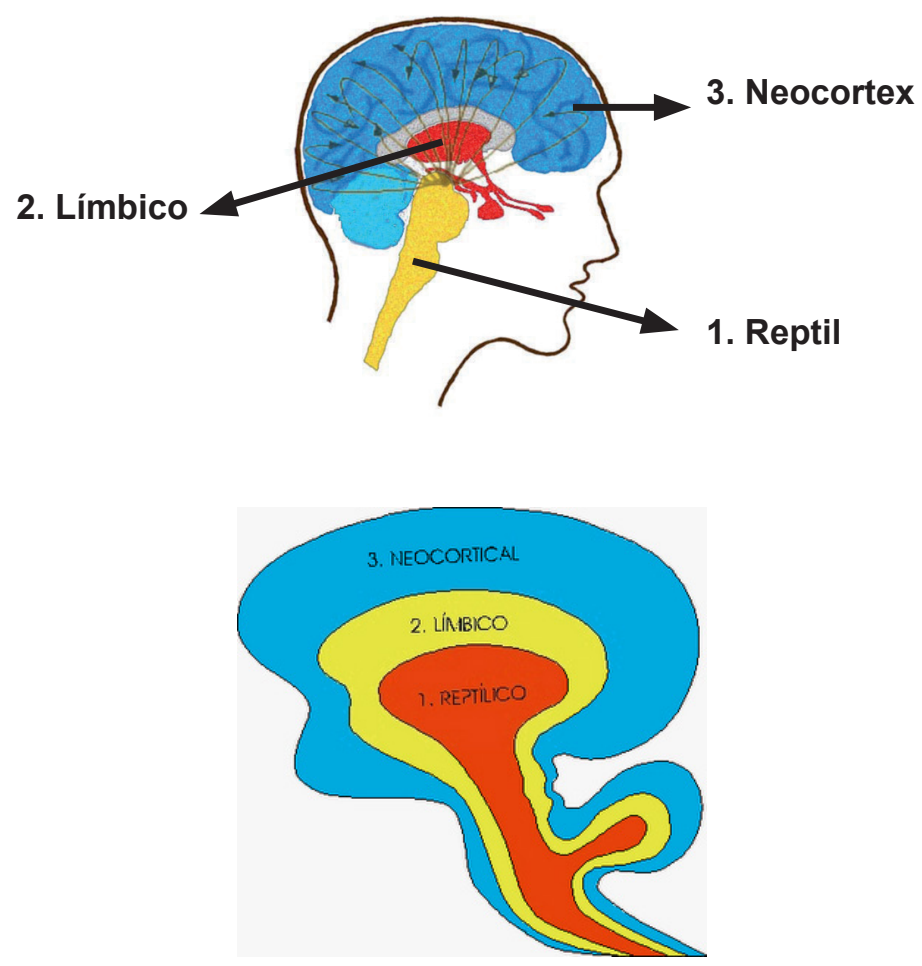

Fuente: Paul MacLean 
1. El reptil o básico, sería el primero en surgir (hace por lo menos 500 millones de años) y el último en desaparecer al morir. Siendo el más antiguo, es movido por el instinto y controla no solo nuestra más primitiva técnica de supervivencia, huir o luchar (emociones propias de este cerebro), sino, además, las conductas instintivas y emociones primarias como el hambre, deseos sexuales y la temperatura corporal. La repetición, la imitación, la inhibición y el engaño son actividades básicas que nos brindan estabilidad y seguridad. Este cerebro se ubicaría especialmente en la columna y el tallo vertebral. Todas las experiencias y conductas que siendo niños nos permitieron sobrevivir, quedan rápidamente grabadas en este cerebro, de ahí que se detonen automáticamente o inconscientemente de acuerdo al estímulo exterior. En necesario recordar que aunque se ubique en una área específica, no solo se encuentra interconectado con los demás cerebros, sino que, además, comparten información si nos atenemos a MacLean en The brain in relation to empathy and medical education:

[...] Man has inherited the basic structure and organization of 3 brains, [...] 2 of which are quite similar to those of animals their great disparity in structure and chemistry, all 3 must function together. Man's brain of oldest heritage is basically reptilian. It forms the matrix of the brain stem and comprises much of the so-called reticular system, midbrain, and basal ganglia. Superimposed on the reptilian is a structure inherited from lower mammals. It consists of the 2 oldest forms of cerebral cortex together with related nuclei of the brain stem (MacLean, 1967, pp. 375).

2. El sistema límbico (paleomamífero), es el segundo en aparecer, precediendo al neocortex, es la parte cerebral responsable de las emociones, el deseo, el sentir, los afectos, los valores, las creencias y la memoria a largo plazo, aporte trascendental para la academia. El miedo y la ira son las dos emociones básicas de este sistema. De acuerdo con MacLean, el sistema o cerebro límbico es el puente que comunica las conductas básicas, irracionales y más internas (cerebro reptil), con la razón (neocortex). El sistema límbico sería la clave para entender, de un lado, el comportamiento humano, y del otro lado, las formas de razonar y sentir, por lo que debe ganar protagonismo en la academia. Continuamos con The Triune Brain in Evolution: Role in Paleocerebral Functions

As it is common to the brains of all mammals, 1 might refer to it as the paleomammalian brain (limbic brain or system]. (...) the structures of the limbic system arose early in mammalian evolution (hence "paleomammalian") and were responsible for the motivation and emotion involved in feeding, reproductive behavior, and parental behavior (pp. 375).

3. El neocortex, ubicado en la parte externa del cerebro, (envolviendo el sistema límbico y posteriormente el reptil) es el área de la actividad cognitiva, en él se gesta el lenguaje, el pensamiento lógico y formal, la información sensorial y los movimientos voluntarios. Este cerebro o sistema lo poseen los mamíferos más complejos, específicamente el ser humano. Goza de popularidad en la academia aunque no sea el más importante. 
Superimposed on the old mammalian brain and appearing late in evolution is a more elaborate form of cortex called neocortex which, together with its associated nuclei of the brain stem, reaches the most advanced stage of development in man and overshadows the rest of the brain. It can be characterized as neomammalian in structure and organization (pp. 375).

Cada capa del cerebro no solo es distinta en su estructura física, sino, además, química pero gracias a la extraordinaria red de conexiones se interrelacionan y complementan en las acciones ejecutadas y en la toma de decisiones, dando piso teórico a la inclusión de lo emocional en lo racional, como bien podría ocurrir en el plano educativo.

Figura 5. Estructura del sistema límbico (MacLean)

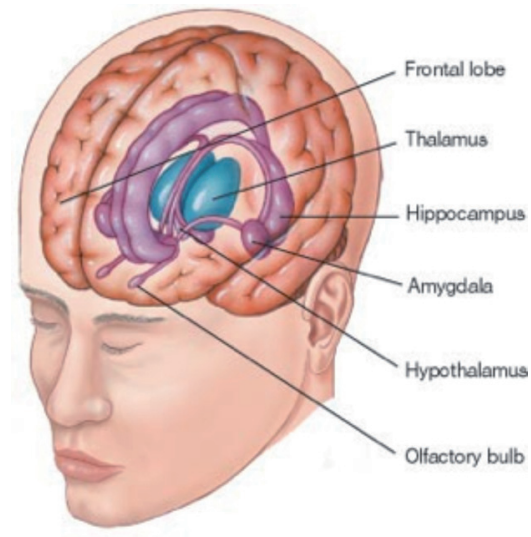

Fuente: Paul MacLean

Lóbulo frontal: es llamado el "centro ejecutivo del cerebro". Los lóbulos frontales son las estructuras cerebrales encargadas de la planeación, regulación y control de los procesos psicológicos y de las diversas opciones de conducta humana que a su vez dependen de las motivaciones e intereses. Su daño o afectación altera desde la regulación de las emociones, la conducta social, el pensamiento abstracto y la metacognición hasta el comportamiento.

Que el sistema límbico cuente con sus propias estructuras fisiológicas, haría repensar el protagonismo de lo emocional en el proceso educativo. Otros escritos de MacLean como Psychosomatic disease and the 'visceral brain': recent developments bearing on the Papez theory of emotion, proporcionan suficientes evidencias al respecto: "our affective behavior continues to be dominated by a relatively crude and primitive system. This situation provides a clue to understanding the difference between what we 'feel' and what we 'know'" (pp. 351).

El racionalismo hizo de la emoción, la pasión, el sentimiento, fenómenos de segunda categoría en la conducta humana. Cuando la neurociencia construye el concepto de sistema límbico, 
recupera su legitimidad perdida. A los conceptos ya instituidos de cerebro racional (neocortex) y cerebro instintivo (cerebelo y tallo cerebral), se adiciona el de cerebro emocional. Tres cerebros en uno es la fórmula de MacLean con el nombre de "cerebro triuno". A pesar de todo lo que se puede decir a su favor, en cuanto relativiza el racionalismo, la idea de un cerebro funcionando en tres partes nos hace olvidar por momentos que el cerebro es uno solo y que las más de las veces, las tres partes interactúan como un todo, de manera que los tres cerebros constituyen una idealización de la teoría que no por pertinente deja de resultar excesiva.

Que en el cerebro se origine el pensamiento consciente y las emociones, haría que nos ocupemos de otra educación de frente a los avances en materia de neurociencia y de los requerimientos educativos y sociales de la actualidad, como también lo propone Antonio Damasio.

\subsubsection{Antonio Damasio}

La historia de Occidente contiene una larga lista de autores que han pretendido explicar el todo por una de sus partes. Marx con la economía y Freud con el sexo, son algunos de los más célebres, Heidegger lo ha hecho con lenguaje Repaille con la publicidad, y en ese orden de ideas, es posible pensar que la neurociencia no sea ajena a semejante tentación. Al reivindicar el papel de la emoción (caso de Phineas Gage) y todavía más el de la intuición (la tripa), Damasio aporta una visión del ser humano más realista y ajustada a los hechos de aquella que ha colonizado el imaginario colectivo a través de los siglos. Que semejantes aportes se fundamenten en la neurociencia no debe llevarnos a perder la pista que el hombre es también producto del azar (una serie de catástrofes naturales que nos han llevado a ser lo que somos) y el capricho cuando elegimos la opción más débil. Que en el mundo contemporáneo no siempre prioricemos la supervivencia, ni la adaptación al medio, ni la coordinación de acciones con los demás, continua el profesor Serna, sería una prueba de lo que queremos expresar.

Según los hallazgos de sus investigaciones, únicamente nos motiva lo que nos emociona, en otras palabras, de la emoción depende la motivación y sin motivación no hay memoria. Leemos en En busca de Spinoza:

Nuestro aprendizaje asociativo conecta emociones con pensamientos "en una rica red de dos direcciones". Determinados pensamientos evocan determinadas emociones, y viceversa. Los niveles cognitivos y emocionales de procesamiento están continuamente conectados de esta manera (Damasio, 2005, pp. 72).

Aunque la distinción sentimiento-emoción es difusa porque no sabemos dónde empieza un sentimiento y dónde empieza una emoción, este es un modelo que Damasio elaboró para ayudar a la comprensión del tema en el que no solo la memoria depende de la emoción, sino, además la motivación, al respecto nos dice: "emotions play an important role in people's lives since they influence relevant psychological processes such as attention, memory, and motivation (pp. 34).

Poner "empeño" y "corazón", son expresiones por medio de las cuales se alude a una serie de 
emociones de las que quizá no sabemos mucho, pero no tenemos duda que influyen en lo que sentimos, lo que aprendemos, lo que hacemos, y lo que da sentido a nuestras vidas. Si la emoción facilita alcanzar las metas propuestas, entonces esta emoción funciona como metaemoción (Mayer y Stevens), que puede ser manipulada racionalmente.

Así como la razón depende de la emoción, la emoción puede ser encausada por la razón. Leemos en En busca de Spinoza:

Estas reacciones automáticas crean condiciones en el organismo humano que, una vez cartografiadas en el sistema nervioso, pueden representarse como placenteras o dolorosas [...] conscientes de la relación entre determinados objetivos y determinadas emociones, podemos esforzarnos intencionadamente por controlar nuestras emociones, al menos en cierta medida. [...] Al controlar nuestra interacción con los objetos que causan emociones ejercemos, efectivamente, un cierto control sobre los procesos vitales y llevamos al organismo a una armonía mayor o menor [...]. En realidad estamos anulando el automatismo y la inconsciencia tiránicos de la maquinaria emocional (pp. 54).

Si el aprendizaje es un proceso, es menester de asumir constructos educativos que atribuyan sentido y significado en la relaciones con el entorno, en otras palabras, que conecten la construcción de significados (lo racional) con la atribución de sentidos (lo emocional).

Los hallazgos de la neurociencia trascienden lo individual y permean lo social abriendo paso el estudio de las emociones sociales, con las cuales se avanzaría en la compresión y posterior solución del actual conflicto producido según él por los deseos inducidos por el cerebro reptil. En las emociones intensas y positivas estaría la clave para superar el conflicto en cuestión, sostiene Damasio, en la entrevista hecha por Eduard Punset:

[...] Hay dos posturas sobre cómo se puede contener la pasión. La primera es la que puede asociarse con Kant, en la que, literalmente, dices que no, y por pura voluntad lo niegas; y luego está una postura que podríamos asociar con gente como Spinoza, o como David Hume, mucho más humanizada, porque se percatan de que la mejor manera de contrarrestar una emoción negativa concreta es tener una emoción positiva muy fuerte (http://www.eduardpunset.es).

La utilización de la emoción positiva contra la emoción negativa, es también un tema educativo. En la medida en que aumenten las emociones positivas en la academia, las emociones negativas provenientes del consumo desenfrenado (Lipovetsky, 2007) que nos deja a merced de la mercadotecnia perderán vigencia.

[... Es la idea que tenía Spinoza de que, para contrarrestar una emoción negativa, hay que tener una emoción positiva todavía más fuerte que la neutralice [...] hay emociones buenas y emociones malas. Y, de hecho, podríamos decir que el objetivo de una buena educación [...] es organizar nuestras emociones de tal modo que podamos 
cultivar las mejores emociones y eliminar las peores, porque como seres humanos tenemos ambos tipos [...] el propósito de una buena educación y el papel de una sociedad próspera es permitir que se cultive lo mejor [...] las diferentes moléculas tienen consecuencias distintas. Lo único igual es que todas ellas son emociones, siempre se acaba en un estado emocional, pero no tiene que ser exactamente el mismo estado (http://www.eduardpunset.es).

Si las emociones fuertes (cerebro límbico) permiten a las personas dominar los deseos (cerebro reptil) a través de la razón (cerebro racional o neocortex), es menester educar en consecuencia. Una vez más la educación representa, sino la única, la mejor opción. Que la subjetividad humana procure la cohesión social y la construcción de una sociedad más justa, pacífica y feliz, no solo serían apuestas de Damasio, sino, además, el reto de todo proceso educativo. Leemos en Y el cerebro creó al hombre:

[...] Cuando falta la conciencia, el punto de vista personal queda suspendido, privado de sus funciones; sin conciencia no hay conocimiento de nuestra existencia, tampoco conocimiento de que exista algo más. Si la conciencia no se hubiera desarrollo en el decurso de la evolución y no se hubiese expandido hasta alcanzar su versión humana, la humanidad tal como ahora la conocemos en toda su fragilidad y vigor, tampoco habría evolucionado (Damasio, 2010, p. 21).

Steven Mithen en Arqueología de la mente, confirma la mencionada evolución registrada por Damasio:

Podemos afirmar sin temor a error que [...] humanos primitivos pudieron perfectamente poseer inteligencia social compleja desde el momento en que se ha detectado su existencia entre los primates no humanos [...]. La evidencia más reveladora es el tamaño del cerebro de los humanos primitivos [...]. Tenemos buenas razones para pensar que los humanos primitivos, especialmente los que vivieron a partir de hace 200.000 años, fueron socialmente tan inteligentes como los humanos modernos (Mithen, 1998, pp. 143).

Si los últimos avances antropológicos y arqueológicos de los investigadores que se ocupan de la mente demuestran su evolución hasta convertirse en un ser social, si estar emocionalmente perturbados nos lleva a decir que "no podemos pensar bien" y permite explicar por qué la tensión emocional prolongada puede obstaculizar las facultades intelectuales, entonces nuestro funcionamiento vital estaría cohabitado por dos tipos de inteligencia: racional y emocional.

Si solo nos motiva lo que nos emociona, si recordamos con más facilidad lo que nos motiva, resulta determinante dictar clases que motiven y contenidos que conecten con la emoción.

Antonio Damasio, en El error de Descartes, insiste en la importancia de la emoción. A partir del análisis de casos como el de Phineas Gage, un trabajador destacado, que después de sufrir un accidente en el que resultó lesionado su lóbulo prefrontal (parte del cerebro límbico), quedó inhabilitado para tomar decisiones con la participación de la emoción. Con el neocortex 
intacto, pero inhabilitado el lóbulo prefrontal, Gage, no logró sostener su vida familiar y social, lo que conllevó al retiro de la empresa y a la creciente dificultad para vincularse nuevamente a la vida laboral. Este caso verifica la hipótesis según la cual las capacidades intelectuales resultan insuficientes para sacar adelante los propósitos de la vida cotidiana, cuando, además, lo que hoy día se conoce como inteligencia emocional sería vital. La emoción, el sentimiento y la regulación bilógica desempeñan su papel en la razón humana, de acuerdo con Damasio:

La razón parece depender de sistemas cerebrales específicos, algunos de los cuales resultan procesar sentimientos. De manera que puede haber una pista de conexión, en términos anatómicos y funcionales, desde la razón a los sentimientos y al cuerpo (Damasio, 2003, pp. 226).

Contario a lo que se cree que la reducción del componente emocional, nos hace seres irracionales y débiles como lo advirtió Platón, su vigencia aporta lucidez y contextualiza nuestras decisiones:

La reducción de las emociones puede constituir una causa igualmente importante de comportamiento irracional. La conexión contra intuitiva entre la ausencia de emoción y comportamiento descarriado, puede decirnos algo sobre la maquinaria biología de la razón. [...] Los poderes de la razón y la experiencia de la emoción se deterioran juntos (pp. 62).

Que la emoción y la razón funcionen de manera articulada, es evidente a partir de los trabajos de MacLean y Damasio; no obstante, la razón sin la emoción es una vieja pretensión de los filósofos y la emoción sin la razón un reciente descubrimiento de LeDoux y Carretié.

\subsubsection{Joseph LeDoux}

Joseph LeDoux se ha preocupado por avanzar en la neurofisiología de la emoción. Profundiza las formas como el cerebro humano detecta y responde emocionalmente a los estímulos no solo internos, sino, además, externos. Que las decisiones racionales estén poderosamente influenciadas por las emociones, obedecería a que de la amígdala parten muchas más vías de comunicación hacia la corteza o cerebro cognitivo que en dirección contraria. Leemos en The emotional brain.

I have tried to present a strong case for the argument that much emotional processing occurs unconsciously and therefore that there is more to an emotion. But the same argument was made about cognition [...] - that not all aspects of thinking, reasoning, solving problems, and intelligence can be understood on basis of introspection. Given that emotional and cognitive processing both largely occur unconsciously, it is possible that emotional and cognitive processing are the same, or, as it is usually said, that emotion is just a kind of cognition. The emotional brain [...] thinking, reasoning and intelligence, it also includes emotion. [...] cognition and emotion are given equal billing in a field that studies both (LeDoux, 1996, pp. 68). 
Lejos de pretender reprimir la emoción como lo procuraba el primer Kant o los filósofos racionalistas, sino de brindar espacios y acciones que permitan la emulación de los estudiantes de emociones adecuadas de faciliten la óptima contextualización de las actividades racionales y de rescatar la discusión griega de la educación para la eudaimonía, es decir, para la felicidad interior entendida como buen ánimo. Con propiedades ubicuas y funciones aditivas por su intensidad y pertinencia, la emoción permite recordar contenidos. Recuperar su centralidad para favorecer el avance de los estudiantes es menester de la academia. En síntesis, el rescate de la emoción y su conexión con la razón sería la clave.

Si ignoramos la emoción, el neocortex requiere, simplemente, de una explicación básica y plana por parte del maestro, relación vertical docente-alumno, toda esta puesta en escena buscaría que los estudiantes entiendan mejor y no corran el riesgo de "perderse". Currículo previamente elaborado, segmentado y estructurado para el neocortex ajeno a los demás estratos del cerebro (límbico y reptiliano), aseguraría el aprendizaje, es lo que ingenuamente se piensa. Cuando la academia separa lo cognitivo de lo emocional, está ejerciendo violencia porque separa lo que está articulado por naturaleza.

Estar emocionalmente perturbados, nos lleva a decir que "no podemos pensar bien" y permite explicar por qué la tensión emocional prolongada puede obstaculizar las facultades intelectuales. Nuestro funcionamiento vital estaría cohabitado por dos tipos de inteligencia: racional y emocional. En razón a la precedencia del cerebro límbico sobre el neocortex en el tiempo, hay más caminos de ida que de regreso, lo que explica la mayor influencia de la emoción, que es primero, sobre la razón, que es después.

The brain [...] in our revolutionary history is such that connections from emotional systems to cognitive systems are stronger than connections from the cognitive system to the emotional system. [...] Finally, once emotions occur they become powerful motivators of future behavior (LeDoux, 1996, p. 19).

Si hay emociones que no estamos en condiciones de filtrar al hacer tránsito del tálamo hacia la amígdala sin pasar por el neocortex, las implicaciones en nuestro sistema de justicia son monstruosas. Es este un punto pendiente que apenas aparece en algunos artículos de revistas especializadas, pero que la sociedad en su conjunto no se ha atrevido a analizar. No es suficiente el descubrimiento científico, es necesario analizar sus implicaciones hasta las últimas consecuencias.

Que los estudiantes sean adaptados a modelos resulta dogmático, antinatural, arbitrario y excluyente, realmente creemos que funciona al revés, bastaría con entender el siguiente principio "no es posible enseñar la emoción en teoría pero sí contagiarla en la práctica, en la interacción con el otro". El pensamiento sin emoción pasa de largo, convierte al estudiante en agelastos y le impide su correcta adaptación de acuerdo con Carretié. 


\subsubsection{Luis Carretié Arangüena}

El funcionamiento y anatomía de la mente humana ha sido un enigma que muchos científicos han intentado descifrar, logrando importantes avances. Carretié, se ha preocupado por rastrear y comprender el funcionamiento cerebral a través de técnicas que permiten observar cómo actúa el cerebro en vivo. Sus investigaciones y resultados giran en torno a la anatomía de la emoción y la cognición.

Las emociones, de acuerdo con Carretié, no solo son esenciales para la correcta adaptación del individuo, sino que, además, son la base que motiva la conducta. Las redes neurales subyacentes a la emoción incluyen conexiones directas con los sistemas motivacionales primarios, que están implicados en la mediación de las conductas básicas (cerebro reptil de acuerdo con MacLean) para la supervivencia de los individuos.

Las emociones presentes en el cerebro reptil (MacLean), llamado por Carretié "circuito de evitación o aversivo", es activado por estímulos amenazantes que propician emociones negativas y se consolidan en conductas de evitación, escape y defensa del organismo. Estos circuitos de evitación, presentan dos mecanismos neurales especializados en el procesamiento urgente de información amenazante: uno subcortical y otro cortical.

Cuando el organismo no puede esperar, opera el sistema Subcortical (vía rápida). Muchas investigaciones han confirmado el funcionamiento de una vía rápida para la transmisión de la información sensorial que conecta directamente a los núcleos sensoriales del tálamo con la amígdala (algunos aducen que el hipocampo juega un papel decisivo en las reacciones frente al miedo), evitando el 'retraso' que supone la implicación o participación de la corteza. Esta vía de reacción urgente es capaz de extraer información global pero suficiente sobre la situación, para permitir al individuo reaccionar rápidamente ante una posible amenaza o peligro inminente para su supervivencia.

Involucrada en la percepción del miedo (llamada por algunos de acuerdo con Amaral (2002) “detector del miedo'), la amígdala es la estructura más importante para el funcionamiento de esta vía rápida. LeDoux (1996) ya había propuesto que la amígdala puede activarse ante estímulos emocionales sin necesidad de que el individuo sea consciente de dicha estimulación. La amígdala provoca respuestas motoras y autonómicas, (moduladas por el hipotálamo) que son necesarias para enfrentar un evento amenazante, posee, además, conexiones con la corteza visual aumentando la asignación de recursos atencionales (LeDoux, 2000).

Cuando se necesita más información sobre la situación, opera la vía lenta o sistema Cortical (vía lenta). Esta vía lenta refleja el funcionamiento de una fase tardía del circuito de evitación. Así, la información se transmite desde el tálamo hacia la corteza conectando esta posteriormente con la amígdala. La participación de la corteza provee información más rica y detallada sobre el estímulo en cuestión que, por tanto, precisa de mayor tiempo para su procesamiento (LeDoux, 1990 - 1996). Leemos en Anatomía de la mente. Emoción, cognición y cerebro: 
La emoción como reacción es por definición un proceso rápido, pero en algunos casos la rapidez debe ser extrema. Ciertos estímulos emocionales, como una amenaza o daño, requieren en movilización intensa y urgente [...] esta urgencia se asocia principalmente a estímulos de carácter negativo [...]. Los eventos displacenteros provocan respuestas más rápidas y prominentes tanto a nivel conductual como cerebral que los no negativos, por lo que cabría hablar de "circuitos urgentes de procesamiento". [...] La tendencia opuesta se aplicaría a los "circuitos de procesamiento profundo" (Carretié, 2011, pp. 107 - 108).

La siguiente figura, ilustra el funcionamiento de los mecanismos que venimos desarrollando.

Figura 6. Representación esquemática del circuito de evitación. Adaptado de Carretié, 2001 funcionamiento de mecanismos

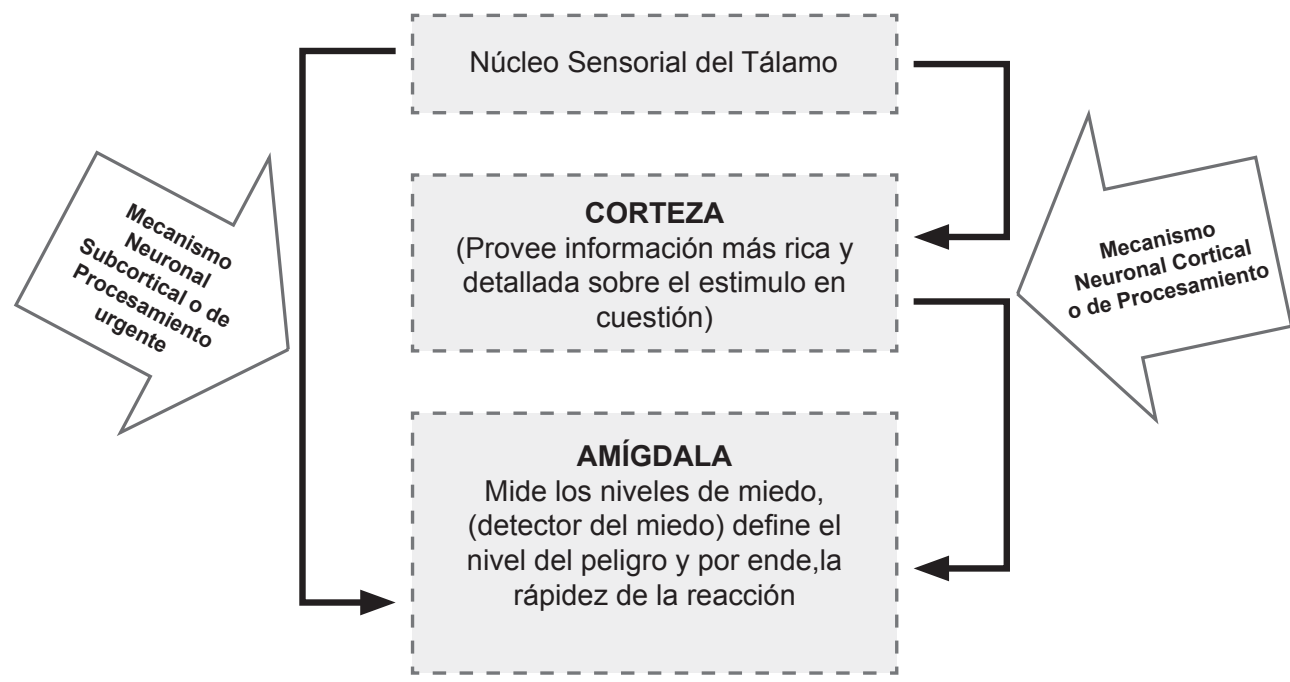

Fuente: la autora

Este esquema, de un lado, evidencia la autonomía de la emoción cuando propone la presencia de mecanismos neurales que omiten la información de la corteza, y del otro lado, pone en tela de juicio antiguas posiciones que argumentan la ausencia de la emoción en la toma de decisiones cuando únicamente quedaría en manos de la razón. Continuamos con Carretié:

La emoción es un fenómeno mental omnipresente, no hay momento del día que no experimentemos algún tipo de emoción, por débil que sea, incluso durante el sueño. La emoción o afecto, puede manifestarse de distintas formas. Puede consistir en una reacción puntual a un evento, como una amenaza (por ejemplo, la parición repentina de un perro ladrándonos), pero también puede consistir en cambios más duraderos [...] como un estado de ánimo que se prolongue durante horas o días (por ejemplo la tristeza) (Carretié, 2011, p. 105). 
Con la ostentación de doble circuito urgente/preciso, la educación no puede menos que generar contextos emocionales que en conexión con la razón, afecten positivamente procesos como la memoria, la motivación y la cognición.

Un estímulo emocional no provoca únicamente una respuesta motora. A la vez que produce la misma, se desencadena a menudo otros procesos afectivos de carácter hedónico (placer- displacer), de carácter motivacional (atracción o deseo frente a rechazo) y de carácter cognitivo (aprendizaje, recuperación de situaciones similares en la memoria...) (pp. 118).

Si la atención depende de la emoción y el nivel de aprehensión de los contenidos depende de la atención, resulta inevitable gestar un giro que recupere la centralidad de la emoción en el acto educativo. Continuamos con Carretié:

Se ha descrito en diversos experimentos cómo la atención tiene preferencia por los estímulos emocionales [...] hemos hablado de que los estímulos significativos (además de los novedosos) tienen la capacidad de capturar la atención [...]. Los estímulos significativos, son, por definición, estímulos emocionales (pp. 145).

Lejos de ejercer poder solo en la atención, la emoción resulta determinante para recordar aquellos contenidos que tanto preocupa a la academia y de los cuales solo unos pocos se encuentran vigentes, pero a pesar de ello no logran ser recordados por la educación repetitiva y bancaria (Freire) que coloniza la educación desde hace varios siglos.

Diversos estudios han mostrado que los estímulos emocionales tienden a ser mejor recordados que los estímulos neutros [...], independiente de su valencia (positiva o negativa) [...] en esta tareas directas o explícitas la amígdala juega un papel importante tanto en la codificación como en la recuperación de estímulos emocionales (pp. 170).

Sin negar el importante papel de los contenidos y de los procesos cognoscitivos en la educación, nos proponemos enfatizar en el reduccionismo cognitivo de la educación. Se hace necesario repensar la educación desde una perspectiva integral que incorpore de manera sustancial lo emocional y afectivo como expresión de la satisfacción de las necesidades del sujeto, de cara a los avances científicos ya registrados y a las implicaciones sociales del asunto de las que se ocupa Maturana.

\subsubsection{Humberto Maturana. Emociones y lenguaje en educación y política}

Que las decisiones que a diario tomamos no solo dependan de la razón, sino, además, de la emoción, que, en concordancia con Philosophy in the Flesh. The Embodied Mind and Its Challenge to Western Thought de Lakoff y Jhonson, no exista nada parecido a la razón pura, cuando no es posible abstraer la vida intelectual de la biología, es uno de los aportes de Maturana. Leemos en Emociones y lenguaje en educación y política: 
Decir que la razón caracteriza a lo humano es una anteojera, y lo es porque nos deja ciegos frente a la emoción que queda desvalorizada como algo animal o como algo que niega lo racional. [...] al declararnos seres racionales vivimos una cultura que desvaloriza las emociones, y no vemos el entrelazamiento cotidiano entre razón y emoción que constituye nuestro vivir humano, y no nos damos cuenta de que todo sistema racional tiene un fundamento emocional [...]. Biológicamente, las emociones son disposiciones corporales que determinan o especifican dominios de acciones (Maturana, 1990, pp. 15 - 16).

Desde cuando Aristóteles definiera al hombre como ser racional, la emoción quedó por fuera de lo específicamente humano. Previamente, Platón había deslindado el alma del cuerpo. Abiertamente comprometida con la corporalidad, la emoción es solapada en consecuencia. No faltan las implicaciones. Continuamos con Maturana.

[... Nos cuesta aceptar el fundamento emocional de lo racional y nos parece que tal cosa nos expone al caos de la sinrazón donde cualquier cosa parece posible. [...] ocurre sin embargo, que el vivir no ocurre en el caos, y que hay caos solamente cuando perdemos nuestra referencia emocional y no sabemos qué queremos hacer, porque nos encontramos recurrentemente en emociones contradictorias (pp. 58).

Que la emoción sin pensamiento se desborde, especialmente porque estaba hecha para un mundo exclusivamente físico, bien puede verificarse en la neurosis. No se trata, no obstante, de adoptar un modelo o un Método con mayúscula para incorporar la emoción a la razón, no se trata de enseñarla en teoría, sino, de contagiarla en la práctica a través de la interacción contando con el contexto sin dejar de lado los elementos retóricos y artísticos (como el teatro y el cine) especialmente dinámicos para tal fin.

La negación de la emoción nos hace indiferentes sociales. Influenciados por el pensamiento occidental, agelastos, inclusive, terminamos rindiendo culto al egoísmo y a la ilegitimidad del otro. Recuperar el protagonismo de la emoción, estabilizaría la convivencia, porque nuestras acciones serían permeadas por el amor.

El amor es la emoción que constituye el dominio de acciones en que nuestras interacciones recurrentes con otro hacen al otro un legítimo otro en la convivencia. Las interacciones recurrentes en el amor amplían y estabilizan la convivencia [...]. Finalmente, no es la razón lo que nos lleva a la acción sino la emoción (pp. 23).

Si la emoción es acción, si no es un oscurecimiento ni restricción de la razón, si la razón nos hace miopes frente a las necesidades del otro, si la academia nos hace "competentes" racionales e incompetentes sociales por conducto de la razón, es menester reconocer el poder de emociones como el amor en la construcción legítima del otro, en vez de reprimirla o hacerla un invitado fantasma en la vida social y en el acto educativo. Resulta perentorio promover la justicia social, poner en entredicho prácticas pedagógicas excluyentes que educan para la competencia y no para la convivencia. 
Uno hace de su vida estudiantil un proceso de preparación para participar en un ámbito de interacciones que se define en la negación del otro bajo el eufemismo: mercado de la libre y sana competencia. La competencia no es ni puede ser sana porque se constituye en la negación del otro. La sana competencia no existe. La competencia es un fenómeno cultural y humano y no constitutivo de lo biológico. Como fenómeno humano la competencia se constituye en la negación del otro (pp. 13).

Lejos de ser natural, la actual crisis social que enfrenta el mundo, en general, y Colombia, en particular, es la prueba de que estamos educando al revés. Sin más valor que el del dinero, los estudiantes quedan atrapados en el consumismo y la competencia que desmembra cada vez con mayor rapidez la cohesión social, el respeto por las diferencias y el reconocimiento del otro como ser humano valioso y necesario en nuestra existencia. Somos producto del educación y de la publicidad, la una nos estrena para producir y la otra consumir.

[...] El fenómeno de competencia que se da en el ámbito cultural humano y que implica contradicción y negación del otro, no se da en el ámbito biológico [...]. La victoria es un fenómeno cultural que se constituye en la derrota del otro. La competencia se gana cuando el otro fracasa frente a uno, y se constituye cuando el que eso ocurra es culturalmente deseable. En el ámbito biológico no humano ese fenómeno no se da. La historia evolutiva de los seres vivos no involucró competencia. Por esto, en la evolución de lo humano no participa la competencia [...] (pp. 21 - 22).

Para convivir en una sociedad democrática y garantizar unas relaciones afectivas saludables en un entorno social y cultural cada vez más dinámico y plural, es necesario desabastecer la sociedad y la academia de aquellas competencias que ilegitiman al otro y su multiplicidad humana. A la competencia racional y capitalista que nos descuartiza a la velocidad del vértigo, Maturana opone el amor propio de la convivencia a partir de la emoción.

La emoción fundamental que hace posible la historia de hominización es el amor [...]. El amor es el fundamento de lo social [...]. El amor es la emoción que constituye el dominio de conductas donde se da la operacionalidad de la aceptación del otro como un legítimo otro en la convivencia [...]. El amor es la emoción que funda lo social; sin aceptación del otro en la convivencia no hay fenómeno social. [...] solo son sociales las relaciones que se fundan en la aceptación del otro como un legítimo otro en la convivencia (pp. 24).

Sabemos que el mundo ha cambiado, que hay apuestas y no caminos ni certezas, que la emoción hace parte de las funciones de nuestro sistema nervioso, que la razón depende de la emoción, que la competencia no puede ser sana, que el amor y la convivencia son parte de nuestra información genética. De ser reprimida la emoción, difícilmente recordamos y no habría de dónde extraer la motivación. El conocimiento debe emocionar para no terminar olvidándose.

Que la “emoción’ no corresponda solamente a un proceso cerebral separado e independiente, 
sino al resultado de múltiples mecanismos sinápticos, no necesariamente conscientes (lo que Freud llamó 'el inconsciente'), los mismos que determinan de manera decisiva las características conscientes del pensamiento, haría que nos ocupemos de la riqueza y complejidad de la mente humana como en efecto lo hace Howard Gardner cuando a través de su teoría sobre las inteligencias múltiples actualiza la idea de inteligencia.

Finalmente, que la formación de la humanidad, esté directamente relacionada con el desarrollo personal, que el autorrespeto y la legitimación del otro sean prerrequisitos para la construcción de una sociedad incluyente e integral, son algunos de los valiosos aportes de Maturana a la sociedad, en general, y a la educación, en particular. Un no rotundo a la "competencia" por las connotaciones de negación del otro a la que conlleva, es una posición que compartimos completamente, sin embargo, ¿cómo expulsarla de la educación cuando vivimos en una sociedad que cada vez tiene más rankings? ¿cómo entrenarlos por fuera de la competencia cuando se enfrentan a ella a diario? $i$ corren el riesgo de quedar sin herramientas que les permita enfrentarse a las exigencias competitivas que pueden llegar a determinar su supervivencia?

\subsubsection{Howard Gardner. Intelligence Reframed. Multiple intelligences for the 21 st century}

La teoría de las inteligencias múltiples, propuesta por Gardner, iniciada en los años 80, pluraliza el concepto tradicional de inteligencia. Definida inicialmente como la habilidad para resolver problemas o para elaborar productos que son de importancia en un contexto cultural o en una comunidad determinada, fue reformulada algunos años después como el potencial biosociológico para procesar información que se puede activar en un marco cultural para resolver problemas o crear productos que sean valiosos en una cultura. Este potencial biosociológico, que hace la diferencia con respecto a la primera definición de inteligencia, puede ser o no activado dependiendo, entre otros, de la cultura, de las decisiones personales, familiares y de los profesores, inclusive. Con el protagonismo del potencial biosociológico, Gardner propone una teoría incluyente no solo de la dotación bilógica, sino además, cultural, lo que representaría un punto de encuentro con MacLean, Damasio, LeDoux y Carretié en el primer caso, y con Maturana en el segundo caso.

Todas las personas poseen la totalidad de este espectro de inteligencias, de acuerdo con Gardner. Cada una desarrollada de un modo y a un nivel particular, producto de la dotación biológica del individuo, de su interacción con el entorno y de la cultura imperante en su momento histórico. Todas estas inteligencias se combinan y se usan en diferentes grados, de manera personal y única. Que Gardner base su teoría en la Ciencia del conocimiento, la Psicología y la Neurociencia, que las neuronas trabajen de diferentes formas al procesar la información, haría que nos ocupemos de una nueva educación que actualice la idea de inteligencia y brinde protagonismo a las diferencias. De lo contario continuamos desarrollando solo aquellas relacionadas con la razón, es decir, la lógica y las estructuras lingüísticas. Leemos en Intelligence Reframed. Multiple intelligences for the 21st century. 
We are not all the same, we do not all have the same kinds of minds, [...] and education works most effectively for most individuals if these are differences are taken into account rather than denied or ignored. [...] in education, the challenge of the next millennium consists precisely in this: Now that we know about the enormous differences in how people acquire and represent knowledge, can we make these differences central to teaching and learning? Or will we instead continue to treat everyone in a uniform way? If we ignore these differences, we are destined to perpetuate a system that caters to an elite - typically those who learn best in a certain, usually linguistic or logical-mathematical manner. On the other hand, if we take these differences seriously, each person may be able to develop his or her intellectual and social potential mucho more fully (Gardner, 1999, pp. 91 - 92).

De la rigidez del currículo, también se ocupa Gardner y señala la educación actual no solo de ser repetitiva y descontextualizada, sino, además, de contener currículos que evitan a toda costa los contenidos contextualizados, nuevas conexiones neuronales y estimulaciones acordes a los estudiantes. El currículo, de acuerdo con Gardner, debe facilitar el desarrollo y la optimización de las capacidades individuales.

An "MI setting" can be undone if the curriculum is too rigid or if there is buy a singles form of assessment [...] A program rich in the arts should assume a significant role in the school. Otherwise, it will be difficult to address the range of intelligences exhibited by students and teachers. [...] There is one form of education that is antagonistic in spirit to MI - the uniform [...] The essence of uniform schooling is the believe that every individual should be treated in the same way: study the same subjects in the same way and be assessed in the same way. At fists, this seems fair: No one has special advantages. [...] those who ignore the differences are not being fair - and are typically focusing only on the language-logic mind (pp. 147 - 50).

En concordancia con Bauman (2002) y Lipovetsky (2007), Gardner reconoce la existencia de una sociedad contingente que se trasforma a la velocidad del vértigo. Educar no solo para el cambio, sino, además, para las diferencias sería la clave: "education in our time should provide the basis for enhanced understanding of several worlds - the physical world, the biological world, the world of human beings, the world of human artifacts, and the world of the self (pp. 158).

Su preocupación por el tipo de educación que los estudiantes reciben en la actualidad y la forma como los contenidos son abordados, lo ha llevado a formular varias inteligencias y estrategias metodológicas en consecuencia. En conversación sostenida con el Dr. Gardner en Harvard, tuve la ocasión de consultarle sobre la pertinencia que podía tener la conexión emoción-razón en el marco de las inteligencias múltiples. Al enfatizar en la dinámica de las inteligencias múltiples, el Dr Gardner, identificó en la dinámica emoción-razón, una de sus interacciones básicas.

Después de advertir las diferencias emocionales, culturales y cognitivas del ser humano, 
Gardner reconoce la efectividad de la educación cuando actúa desde tres puntos clave las diferencias personales, mentales y actuar en consecuencia. Leemos en Intelligence Reframed. Multiple intelligences for the 21ts century:

I regard MI theory as a rising endorsement of three key positions: we are not all the same, we do not all have the same kinds of mind [...] and education Works most effectively is these differences are taken into account rather than denied or ignored (Gardner, 1999, p. 91).

Lejos de concebir la escuela como único espacio para desarrollar la inteligencias, permite reflexionar y ser conscientes del papel que desempeñan otros lugares, no solo para la aprehensión del conocimiento, sino, además, para favorecer la cohesión social tan ausente por esta época:

Multiple intelligences can be mobilized at school, at home, at work, or on the Street - that is, throughout the various institutions of society. [...] but the task of the new millennium is not merely to hone our various intelligences and use them properly. We must figure out how intelligence and morality can work together to create the world in which a great variety of people will want to live (pp. 4).

Gardner plantea que las inteligencias múltiples son un medio para comprender el funcionamiento de nuestra mente y ahondar nuestra comprensión del mundo, no solo el físico, sino, además, el de la expresión humana. Formuladas primero 6 inteligencias y adicionando luego 2, en la actualidad habla de 8 inteligencias múltiples:

Las dos primeras inteligencias son aquellas que la academia ha señalado como únicas y verdaderas: inteligencia lingüística e inteligencias lógico-matemática. Otras tres inteligencias están particularmente relacionadas con las artes: inteligencia musical, inteligencia corporalkinestésica y la inteligencia espacial. Dos inteligencias se relacionan con lo social: inteligencia intrapersonal e inteligencia interpersonal. La Inteligencia naturalista, sería la última en ser formuladas.

No se trata de satanizar la inteligencia lógica y lingüística, sino de abrir paso a otras inteligencias que le permitan al estudiante aprender de la forma como le es más fácil. Cambiar el enfoque del proceso de enseñanza - aprendizaje, al aplicar el concepto de las inteligencias múltiples, desarrollar diferentes estrategias en la entrega de contenidos, evaluar en consecuencia y adoptar currículos flexibles, resulta perentorio para Gardner. Que los estudiantes aprenden de acuerdo a la inteligencia o inteligencias que tienen más desarrolladas, no solo los hace más felices favoreciendo la cohesión social, sino que, además, gestaría la conexión emoción-razón que hemos defendido a través de todo el documento.

En síntesis, la neurociencia, la teoría de las inteligencias múltiples y la educación convergen en muchos aspectos. Si el hombre no tiene dos sino tres cerebros, si la emoción participa en 
la toma de decisiones racionales, si el neocortex nos brinda claridad, si la motivación y la memoria dependen en gran medida de la de la emoción, ¿ por qué no actuar en consecuencia? ¿Por qué continuar ignorando cuando no expulsando la emoción del plano educativo?

Sin embargo, colocar en tela de juicio el reinado de la inteligencia racional, cuyos orígenes se remontan a los filósofos clásicos griegos, es un aporte de indiscutible valor, en un mundo pluralista como el que aspiramos habitar. Hablar, entre otras, de inteligencia emocional, inteligencia artística, inteligencia kinestésica o inteligencia espacial, tiene indiscutible valor. Hay quienes creen, no obstante, que lo que hace inteligente al ser humano no son una o varias de las inteligencias particulares, sino, la inteligencia trasversal como refiere Steven Mithen en su libro Arqueología de la mente, cuando se ocupa de contestar a la pregunta ¿qué hizo al hombre tal? 


\section{Implicaciones Educativas}

\subsection{Metodología}

Este trabajo se inscribe en la investigación-acción participativa, reflexiva y cualitativa en la que sus participantes (docentes y estudiantes) no solo construyen sentidos individuales y colectivos, sino, además, contextos compartidos que favorecen sus propias trasformaciones a través de un círculo hermenéutico de continua evaluación, enriquecimiento y resignificación de las realidades que enfrentan.

Adoptamos una metodología cualitativa de un lado, porque concibe el ser humano como sujeto plural y holístico, y del otro lado, porque le permite al investigador afinar olfato, ajustarse constantemente al cambio y comprender sus interacciones en contexto ampliando sus horizontes de sentido. Las mencionadas bondades de este tipo de investigación, han sido registradas por Deslauriers en Investigación cualitativa:

[...] La investigación cualitativa rescata la subjetividad y reconoce que lo social no puede ser cuantitativo porque son las personas quienes apuestan y construyen sus propias realidades sociales [...] el estudio del sistema viviente que es la sociedad, requiere que la metodología sea flexible [...]. El plan de investigación puede evolucionar al mismo tiempo que la investigación por sí misma responde a las necesidades que se presente. Esta flexibilidad se revela como una gran ventaja, porque el estudio de un ser viviente implica un componente imprevisto al cual hay que ajustarse [...] (Deslauriers, 2004, pp. 14).

Vivimos en una sociedad gobernada por el tiempo líquido, la felicidad líquida (Bauman, 2002) y paradójica y un consumo emocional (Lipovetsky, 2003) que parece no tener fin. Si la sociedad cambia a la velocidad del vértigo, si hemos dejado de ser ingenuos con respecto la manipulación del lenguaje, si los estudiantes reclaman cambios educativos y sociales, es necesario adoptar estrategias que no solo les permita pensar los cambios, sino, además, intervenirlos.

Recuperar el protagonismo de la emoción y los efectos perlocucionarios del enunciado en el la interacción educativa escolar, conectaría con la cultura y la tradición intelectual; ¿por qué la academia continúa estacionada reprimiendo la emoción, administrando educación bancaria y repetitiva, concediendo a la lógica un poder arrasador y haciendo del estudiante un invitado fantasma?

Incluir la emoción y la motivación en las prácticas pedagógicas, evita el castigo de la educación con características de eco, porque la motivación favorece la memoria si nos atenemos a Damasio (2005). La academia no solo simplifica mundo y robustece el objetivismo en detrimento del subjetivismo, sino que, además, olvida que en las áreas humanísticas no hay 
certezas, probablemente se haya dado un proceso de colonización de las ciencias duras.

Orientar humanidades con estratagemas de ciencias básicas, recorta los hombres y sus opciones de futuro, refuerza lo lineal acelerando el anacronismo educativo. El desfase de enseñar sobre apuestas de la misma manera que se enseña sobre certezas, uniforma el pensamiento y olvida que los seres humanos y las sociedades son mundos distintos.

Figura 7. Algunas diferencias entre ciencias exactas y humanidades
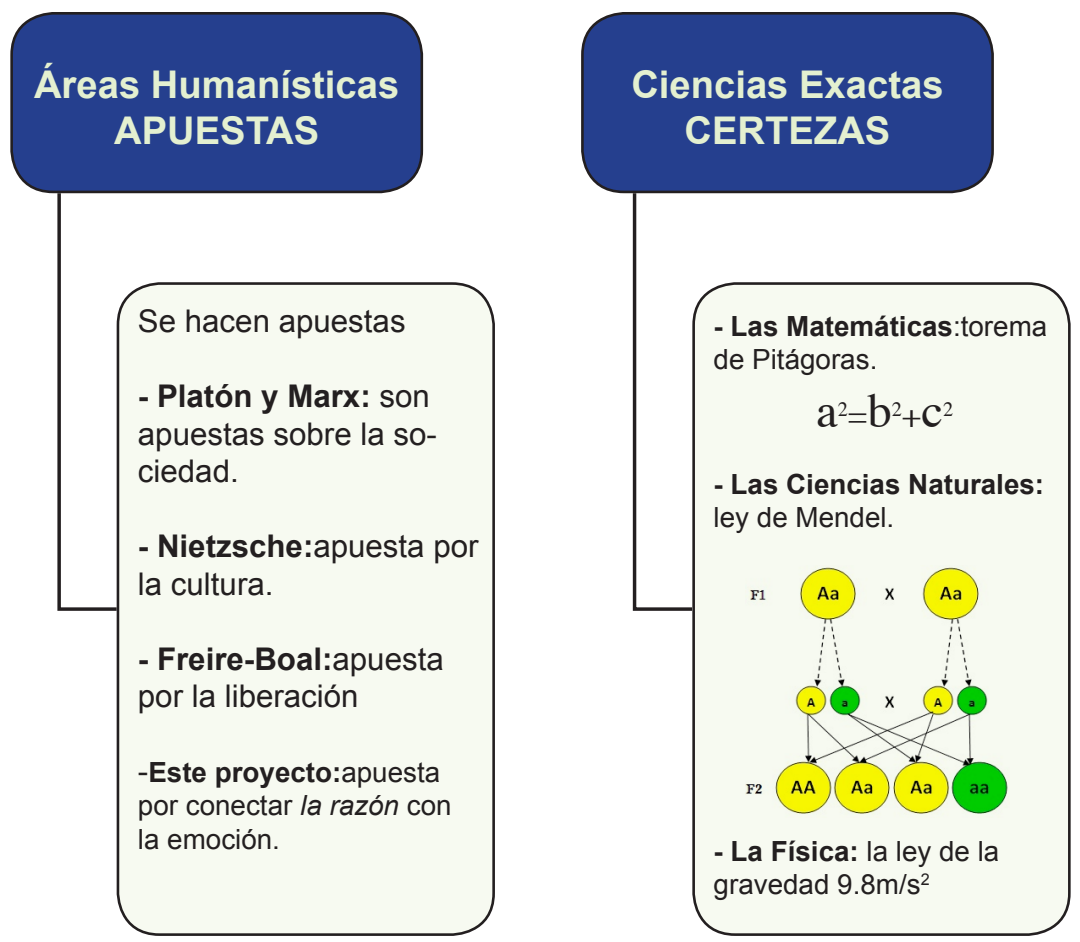

Fuente: la autora

Mientras las áreas técnicas volcadas sobre el mundo buscan mejorar las cosas, las humanidades pretenden cambios en el hombre. No pretendemos gestar la fragmentación epistemológica entre áreas humanísticas y ciencias exactas, sino, una distinción que nos permita valorar sus divergencias y reconocer las convergencias actuales como las crisis de las certezas en ambas áreas, el bosón de Higgs o partícula de Higgs, que dejó en entredicho el funcionamiento del modelo estándar de la física, al mejor estilo de las humanidades, sería una de ellas.

En concordancia con las ideas de sociedad contingente, futuro impredecible y plural y flexibilidad educativa y pedagógica, de un lado, y sabiendo que el proceso investigativo es una aventura en la que no es posible predecir con exactitud lo que sucederá, del otro lado, 
a continuación se presentarán dos rutas metodológicas: la Ruta metodológica ideal, que fue planeada con detenimiento (gráfico 6) y la Ruta metodológica real (gráfico 7) que refleja cada una de las bifurcaciones, alteraciones y desvíos que sufrió la Ruta metodológica ideal. Ambas permiten una mirada del proceso investigativo de principio a fin. Los sucesivos gráficos profundizan en cada una de las fases planteadas en las rutas metodológicas y las formas como se interactuó con los datos y conocimientos aprehendidos a través de los seminarios doctorales, las conversaciones con el asesor, las recomendaciones de los jurados y en general, las nuevas lecturas y experiencias en clase mientras se aplicaban las nuevas exploraciones.

Figura 8. Ruta metodológica ideal
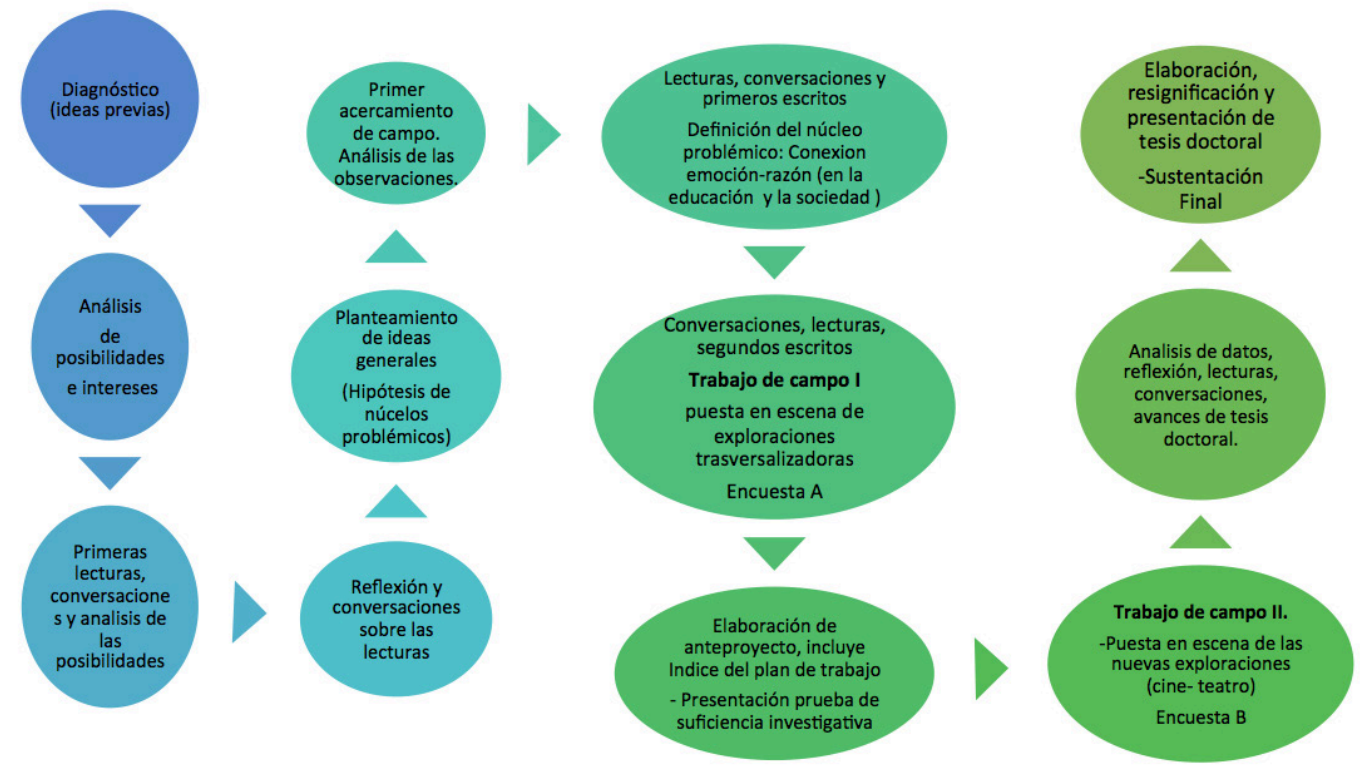

Fuente: la autora 
Figura 9. Ruta metodológica real

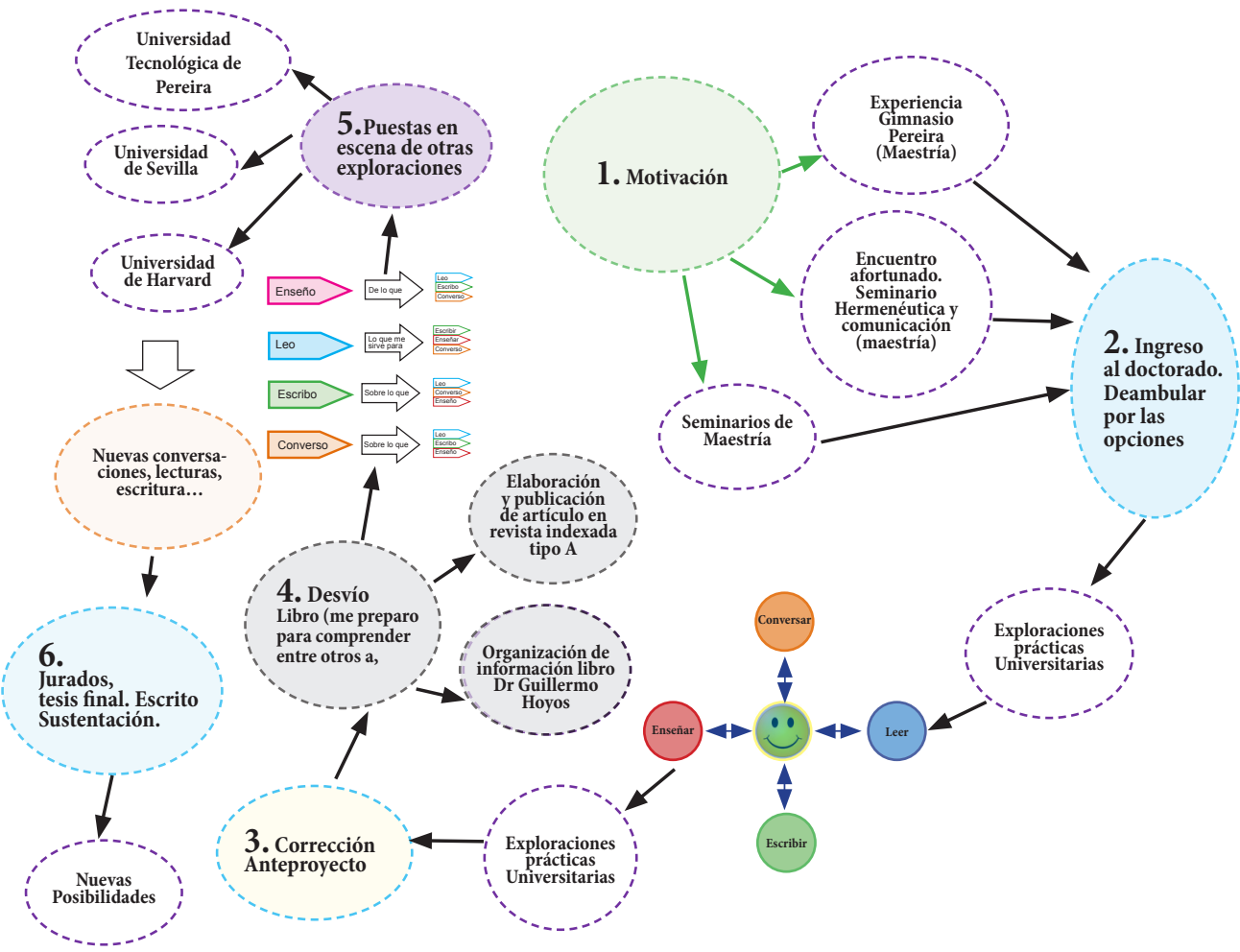

Fuente: la autora

Sabemos que en las humanidades no se puede aspirar a tener certezas porque se necesitarían aquellas que fueran válidas para todos los casos y eso no es posible en este campo. Que las humanidades estén siendo abordadas como ciencias exactas, explicaría el dominio de la educación bancaria, el estilo plano y la ausencia de la pragmática lingüística en el ámbito escolar.

Si el consumo ha adquirido un fin en sí mismo, y en particular, como consumo emocional (Lipovetsky, 2003), si la emoción es protagonista, si las humanidades han sucumbido frente a las ciencias exactas, es menester adelantar estrategias metodológicas que recuperen la centralidad de las humanidades y proporcione nuevos discursos y nuevas prácticas pedagógicas que conviertan la academia, no solo en escenario propicio para la adquisición de conocimientos a través de la conexión emoción - razón, sino, además, para la emancipación y la construcción de una nueva sociedad.

Que la educación favorezca la humanización, la liberación de los individuos y su inclusión en la sociedad, que la investigación y el quehacer pedagógico sean las dos caras de la misma 
moneda, son planteamientos freirianos que direccionaron los móviles metodológicos aquí propuestos. Leemos en Pedagogía de la autonomía:

No hay enseñanza sin investigación ni investigación sin enseñanza. Esos quehaceres se encuentran cada uno en el cuerpo del otro. Mientras enseño continúo buscando, indagando. Enseño porque busco, porque indagué, porque indago y me indago. Investigo para comprobar, comprobando intervengo, interviniendo educo y me educo. Investigo para conocer lo que aún no conozco y comunicar o anunciar la novedad [...]. Hoy se habla, con insistencia, del profesor investigador. En mi opinión lo que hay de investigador en el profesor no es una calidad o una forma de ser o de actuar que se agregue a la de enseñar. La indagación, la búsqueda, la investigación, forman parte de la naturaleza de la práctica docente. Lo que se necesita es que el profesor, en su formación permanente, se perciba y se asuma, por ser profesor, como investigador. La práctica docente crítica, implícita en el pensar acertadamente, encierra el movimiento dinámico dialéctico entre el hacer y el pensar sobre el hacer (Freire, 1997, p 30).

No es accidental, pues, que la metodología, de un lado, presente en las siguientes páginas, varios móviles que dinamizan y dan sentido al quehacer pedagógico, y del otro lado, gire alrededor tres exploraciones fundamentales: el cine, el teatro del oprimido y las exploraciones transversalizadoras (que están presentes en las dos primeras). Cada una de estas nuevas exploraciones pedagógicas, busca además, que los estudiantes avancen en su proceso de formación profesional y humana, mientras disfrutan su paso por la vida estudiantil universitaria.

Figura 10. Nuevas exploraciones

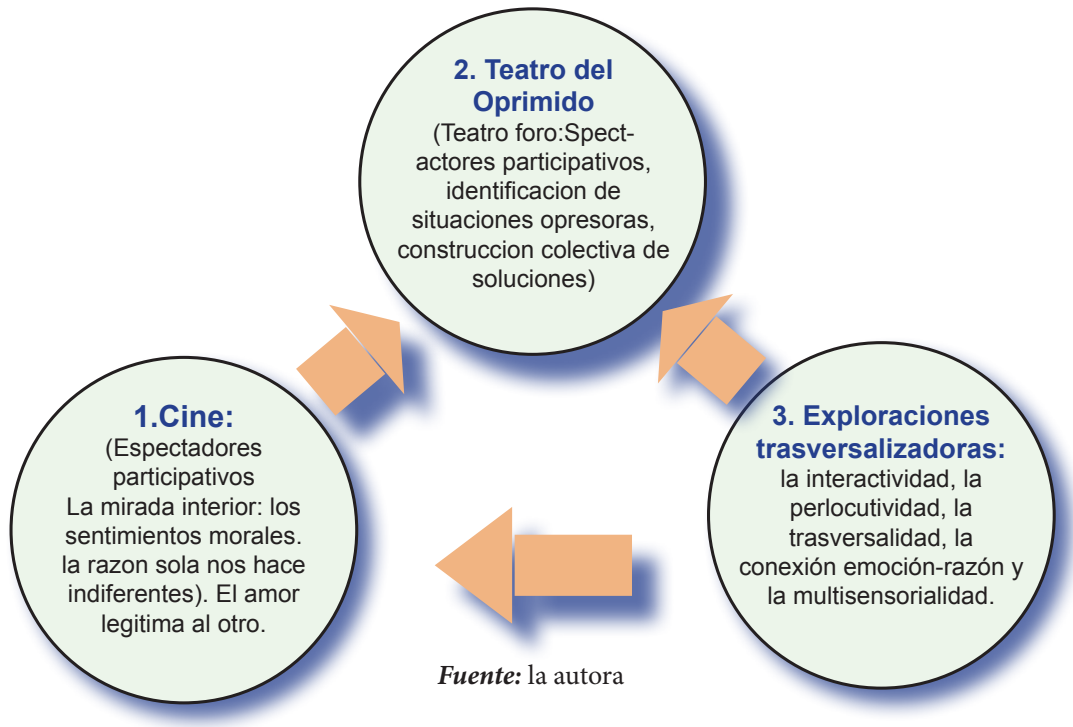


Cada una de las nuevas exploraciones (el cine, el teatro del oprimido y las exploraciones) será objeto de evaluación y resignificación constante de cara a las necesidades y evolución de los estudiantes. La característica más importante de ésta propuesta metodológica es la posibilidad de iniciar en cualquiera de los procesos (enseño, leo, escribo y converso), convirtiendo cada uno de los cuatro, en consecuencia de los otros tres.

Si las disciplinas socioculturales no se pueden enseñar como si fueran ciencias duras como las matemáticas, entonces es necesario poner en marcha móviles flexibles como los que se proponen a continuación porque permiten reconocer a través del proceso investigativo que lo que enseño, leo, escribo y converso; son procesos simultáneos que asciende en forma de espiral pasando por el mismo lugar pero con un nivel superior de comprensión permitiendo la continua evaluación, adaptación y reconstrucción del proceso investigativo en general, y de la metodología, en particular.

Figura 11. Vista frontal del móvil

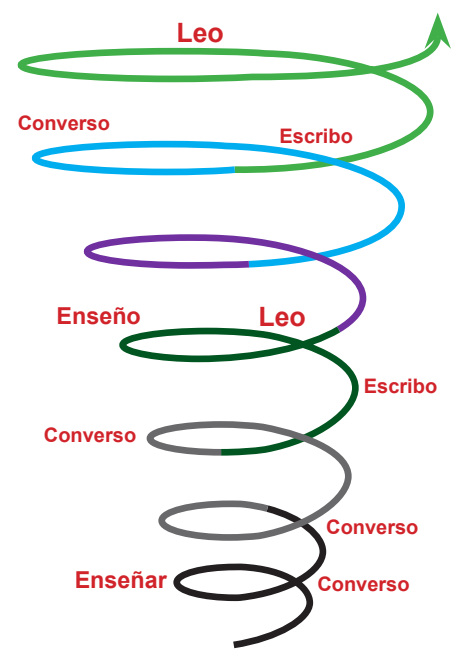

Figura 12. Vista cenital del móvil

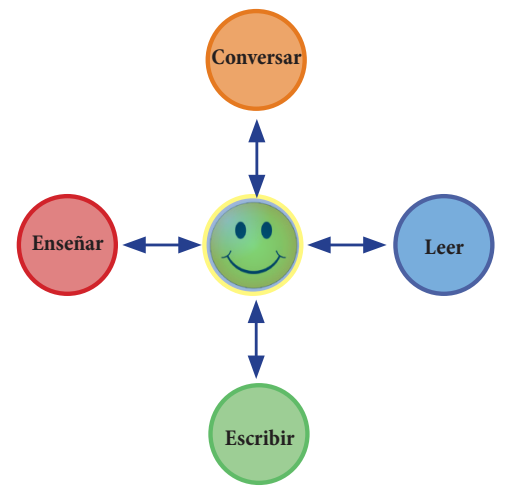


La secuencia de este móvil metodológico se puede leer, entre otras, de las siguientes formas:

Figura 13. Lecturas del móvil

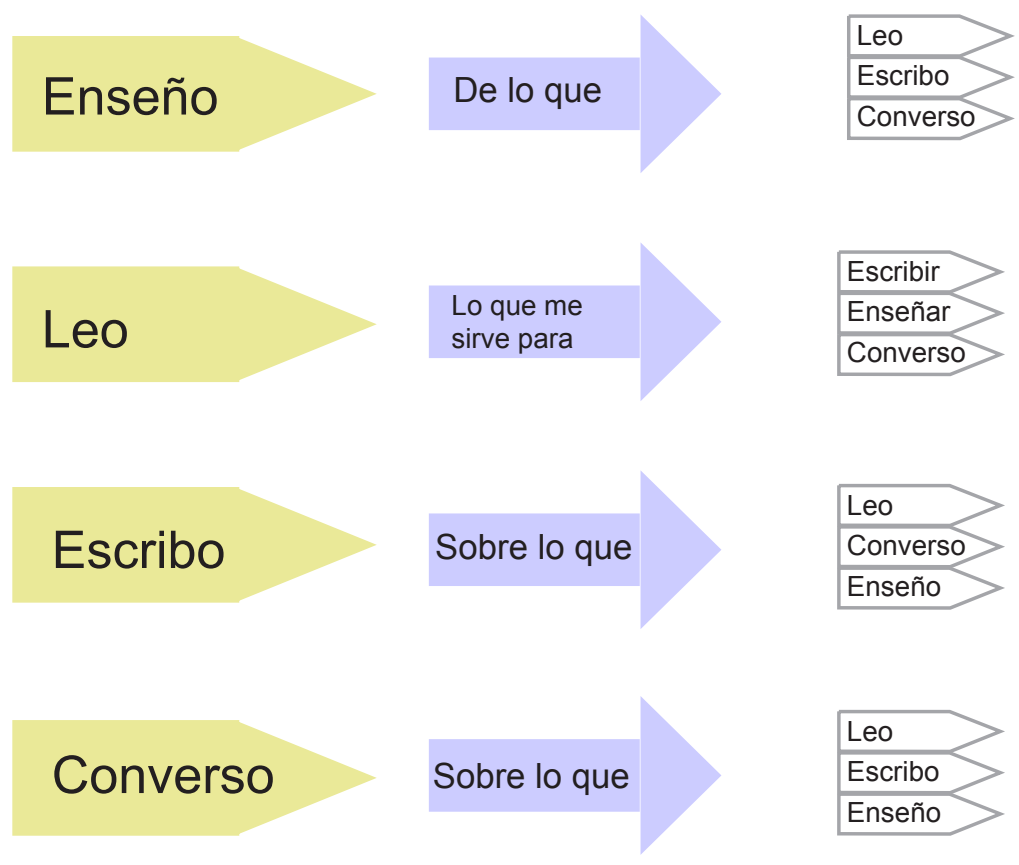

Fuente: la autora

Los puntos de lectura y escritura tienen que ver con la elaboración de los capítulos, el enseñar con las nuevas propuestas pedagógicas y el conversar sobre los puntos de lectura y escritura y resultados parciales de la puesta en escena al enseñar; permitiendo evaluar, retroalimentar y adaptar constantemente el proceso investigativo.

Convencidos que la academia en el escenario propicio para favorecer la conexión emociónrazón a través de prácticas pedagógicas interactivas, anti opresivas, liberadoras y lenguajes provocadores que movilicen el estudiante y repercutan en la formación de seres humanos felices, libres y comprometidos con la construcción de una mejor sociedad, mencionamos las presunciones (hipótesis) más relevantes hasta el momento:

\subsection{Suposiciones o hipótesis}

La emoción es el elemento que conecta los desbordantes cambios de la sociedad, las nuevas miradas del lenguaje y la educación. 

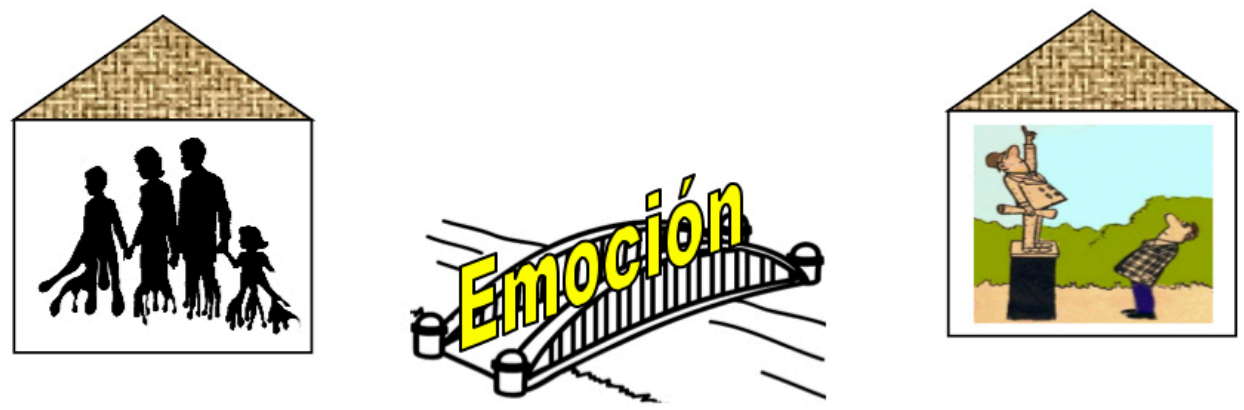

- Hay emociones que cierran y otras que abren, las que abren son aquellas que queremos conectar con la razón.

- La ubicuidad de La emoción puede verificarse en las nuevas tendencias del consumo y en el lenguaje cotidiano.

- La academia reprime la emoción, el consumismo emociona a costos muy altos, la educación lo haría de modo gratuito y encimaría la conexión con la razón, por medio de prácticas liberadoras y participativas.

- El arte a través del cine y el teatro es una opción para contrarrestar el déficit motivacional de las éticas cognoscitivas.

- La educación universitaria no solo debe ser profesionalizante e investigativa, sino, además, humanizante.

- La competencia humana en detrimento del otro, no es natural, es cultural, educar en el amor para la convivencia humana sería la clave.

- Si el futuro de los estudiantes no está determinado en su origen, si la agresión no es la emoción fundamental que define lo humano, sino el amor y la coexistencia en la aceptación del otro como un legítimo otro, se hace necesario que la academia reconsidere la educación y el educar en consecuencia.

Se pretende evaluar no solo el impacto de las tres exploraciones en el proceso de aprendizaje, sino, además, en las emociones de los estudiantes, en el compromiso y las soluciones construidas.

\subsection{Población}

Los integrantes de los grupos con quienes se desarrolló el proceso investigativo y se aplicaron las exploraciones el cine, el teatro y las exploraciones transversalizadoras: la interactividad, la perlocutividad, la transversalidad, la conexión emoción-razón y la multisensorialidad) y posteriormente dos encuestas fueron estudiantes de diferentes semestres de dos licenciaturas 
(en pedagogía Infantil y en informática y comunicación educativa) de la Universidad Tecnológica de Pereira. Las asignaturas específicas fueron:

De la Licenciatura en Pedagogía Infantil:

- Concepciones y Políticas de Infancia, semestre 1.

De la Licenciatura en Informática y Comunicación Educativa:

- Teorías cognitivas, semestre 3.

- Evaluación del aprendizaje, semestre 4.

\subsection{Técnicas de recolección de datos}

Las técnicas adoptadas fueron minuciosamente pensadas y seleccionadas con el objetivo de lograr su complementación y favorecer una investigación seria, objetiva y completa. La encuesta, la evaluación docente aplicada por la universidad a los estudiantes, el video, el audio, la entrevista, las conversaciones informales, la observación directa, el diario de campo y la fotografía son las más importantes.

- La encuesta. Se aplicaron dos encuestas una al iniciar el proceso investigativo (semestre A de 2012) en adelante encuesta A y la otra al finalizar el proceso investigativo (semestre B de 2014), en adelante encuesta B.

- Las encuestas (resultados) de la evaluación docente de los dos grupos con quienes se desarrollaron las nuevas exploraciones.

- Video, fotografía y audio: se grabaron en todas las modalidades, algunas actividades que posteriormente fueron analizadas y que sirven como evidencia del proceso investigativo.

- Entrevistas y conversaciones informales. Con estos instrumentos, se rastrean las percepciones de los estudiantes con respecto a la educación que reciben y la sociedad que viven.

- La observación directa (durante las clases), el diario de campo, las fotografías, los videos propios y elaborados por los estudiantes son otras técnicas que nos permiten recolectar información valiosa.

El siguiente gráfico permite una mejor comprensión de la forma como se aplicaron las encuestas y las nuevas exploraciones de las que nos ocuparemos más adelante. 
Figura 14. Relación de técnicas y exploraciones aplicadas

\begin{tabular}{|c|c|c|c|c|}
\hline Tiempo & Licenciatura & Asignatura & Semestre & Técnica o exploración aplicada \\
\hline $\begin{array}{c}\text { Semestre A } \\
\text { de } 2012\end{array}$ & $\begin{array}{c}\text { Pedagogía } \\
\text { Infantil }\end{array}$ & $\begin{array}{c}\text { Concepciones y } \\
\text { Políticas de } \\
\text { Infancia }\end{array}$ & 1 & $\begin{array}{l}\text { - El cine } \\
\text { - Exploraciones trasversalizadoras (la } \\
\text { interactividad, la perlocutividad, la trasver- } \\
\text { salidad, la conexión emoción-razón y la } \\
\text { multisensorialidad) } \\
\text { - Encuesta A }\end{array}$ \\
\hline Semestre & $\begin{array}{c}\text { Informática y } \\
\text { comunicación } \\
\text { educativa }\end{array}$ & $\begin{array}{c}\text { Teorías cognitivas } \\
\text { (la encuesta se } \\
\text { aplicó el semestre } \\
\text { siguiente en la } \\
\text { asignatura evalua- } \\
\text { ción del aprendizaje } \\
\text { de semestre 4, en la } \\
\text { que también fueron } \\
\text { puestas en escena } \\
\text { las exploraciones } \\
\text { transversalizadoras) }\end{array}$ & 3 & $\begin{array}{l}\text { - El cine } \\
\text { - Teatro del oprimido } \\
\text { interactividad, la perlocutividad, la trans- } \\
\text { versalidad, la conexión emoción-razón y la } \\
\text { multisensorialidad) } \\
\text { - Encuesta B }\end{array}$ \\
\hline
\end{tabular}

\subsection{Exploraciones transversalizadoras}

\subsubsection{Elementos comunes a las exploraciones propuestas}

La interactividad, la perlocutividad, la transversalidad, la conexión emoción-razón y la multisensorialidad, son elementos presentes desde el inicio de la investigación y comunes en las nuevas exploraciones de un lado, porque facilitan la multiplicidad de relaciones en el acto educativo y del otro lado, porque permiten a todos sus actores (docentes y estudiantes) asumir un papel protagónico en el que no solo estén inmersos los conocimientos, sino, además, las emociones individuales y colectivas.

\subsubsection{Interactividad}

La confianza, la empatía, el buen humor y los espacios en los que el estudiante pueda participar y exponer sus puntos de vista y comprensiones, le brinda un ambiente de confianza lleno de emociones positivas que aumentan su comprensión y compromiso. Lograr la interactividad es un compromiso educativo y docente de alta rigurosidad, toda vez que se debe encontrar el justo medio (Jullien) de suerte que las interacciones (discusiones sobre un tema o situación) no sean muy desconocidas como para que los estudiantes se pierdan, ni tan básicas como para que pierdan la motivación. Este justo medio, se logra cuando el docente no pierde de vista lo que Vigotski llama la Zona de Desarrollo Próximo (ZDP), gracias a la cual el docente puede considerar dos niveles en la capacidad del estudiante: el límite de lo que él solo puede hacer, denominado Zona de Desarrollo Real. (ZDR) y el límite de lo que puede hacer con ayuda de alguien más capacitado o con mayor formación llamado Zona de Desarrollo Potencial (ZDP). De la misma forma, la relevancia de la Zona de Desarrollo Próximo en la interactividad resulta determinante en el acto educativo porque es el escenario apropiado para que el estudiante participe con sus presaberes y aprehenda otros nuevos. En síntesis, la interactividad aumenta 
su efectividad cuando de un lado, se desarrolla teniendo en cuenta la Zona de Desarrollo Próximo (individual y colectiva) en la que el estudiante es un agente que genera y recibe nuevos conocimientos y del otro lado, cuando se proporcionan temas polémicos, sensibles y sociales que atrapan sus motivaciones y emociones.

\subsubsection{Perlocutividad}

Lejos de conformarnos simplemente con "decir algo", nos interesa trascender los horizontes de sentido e intencionalidad (lo ilocutivo) y lograr efectos perlocutivos. Los actos de habla planteados por Austin, resultan ser un elemento crucial para comprender la importancia de lo perlocucionario como posibilidad de generar comportamientos, consecuencias o cambios en los estudiantes para no quedarnos en la mera emisión de sonidos que pasan de largo. Cada expresión que la docente ofrece a sus estudiantes, va cargada de lenguaje provocador (sentimientos, emociones, metáforas, ironías, otras figuras retoricas, dobles sentidos) que pretenden despertar del adormecimiento de lo locucionario y estimular "el actuar" en consecuencia. Elementos prosódicos como el tono de voz, el acento, el ritmo y litúrgicos como la puesta en escena en general, la organización de los escritorios, la distribución en el tablero, la velocidad del desplazamiento por el espacio de clase y el material utilizado (lecturas cortas, imágenes grandes, sonidos llamativos) acorde a sus intereses y necesidades resultan determinantes para captar la atención, motivar y lograr efectos perlocucionarios. En síntesis, el lenguaje toma la centralidad en el acto educativo y se pretende no solo decir, sino, además hacer cosas con palabras (Austin).

\subsubsection{Transversalidad}

Conscientes de la pluralidad humana, cada una de las exploraciones y las teorías inclusive, logran comunicarse con otras áreas del saber, creando redes de sentido que favorecen la coherencia, la interacción entre los conocimientos y las emociones ampliando los horizontes de sentido. En el campo humanístico particularmente las fronteras disciplinarias son difusas. Buena parte de los autores más importantes y más destacados, son transversales y desarrollan temáticas trasversales. Nos sirven de ejemplo, especialmente, aquellos autores que articulan contenidos específicos con el área de las humanidades de suerte que no solo responden al porqué, para qué, cómo y dónde de la educación, sino, además, al con quién. John Dewey ha pensado en la filosofía, el arte, la educación y la psicología, Howard Gardner en la cognición, lo social y lo emocional. George Lakoff en el lenguaje, la política y la ética. Martha Nussbaum en la filosofía, la literatura, política y la ética social, Humberto Maturana en la ética social, la biología, la psicología y la educación. Antonio Damasio de la Neurobiología, la Psicología, la sociedad y la educación.

\subsubsection{Conexión emoción-razón}

Reivindicar el protagonismo de lo emocional en un mundo que se deshumaniza cada vez 
más por concepto de la mera razón resulta perentorio. Gestar la conexión emoción-razón es nuestro mayor interés. Defendidas las emociones como reacciones que la naturaleza ha ideado para garantizar la supervivencia, se hace necesario, por nuestro propio beneficio, aprender a escucharlas y gestionarlas (no ignorarlas o erradicarlas). La Neurociencia ha demostrado que las emociones mantienen la curiosidad, permiten recordar contenidos, nos sirven para comunicarnos y son imprescindibles en los procesos de razonamiento y toma de decisiones (Damasio). Si entendemos la educación como un proceso de aprendizaje para la vida, la educación emocional resulta indispensable porque contribuye al bienestar personal y social. En síntesis, los procesos emocionales y los procesos cognitivos (racionales) son inseparables, por lo que la educación debe actuar en su conexión y no lo contrario. Advertida la relevancia y las bondades educativas y sociales de la conexión emoción-razón, lo más justo con nosotros mismos sería sacar provecho de ella en lugar de intentar desconectar lo que por naturaleza está conectado.

\subsubsection{Multisensorialidad}

Conscientes de los efectos catárticos a que conlleva el arte, las nuevas exploraciones que aquí se proponen pretenden aprovechar su poder liberador sobre las emociones del hombre. Aunque la arquitectura, la escultura, la pintura, la declamación (poesía) y la danza hacen parte de las artes, nos interesa especialmente el teatro (como parte de la música) y el cine (artes totalizantes por excelencia) por su capacidad para recrear realidades y conectarse con las emociones humanas, en virtud de su multiplicidad sensitiva (audiovisual).

\subsection{Exploración 1: Cine}

El cine, permite adentrarse en problemas cotidianos sociales y culturales, y construir visiones en torno a acontecimientos pasados, presentes y futuros. Juzgar y ponernos en el papel de los personajes, favorecer la interlocución con valores, ideas, pensamientos, actitudes y normas, son otras de sus bondades. En la actualidad el cine actúa como educador informal transformándose en instrumento educativo por su capacidad de formar a través de la lúdica y la diversión. Son instrumentos de profundización y crítica. De acuerdo con Martha Nussbaum (1997), algunas películas tienen el potencial para realizar contribuciones similares a las que atribuye a la novela, es decir, que suscita emociones poderosas, desconcierta, intriga y conlleva la percepción cercana de las dificultades de los demás e inclusive, brinda placer en el acto del mismo enfrentamiento de los problemas y las dificultades de los demás, como si fueran nuestras. En síntesis, el cine (al igual que la literatura) nos constituye en jueces participativos.

Esta exploración se llevó a cabo en ambas asignaturas: Concepciones y Políticas de Infancia y Teorías cognitivas. En la Licenciatura en Pedagogía Infantil, durante la asignatura de Concepciones y Políticas de Infancia, se interactuó con películas como "Los colores de la montaña" y "La sociedad de los poetas muertos". Con la primera película, los estudiantes lograron sensibilizarse frente a la situación social que vive nuestro pais y que logra trasladarse a la educación. Propusieron soluciones como educar en la humanidad y lo social antes que en lo académico para fomentar no la tolerancia (por las connotaciones que le da Maturana como sentimientos reprimidos) sino en el respeto y valor por las diferencias, en la legitimación del 
otro (Maturana). En el segundo caso, profundizaron sus comprensiones con respecto a las prácticas pedagógicas y a la inclusión de la conexión emoción-razón en el acto educativo, de cara a los avances en materia de neurociencia (Damasio, LeDoux, Carretié). Con los estudiantes de la licenciatura en comunicación e informática educativa, durante la case de Teorías cognitivas, se interactuó con la película "Mi nombre es Khan" como herramienta de apertura al tema (niños con necesidades educativas especiales (NEEs) y sensibilizar frente a la pluralidad de los estudiantes. La película comparte la historia real de Khan, un niño musulmán que padece el síndrome de Asperger. Llamado también síndrome de la literalidad, por su imposibilidad de comprender metáforas e ironías, este síndrome dificulta la interacción social y la comunicación, toda vez que la pragmática linguística no cobra relevancia. Aunque no suelen presentar retardo mental ni retraso en el desarrollo del lenguaje, su literalidad y falta de "sentido común" les dificulta la adaptación a la vida social. Al hacerse adulto, Khan se casa y vive en los Estados Unidos pero el atentando del 11 de septiembre (ataque terrorista a las torres gemelas) aunado a su condición de persona con necesidades educativas especiales, le hacen vivir un verdadero infierno.

Esta película fué elegida por dos razones esenciales: por su larga duración (2 horas 40 minutos), que permitía continuar rastreando la percepción del tiempo desde el punto de vista emocional y por la cantidad de sentimientos y emociones (amor, ira, pasión, amistad, tolerancia, protección) que pasa por lo individual, familiar, educativo, cultural y social y obliga a tomar parte del asunto. El tiempo asignado para la clase de Teorías cognitivas es de 4 horas semanales, divididas en: dos horas el lunes y dos horas el jueves. Con solo dos horas para ver la película, fué necesario dividirla en las dos clases (lunes y jueves), el lunes se dió inicio a la película y fué necesario pararla a los 80 minutos porque los estudiantes debían desplazarse a otra clase. Al interrumpir y parar la escena, hubo un silencio ensordecedor, al prender las luces, se evidenciaron mejillas húmedas en la mayoría de las mujeres y ojos tristes en los hombres. Propusieron continuar con la película pero no era posible porque debían pasar a otra clase.

Era fácil percibir en los rostros de los estudiantes su comprensión de las diferencias (cognitivas y educativas) de los niños con NEEs y el papel activo de su "yo apreciador y juez" del que se ocupa Smith de acuerdo con el cual a través del don de la simpatía nos vemos a nosotros mismos como los demás nos ven. El alto grado de sensibilidad frente al rol de jueces participativos y la legitimación del otro en sus diferencias, invitaría a Nussbaum y a Maturana a hacer parte de ésta conversación, de la misma forma que lo haría Strawson cuando sustenta que a través de los sentimientos morales podemos superar el déficit motivacional de las éticas cognoscitivas. En síntesis, el arte (el cine) como herramienta pedagógica trasciende a otros fines en los que la conexión emoción-razón cobra protagonismo.

La siguiente clase, esperaba con ansiedad rastrear el grado de emocionalidad para continuar viendo la película. Al intentar buscar la escena en la que se había cortado la anterior clase, con sorpresa escuché frases en las que unos comentaban y otros se disculpaban por no haber esperado hasta ese día para terminar de ver la película. Todos los que asistieron ese día (25 de 31) decidieron terminar de ver la película en casa con sus familias y/o amigos, incluso algunos de ellos se dieron cita en la casa de un compañeros para verla a través de la internet. En esas 
circunstancias, se dió paso a la interacción libre en la que comentaron y formularon preguntas de manera voluntaria.

-¿Por qué algunas instituciones violan la ley de inclusión?

-¿Por qué los docentes de los salones regulares no están capacitados para atender a esta población que merece y necesita ser valorada?

-¿Cómo podemos ayudar a estos pequeños?

-¿Cuáles son los factores que influyen o aumentan los riesgos de padecer algún tipo de trastorno?

-¿Qué podemos hacer como integrantes de una sociedad y futuros maestros y/o padres de familia para identificar esta población y ayudarla?

-¿Cuáles son las políticas vigentes que protegen esta población?

-¿Existen otros tipos de necesidades educativas especiales? ¿cuáles? ¿cómo tratarlas? ¿cuáles son sus características?

-¿Qué actividades les permite avanzar y aprender mejor?

-¿Qué sucede en su cerebro?

Que el cine permita hechizar y hacer captar una imagen fuerte e impresionante de la realidad, que sea una extensión humana que no le anula como hombre ni lo desarraiga de su entorno cotidiano sino que lo potencia, de acuerdo con Joan Ferrés, se hace evidente cuando los estudiantes interactúan con películas que tocan sus fibras afectivas. Los estudiantes vivieron un proceso de auto-sensibilización que los movilizó a sentirse responsables de ésta población y creó la necesidad de formular interrogantes que les permitiera comprender las razones por las cuales Khan un niño con síndrome de Asperger, era tan diferente y especial sin embargo, ni la educación ni la sociedad estaban en capacidad para ayudarlo.

De esta forma, el tema sobre teorías cognitivas (formas de aprender, discurso pedagógico y estrategias metodológicas) en niños con necesidades educativas especiales, fué desarrollado asignando al estudiante el papel protagónico y tocando fibras afectivas que permiten legitimizar al otro en las diferencias a través del amor, como lo sostiene Maturana. Que los maestros respondan preguntas que los estudiantes no han formulado es uno de los aportes de Freire cuando hace una crítica de la educación repetitiva y bancaria. Cambiar la pedagogía de la respuesta por la pedagogía de la pregunta (Freire) fué la estrategia aplicada en este caso gracias a la sensibilidad y sentimientos morales (Strawson) que despierta el cine, de acuerdo con Nussbaum. Haber finalizado la película en casa con su familia y/o amigos, y no esperar hasta la siguiente clase, evidencia el fuerte componente motivacional de la actividad, por lo tanto, de acuerdo con Damasio, los estudiantes tendrían más oportunidades de recordar los 
contenidos, porque lo que nos motiva nos emociona y lo que nos emociona, lo recordamos más fácilmente.

En el cine la conexión emoción-razón se encuentra presente en cada escena, en la posibilidad de cada estudiante de asumir un rol protagónico especialmente en aquellas escenas que presentan más carga emocional. El cine es utilizado como herramienta eficaz para despertar y crear conciencia personal y social (Maturana) ante situaciones culturales, políticas y religiosas que atentan contra la dignidad humana. Como catalizador de la conciencia ética, fomenta la educación de las emociones, sensibiliza y provoca cambios de actitud en las personas ante estos problemas sociales (Nussbaum, 1997).

Esta exploración, rastreó el poder del cine, no solo para conectar la emoción con la razón, sino, además, para sensibilizar frente a las dificultades de los demás y asumir un papel activo (mediante la pregunta) y dinámico en la solución de los problemas de los demás como si fueran propios (Strawson y Nussbaum). De la misma forma que la publicidad promueve el consumismo desenfrenado con el uso de la emoción, los docentes deben convertirse en publicistas de la educación, de acuerdo con Pozo. En síntesis, lejos de perpetuar la educación racionalista basada en una antropología de estirpe platónica, el cine no deja de ser en buena parte de los casos una herramienta humanizante cuando mejora la atención, la comprensión, el aprendizaje y fomenta emociones que conecten con la razón, de la misma forma que lo hace el teatro. En síntesis, la presencia de maestros que reconozcan el acto de innegable impacto y alcance político de la conexión de la emoción con la razón, resulta determinante para avanzar en la cohesión social y la calidad educativa y quitarnos los vestigios de los moldes y paradigmas que nos momifican.

\subsection{Exploración 2: Teatro del oprimido - Teatro foro}

Al igual que la anterior, ésta exploración se llevó a cabo con estudiantes del programa de la Licenciatura en comunicación e informática educativa de tercer semestre, durante la asignatura de Teorías cognitivas. El teatro del oprimido es una estrategia que inició en lo social con la teoría del oprimido y la pedagogía de la autonomía del brasilero Paulo Freire y se trasladó al ámbito educativo por las múltiples coincidencias que los estudiantes y algunos pensadores como el también brasilero Augusto Boal identificó.

Por las características de la población (estudiantes de Licenciatura en Comunicación e Informática Educativa), de las seis modalidades propuestas por Augusto Boal (2000) para trabajar el Teatro del oprimido: Teatro periodístico, el Teatro legislativo, el Teatro invisible, el Arco iris del deseo, el Teatro imagen, el Teatro foro, solo se utilizará el Teatro foro o "espect -actor", de un lado, porque faculta la transformación del espectador en protagonista del problema, la situación opresora y construir soluciones viables que les permitan avanzar y los conduzca a la propia liberación y la de los demás, y del otro lado, porque hace posible que el estudiante o "espect-actor", entre en escena solo cuando se sienta preparado para hacerlo o lo estime conveniente.

Conscientes que la clave no estaría en el método, sino, en la puesta en escena, esta nueva exploración pretende construir un escenario en el que los estudiantes no solo hagan catarsis 
y pongan en escena las situaciones educativas que consideran opresoras, sino que, además, puedan reaccionar (acto perlocucionario) ante su propia situación opresora o la de los demás.

Atendiendo a las recomendaciones del fundador del Teatro del oprimido (Boal), los estudiantes y la docente se sientan en el piso, formando un círculo con una vela encendida en el centro como símbolo de esperanza. Junto a la vela había un objeto, si alguien lo tomaba voluntariamente, significaba que quería compartir la situación que lo oprimía, los demás podían reaccionar frente a esa situación o simplemente compartir la propia. Por ser estudiantes de sexto semestre y haber vivido recientemente (2014A) un paro, para no coartar las intervenciones y para evitar contradicciones (situaciones opresoras), no se tomaron fotos de la actividad, solo se grabó el audio. Todos los estudiantes participaron de la actividad. Sus intervenciones demuestran la desilusión, desagravio e impotencia frente al sistema educativo y social que están viviendo. Las intervenciones podrían resumirse en las siguientes expresiones:

"Nos dan la libertad pero nos dicen cuando usarla" "Los docentes ven una masa estudiantil homogénea, por lo tanto, recibimos una educación deshumanizante porque no valora las diferencias pero entrena para la competencia" "Siempre tenemos la fe puesta en algo, ¿por qué no hemos podido tenerla en la educación?". "A los niños se les está educando en conocimientos y no en la sensibilidad social". "La educación está asesinando la niñez". "Nos educan para ser competentes y productivos y no para ser felices y buenos seres humanos". "En general, cuando pienso en un docente lo imagino dándome la espalda, por eso, yo también se la doy”. "Las estrategias pedagógicas como los programas y los mapas conceptuales, hacen que perdamos nuestra capacidad de asombro". "Somos arlequines de la educación". "El consumismo es una estrategia del sistema para mantenernos ocupados y no hacer resistencia a la baja calidad de la educación que recibimos". "Nos enmascaran porque nos preparan para estar pendientes del qué dirán (acrecentando el consumismo desenfrenado)". "La educación atiende a las necesidades de la economía, no de los estudiantes y la sociedad, por lo tanto, se educa para la economía; no para la humanidad". "No es que la mayoría de los docentes sean malos, sino perversos". "Por qué la evaluación docente es obligatoria si los resultados no son de obligatorio cumplimiento?”.

Si las percepciones de los estudiantes ya han sido vislumbradas y comprendidas por muchos pensadores, ya desde la sociología (Bauman y Lipovetsky), ya desde la filosofía (Strawson, Smith, Maturana y Nussbaum), ya desde la neurociencia (Ledoux, MacLean, Damasio y Carretié), ¿por qué la academia que debería ser la más interesada continúa ignorándolas?

Dentro de las soluciones propuestas por los estudiantes a las situaciones que identificaron como opresoras, mencionaron:

Educar en valores y humanidad antes que en contenidos y para el trabajo. Si nos educan en las diferencias y en la humanidad, podremos actuar sin estar vigilados, porque nos portamos bien por convicción propia. Que la academia comprenda que no pueden educarnos de la misma forma como fueron educados simplemente porque somos diferentes. Aunque todos seamos jóvenes, nuestras necesidades, capacidades 
e intereses son distintos, por lo tanto deben educar en las diferencias aunque les sea más difícil. Los niños deben ser educados en la armonía, la felicidad antes que para los números y las letras. Que la evaluación docente se haga efectiva. Debemos decir "no" a las marcas y al consumismo en general, vestirnos con trajes sin marcas (Nike, Adidas, Puma...), de lo contrario, continuaremos siendo sus modelos gratis. Los docentes que no permiten al estudiante interactuar, no es maestro, es un ingeniero que cree estar programando trabajar Robots.

Que los estudiantes reclamen calidad educativa y humanizante y señalen la academia como la celestina de la desigualdad social, se hace evidente cuando expresan "La educación atiende a las necesidades de la economía, no de los estudiantes y la sociedad, por lo tanto, se educa para la economía; no para la humanidad". Que la modernidad no pueda vivir sin una gran dosis de violencia, de acuerdo con Bauman (2002), especialmente porque no puede responder a las necesidades de los jóvenes, haría de la educación el espacio propicio para frenar la disgregación social. La transformación racional del mundo humano no ha sido suficiente para contener y erradicar la barbarie y reclama con urgencia su conexión con la emoción, no solo en el ámbito social, sino, además, en el acto educativo. Lejos de oprimir y uniformar con un Método con mayúscula como lo pretendía Comenio en la Didáctica Magna, esta práctica liberadora permite a los estudiantes expulsar sus opresiones y proponer otras soluciones que amplían los dominios de la justicia convirtiéndolos en actores participativos que legitiman a la otro mientras cambian su lenguajear (Maturana). Las emociones, lejos de ser sentimientos o fenómenos de ignorancia que dependen de la moral, como lo sostuvo Aristóteles (2005), son el elemento más importante porque desinhibe, encanta y atrae la atención de los estudiantes, para que la razón no solo diga, sino que haga en conexión con la emoción (Austin, 1996). Si los diversos estudios han mostrado que los estímulos emocionales tienden a ser mejor recordados que los estímulos neutros de acuerdo con Carretié, el teatro, así como también lo verificamos en el caso del cine, es una herramienta que favorece los estímulos positivos y la conexión de la emoción con la razón.

El Teatro del oprimido ofrece espacios vivos para la conexión emoción-razón desde la catarsis de los estudiantes sobre las situaciones que los oprimen hasta las soluciones que proponen por considerarlas viables y justas para sí mismo y para los demás. La ira, la desilusión, la impotencia y la inconformidad son emociones especialmente presentes en esta exploración. Con el Teatro foro no es necesario solicitar la atención de los estudiantes porque permite su participación y comparte la responsabilidad de su propio proceso de aprendizaje y las posibles soluciones a situaciones que nos competen a todos.

Tanto el cine como el Teatro del oprimido, fueron transitados y acompañados de principio a fin por las exploraciones transversalizadoras (la interactividad, la perlocutividad, la transversalidad, la conexión emoción-razón y la multisensorialidad) por sus múltiples bondades para sensibilizar, movilizar pensamiento, dar claridad, emocionar y motivar. El cine, el Teatro del oprimido y las exploraciones transversalizadoras permiten conectar la emoción con la razón favoreciendo la Metacognición de los estudiantes sobre sus propios sentimientos y emociones. Hablar de los sentimientos, nombrarlos, comprenderlos y comunicarlos, aunque 
no resulta tarea fácil, sí es un deber educativo y condición necesaria para trascender el racionalismo del que somos presos.

\subsection{Encuesta}

Para poner a prueba las exploraciones adelantadas (el cine, el Teatro del oprimido y las exploraciones transversalizadoras), se aplicaron dos encuestas: la encuesta A al iniciar el proceso de investigación (semestre A de 2012), y la encuesta B al finalizar el proceso (semestre A de 2014). Ambas encuestas se estructuraron de acuerdo al Formulario Base del proyecto de culturas urbanas en América Latina y España desde sus imaginarios sociales propuesta por Armando Silva porque permite la adaptación para los fines que perseguimos. Las preguntas están organizadas de acuerdo a las siguientes áreas y categorías.

Figura 15. Clasificación de áreas y categorías

\begin{tabular}{|c|c|}
\hline Área & Categoría \\
\hline $\begin{array}{c}\text { CIUDAD } \\
\text { (Representada por la nueva universidad) }\end{array}$ & $\begin{array}{l}\text { CALIFICACIONES UNIVERSITARIAS } \\
\text { Percepción de los estudiantes frente a la nueva vida } \\
\text { universitaria. }\end{array}$ \\
\hline \multirow[b]{2}{*}{$\begin{array}{c}\text { CIUDADANOS } \\
\text { (Representada por los estudiantes) }\end{array}$} & $\begin{array}{l}\text { TEMPORALIDADES UNIVERSITARIAS } \\
\text { Qué tan rápido pasa el tiempo cuando están en las } \\
\text { diferentes clases (entre más motivación y conexión emo- } \\
\text { ción-razón, menos percepción del tiempo y viceversa). }\end{array}$ \\
\hline & $\begin{array}{l}\text { MARCAS UNIVERISTARIASLas formas de percibir las } \\
\text { clases y la interacción con los docentes en términos de: } \\
\text { Monotonía, normal, emocionante y divertida. }\end{array}$ \\
\hline
\end{tabular}

Se aclara que a los dos grupos les fué aplicada la misma encuesta pero preguntando por las percepciones en diferentes asignaturas, los siguientes formatos corresponden a las encuestas A y B. 
Figura 16. Formato de la encuesta A

\section{FORMULARIO BASE}

(Adaptación del formulario base de Armando Silva en: Imaginarios Urbanos)

Le pedimos responder la encuesta de manera espontánea. Esta encuesta sólo aspira a comprender modos de percepción universitaria. Gracias.

\section{IDENTIFICACIÓN}

Fecha:

Programa:

Semestre:

Edad: $\quad 15-20$ años____ 21 a 25 años____ más de 26 años

\section{CIUDAD}

\section{CALIFICACIONES UNIVERSITARIAS}

1. ¿Cómo percibe su universidad? (marque las opciones que desee)

Monótona

emocionante alegre

agotada vital

excluyente

1. ¿Qué es lo que más le gusta de la universidad (UTP)?

\section{CIUDADANOS}

\section{TEMPORALIDADES UNIVERSITARIAS}

1. Cuando está en otras clases diferentes a "Concepciones y Politicas de Infancia", siente que las clases son:

Cortas

normales

largas

muy largas

1. Cuando está en clase de "Concepciones y Políticas de Infancia", siente que la clase es:

Corta

normal

larga

muy larga 


\section{MARCAS UNIVERISTARIAS}

1. La mejor palabra para describir otras clases diferentes a "Concepciones y Políticas de Infancia" es :

Monotonía

normal emocionante y divertida

1. La mejor palabra para describir la clase de "Concepciones y Politicas de Infancia" es :

Monotonía

normal emocionante y divertida

1. Califique de 1 a 5 sin nombrarla, la asignatura que más les gusta y le permite avanzar en su proceso de aprendizaje.

1.

2.

3.

4.

5.

1. Califique de 1 a 5 la asignatura "Concepciones y Politicas de Infancia".

1.

2.

3.

4.

5.

1. Califique de 1 a 5 las actividades que más le emocionan Conversatorio clase tradicional Trabajo individual trabajo colectivo

1. Encuentra diferencias entre las prácticas pedagógicas de "Concepciones y Politicas de Infancia" y las demás? ¿cuáles? 


\subsection{Encuesta A. Generalidades}

Se aplicó al iniciar el proceso de investigación (semestre A de 2012) a estudiantes de primer semestre de la Licenciatura en Pedagogía Infantil, durante la clase de Concepciones y Políticas de Infancia. El objetivo fundamental de esta encuesta fué comparar las percepciones de los estudiantes con respecto a la nueva vida universitaria y a la motivación en cada una de las asignaturas. Se eligió esta técnica con esta población dado que aún no tienen vínculos afectivos con docentes que pudieran contaminar las respuestas de los estudiantes. Los datos obtenidos por esta encuesta, los avances teóricos de los seminarios del doctorado y las lecturas y conversaciones con el asesor, orientaron las tres exploraciones finales (el cine, el teatro y la conexión emoción-razón como exploración trasversalizadora) y la encuesta B.

La encuesta es utilizada como instrumento investigativo porque permite rastrear las percepciones de los estudiantes desde varios frentes (académico, emocional y social). Al tabular los resultados de la encuesta se pudo evidenciar que algunas de las presunciones o hipótesis mencionadas presentaban fundamento real que decidimos someter a prueba por medio de las exploraciones (cine y teatro), algunas de ellas son las siguientes:

La ubicuidad de la emoción, emociones positivas y negativas, prácticas liberadoras y participativas que conecten emoción con la razón, a través del cine y el teatro se puede contrarrestar el déficit motivacional de las éticas cognoscitivas, la educación universitaria no solo debe ser profesionalizante, sino, además, humanizante, la competencia humana en detrimento del otro, no es natural, es cultural, educar en el amor para la convivencia humana sería la clave.

La encuesta se aplicó a 29 estudiantes de primer semestre de la Licenciatura en Pedagogía Infantil, durante la asignatura Concepciones y Políticas de Infancia. Esta encuesta rastrea la percepción de los estudiantes sobre la nueva vida universitaria, el tiempo (no solo el tiempo del reloj, sino, especialmente, el tiempo del hombre) y las prácticas pedagógicas. Para evitar represiones (Paulo Freire) y favorecer las respuestas sinceras, la encuesta no pregunta por información personal (nombre o género), sino, por el programa, el semestre y la edad.

La encuesta contiene 10 preguntas: 8 cerradas y 2 abiertas. Las dos primeras preguntan por la forma como perciben la universidad y qué es lo que más le gusta de ella. Las preguntas 3 y 4, se ocupan de la percepción del tiempo con respecto a las clases (a clases más interactivas, motivadoras y emocionantes menor sensación del tiempo). Las últimas 6 preguntas (5 a la 10), permiten la constatación (casi anónima) de las asignaturas y las interacciones y motivaciones que éstas suscitan. Durante las clases de Concepciones y Políticas de Infancia, solo se puso en escena la exploración que favorece la interacción. Aplicada la encuesta y tabulados los resultados, las demás exploraciones (cine y teatro), buscaban a través de la conexión emociónrazón, suplir algunas de las deficiencias señaladas por los estudiantes. Los resultados de la encuesta fueron los siguientes: 


\subsubsection{Análisis de los resultados (encuesta A)}

Figura 17. Pregunta 1. ¿Cómo percibe su universidad?
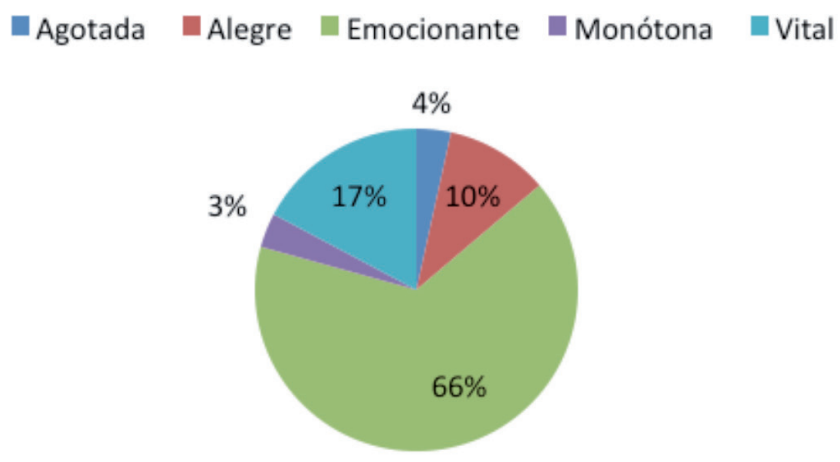

Con la pregunta número 1, que interroga por las percepciones sobre la universidad, se logra evidenciar que los estudiantes en la mayoría de los casos, encuentran la universidad como emocionante (66\%), vital (17\%) y alegre (10\%). Si los estudiantes en primer semestre encuentran emociones en la vida universitaria, ¿qué metamorfosis sufre esa motivación y energía positiva hasta convertirse en desmotivación?

Rendir culto a los estímulos y respuestas como lo sugería Skinner, o al protagonismo de la pedagogía de la respuesta y no la de la pregunta que critica Freire, la academia lejos de fomentar la interacción y abrir espacio a sus pre saberes, los convierte en espectadores pasivos de acuerdo con Boal.

De la motivación, expectativa y opciones de futuro que vislumbran los estudiantes al ingresar a la vida universitaria, dan cuenta las respuestas a la pregunta número 2.

Figura 18. Pregunta 2. ¿Qué es lo que más le gusta de la Universidad Tecnológica de Pereira?

Oportunidades $\quad$ Calidad educativa $\quad$ El ambiente y la gente

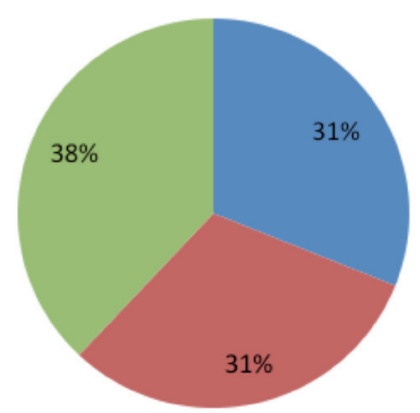

Fuente: la autora 
De acuerdo con la pregunta 1, el 93\% de los estudiantes perciben la universidad como alegre, emocionante y vital, y el 100\% la advierten como un lugar con gente amable y un ambiente agradable que ofrece oportunidades y calidad educativa. La encuesta fue aplicada en el marco de la asignatura "Concepciones y Políticas de Infancia" con una intensidad de cuatro horas semanales, los días martes de 8:00 am a 12:00. Mantener la atención, la concentración y el interés durante 4 horas continuas en una asignatura que es $100 \%$ teórica, representó un reto. La interacción permitió a los estudiantes intercambiar sentires, saberes y sentar una posición crítica frente a las Concepciones y Políticas de Infancia de los últimos 70 años y proponer otras políticas de cara a las actuales necesidades educativas, culturales y sociales de los pequeños. Enmarcada en el área Ciudadanos, categoría Temporalidades Universitarias, esta exploración, reconoce el tiempo del hombre a diferencia del tiempo del reloj (no es lo mismo una hora de conflictos a una hora de amor) como una medida subjetiva directamente relacionada con la motivación, en este caso, de los estudiantes.

Las preguntas 3 y 4 interrogan por la apreciación del tiempo durante la clase de Concepciones y Políticas de Infancia y las demás clases (sin especificar nombres por respeto y calidad de la información).

Figura 19. Pregunta 3. Cuando está en otras clases diferentes a "Concepciones y Políticas de Infancia”, siente que las clases son: Cortas, normales, largas o muy largas

\section{- Largas $\quad$ Normales}

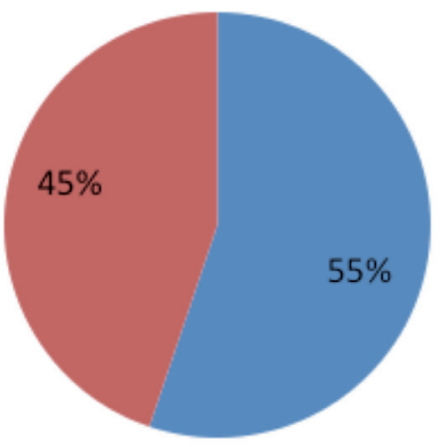

Fuente: la autora

La percepción del tiempo mientras asisten a otras asignaturas sería un 10\%, inferior con respecto a Concepciones y Políticas de Infancia, lo que para algunos podría ser poco significativo, sin embargo, al formular la pregunta número 4 que interroga directamente por la apreciación del tiempo cuando se encuentran en la asignatura Concepciones y Políticas de Infancia, la diferencia cobra protagonismo. 
Figura 20. Pregunta 4. Cuando está en clase de “Concepciones y Políticas de Infancia”, siente que la clase es: Corta, normal, larga o muy larga.

normal Corta

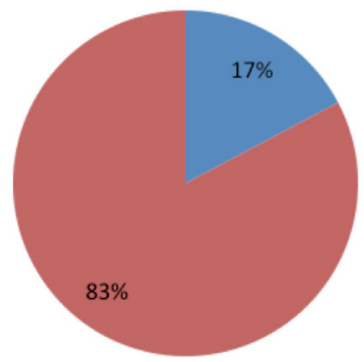

Fuente: la autora

Mientras Comenio uniforma no solo el pensamiento, sino, además, el conocimiento y propone un Método con mayúscula, que funcione para todos, es decir, que enseñe todo a todos como Pansofía, Dewey sostiene la necesidad de orientar el acto educativo a través del arte, que da cuenta de la diversidad humana y formas de concebir el mundo. Que el 83\% de los estudiantes perciban el tiempo más corto durante las clases de Concepciones y Políticas de Infancia, a pesar de recibirla durante 4 horas continuas, todas ellas teóricas, permite evidenciar el poder de la interacción para aumentar los niveles de motivación (y memoria de acuerdo con Damasio) y recortar el tiempo inclusive. Si la clave no está en dictar buenas clases, sino, interacciones ricas, resulta determinante que la academia actúe en consecuencia.

El mismo fenómeno parece presentarse en las respuestas a las preguntas 5 y 6 que buscan enmarcar las otras asignaturas y Concepciones y Políticas de Infancia en una sola palabra. Para mejor comprensión y exploración se muestran de manera simultánea.

Figura 21. Pregunta 5. La mejor palabra o expresión para describir clases diferentes a Concepciones y Políticas de Infancia es:

Monótonas $\quad$ Normal Emocionantes y divertidas

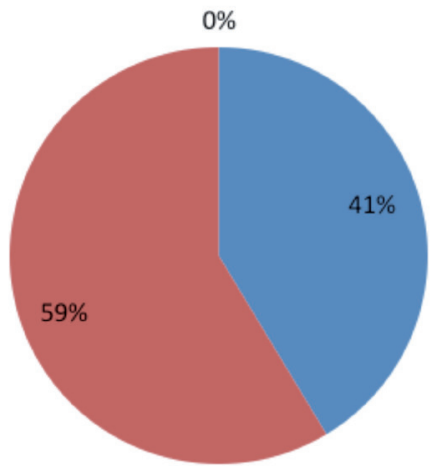


Figura 22. Pregunta 6. La mejor palabra o expresión para describir clases de Concepciones y Políticas de Infancia es:
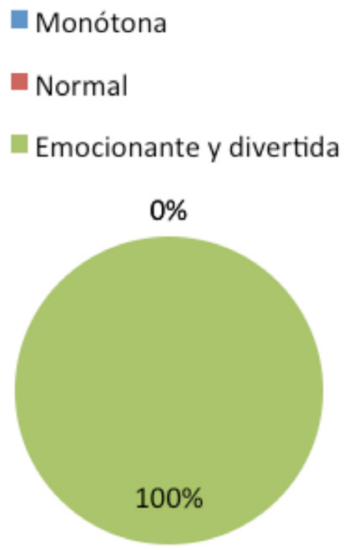

Fuente: la autora

Con la pregunta 5 se evidencia que las demás asignaturas son percibidas como "normales" con respecto a Concepciones y Políticas de Infancia, sin embargo, nadie las señala como emocionantes y divertidas, dejando en evidencia que la academia está especialmente habitada por agelastos, inclusive desde los primeros semestres en los que los estudiantes ingresan con la falsa esperanza de encontrar una educación diferente. Que los docentes no proporcionen espacios interactivos como escenario de encuentro de sus emociones, percepciones y motivaciones, especialmente en una Licenciatura (en Pedagogía Infantil) en la que se forman profesionales para atender la población infantil, profundiza el déficit motivacional de las éticas cognoscitivas.

Si únicamente nos motiva lo que nos emociona, si de la emoción depende la motivación y sin motivación no hay memoria, de acuerdo con Damasio, ¿qué clase de educación se está brindando a los pedagogos infantiles y a los que serán sus futuros estudiantes toda vez que están siendo educados por fuera de la interacción, la motivación y la emoción? Resulta determinante un giro que lejos de perpetuar desconexiones (Platón), taxonomías (Aristóteles), una forma de comportarse de acuerdo a los estímulos (Skinner) y prácticas pedagógicas desuetas (Comenio), inviten a los nuevos docentes infantiles a ejercer prácticas innovadoras que conecten la emoción con la razón y eviten caer en la catástrofe a la que conlleva reprimir la emoción infantil, entre otros, de los que habla Martha Nussbaum "la represión de la emoción infantil (...) puede lograr que las emociones retornen de manera más destructiva, genuinamente irracional" (Nussbaum, 1997, p. 104). Generar climas interactivos y emocionalmente positivos que faciliten el aprendizaje y la seguridad de los estudiantes resulta determinante.

Las respuestas a la pregunta 6 son contundentes el 100\% de los estudiantes describen la clase de Concepciones y Políticas de Infancia como aquella que les permite aprender de una forma más fácil, emocionante y divertida. Las siguientes imágenes así lo evidencian 
Figura 23. Estudiantes de Concepciones y Políticas de Infancia desarrollando actividades que incluyen las exploraciones trasversales
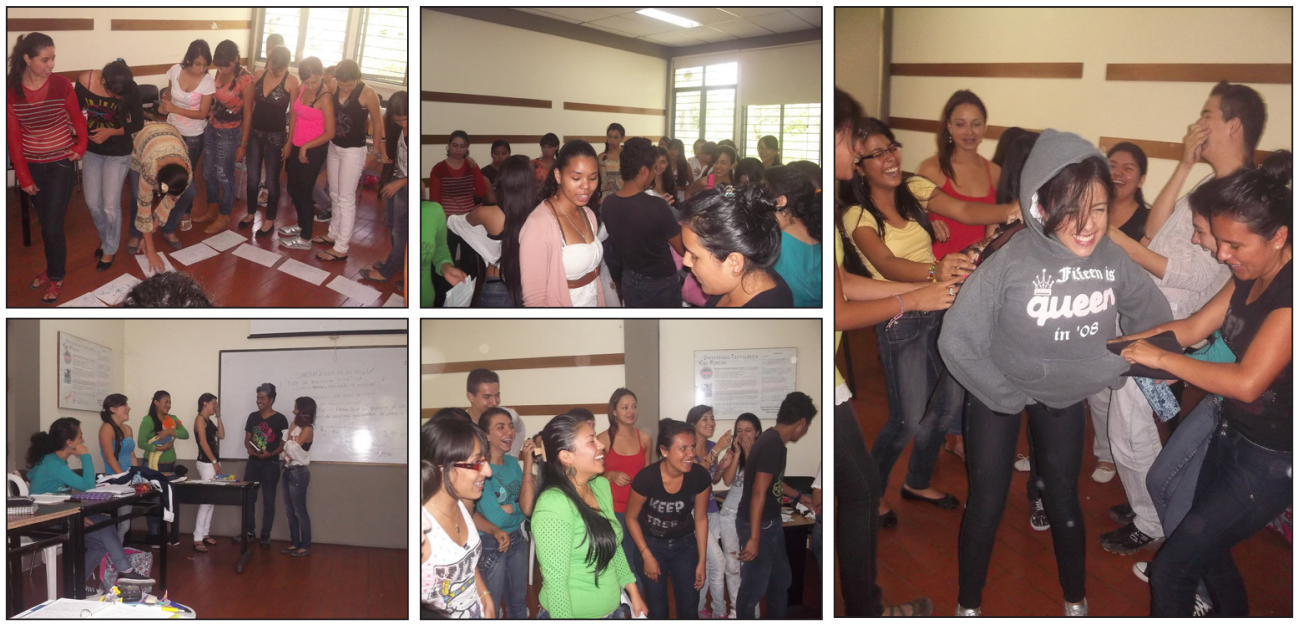

Fuente: la autora

Para confirmar las respuestas anteriores en las que la asignatura de Concepciones y Políticas de Infancia no solo es la que trascurre más rápido (percepción de tiempo recortado aunque su duración en igual o mayor a las demás asignaturas), sino, además, la más emocionante y divertida, se formularon las preguntas 7 y 8 que permiten la calificación numérica de la asignatura que más les permite avanzar (pregunta 7) y específicamente la de Concepciones y Políticas de Infancia pregunta 8). Para su mejor comprensión y exploración se muestran de manera simultánea.

Figura 24. Pregunta 7. Califique de 1 a 5 sin nombrarla la asignatura que más le permite avanzar en su proceso de aprendizaje

Cuatro $\quad$ Cinco

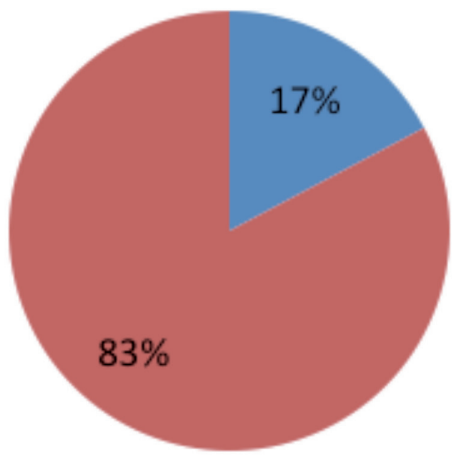

Fuente: la autora 
Figura 25. Pregunta 8. Califique de 1 a 5 la asignatura "Concepciones y Políticas de Infancia”
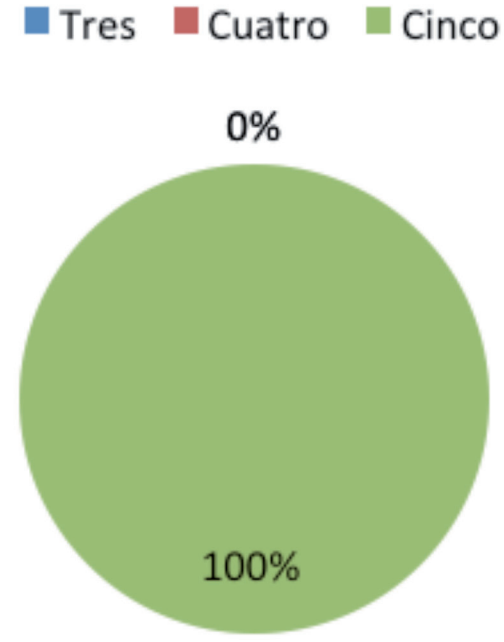

Fuente: la autora

En el primer caso (pregunta 7), el 83\% de los encuestados asignó el máximo puntaje (5 puntos) a la asignatura que más gusta y le permite avanzar en su proceso de formación, el otro 17\% de los encuestados le asignó 4 puntos. De acuerdo a los datos recolectados por medio de las anteriores preguntas, podría deducirse que esa asignatura calificada con los dos puntajes más altos ( 4 y 5 ) es Concepciones y Políticas de Infancia. Para poner a prueba las sospechas, en el segundo caso (pregunta 8) se solicitó calificar de 1 a 5 específicamente la asignatura Concepciones y Políticas de Infancia, obteniendo que el 100\% de los estudiantes le dan la mayor cantidad de puntos a esta materia. Estos resultados no solo confirman todas las suposiciones hechas hasta aquí, sino, además, que las clases ricas en interacción, les proporciona un ambiente cómodo y seguro, los hace felices y les permite avanzar en su proceso de aprendizaje a través de la motivación que alarga la vida de la memoria, si nos atenemos a Damasio.

Corroboradas las sospechas, fué necesario adentrarnos un poco más en los datos e identificar entre la variedad de actividades desarrolladas durante las clases de Concepciones y Políticas de Infancia, cuales les emocionaban más. Es así como aparece la necesidad de formular la pregunta 9. 
Figura 26. Pregunta 9. Califique de 1 a 5 las actividades que más le emocionan. Conversatorio clase tradicional, trabajo individual o trabajo colectivo

- Conversatorio $\square$ Trabajo individual $\square$ Clase tradicional $\quad$ Trabajo colectivo

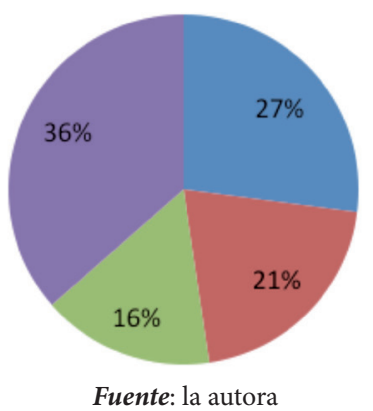

Las actividades que requieren de un rol activo e interactivo del estudiante obtuvieron el $84 \%$ y son: trabajo colectivo (36\%), conversatorio (27\%) y trabajo individual (21\%). Solo el $16 \%$ prefieren la clase tradicional. Estos resultados hacen evidente los deseos de los estudiantes de ser actores vivos en su propio proceso de aprendizaje, dejando en entredicho teorías de antaño que dan centralidad a la mera racionalidad instrumental y defienden la relación unilateral en la que el docente lo sabe todo y el estudiante se limita a la categoría de "tabula rasa" una hoja en blanco, apta para que el docente escriba sobre ella (Locke). Que la educación repetitiva y bancaria (Freire) disfraza cuando no ignora las necesidades actuales de los estudiantes, se hace evidente con el porcentaje (84\%) evidenciado mediante esta pregunta a la importancia que los estudiantes asignan a la interacción bilateral entre estudiante-docente.

Finalmente, la última pregunta de la encuesta (la pregunta 10), permite a cada estudiante, expresar con sus propias palabras las diferencias que encuentra específicamente entre las "prácticas pedagógicas" de la asignatura Concepciones y Políticas de Infancia y las demás asignaturas. Las respuestas podrían resumirse en las siguientes expresiones:

"Concepciones y Políticas de Infancia es una materia agradable ya que la profesora hace que sea agradable y que aprendamos mucho y crezcamos personal y profesionalmente a diferencia de otras asignaturas y otros profesores que no ayudan a los estudiantes". "En Concepciones y Políticas de Infancia se aprende de manera divertida y pues en otras es muy metódico". "Concepciones y Políticas de Infancia es diferente a las demás ya que la profesora da la clase de una manera más alegre". "Que las demás no enriquecen tanto, en Concepciones y Políticas de Infancia el aprendizaje se hace más fácil, entiendo más rápido". "En las demás clases no nos divertimos tanto ni entendemos tan claramente". "CPI es más divertida y se ha aprendido más, las otras son muy monótonas". "En Concepciones y Políticas de Infancia la metodología, las actividades extraclase, incluso las evaluaciones son divertidas. Gracias profe". "Aprender en Concepciones y Políticas de Infancia es mucho más fácil, se nota el amor por sus clases a diferencia de otros profesores". "Con los 
demás profesores no podemos expresar lo que pensamos, nos da miedo participar”.

Con palabras y expresiones como: alegre, agradable, se aprende más fácil, nos divertimos, entendemos más fácil, se hace evidente la eficacia de la interacción como escenario propicio para la conexión emoción- razón. Lejos de subordinar la educación a la política evitando la innovación y satanizando la risa y la alegría como lo hiciera Platón, la interacción trabajada en Concepciones y Políticas de Infancia de un lado, y las dos exploraciones (cine y teatro) que proponemos más adelante, del otro lado, aprovechan la plasticidad cerebral y los últimos avances sobre el funcionamiento cerebral para enseñar y aprender mejor, de cara a la sociedad actual que parece gobernada por el consumismo (Lipovetsky, 2003) y la liquidez (Bauman, 2002).

Rastreadas las inconformidades de los estudiantes con respecto a los discursos y prácticas pedagógicas de las demás asignaturas (a través de la encuesta A), fué necesario ampliar la población con la cual se estaba haciendo este rastreo, con el fin de corroborar si la percepción de los estudiantes en primer semestre de Licenciatura en Pedagogía Infantil coincidía con las percepciones de estudiantes de otro semestre y otro programa. El objetivo en este caso es rastrear las percepciones de los estudiantes sobre las prácticas pedagógicas de los docentes, el impacto de las exploraciones transversalizadoras y las situaciones que incrementaban su inconformidad en la vida universitaria. Si no todos los estudiantes son iguales, ni los contextos ni sus necesidades, resulta determinante la presencia de maestros que conecten de diferentes formas, pero que no tengan una cartilla, no solo porque ignorarían las diferencias ya mencionadas, sino, además, porque caerían en la uniformidad y el dogmatismo imposibilitando la conexión de la emoción con la razón.

Ya se ha mencionado a través de todo el documento la urgencia de repensar y renunciar a las taxonomías y al pensamiento metafísico que en complicidad con la dialéctica platónica y la lógica aristotélica, haría de la educación actual la materia prima que asegura la supervivencia de la desconexión emoción- razón.

Si el cine al igual que a la literatura, es una herramienta eficaz para educar en ciudadanía democrática y despertar la humanidad y las emociones con fines eudaimonísticos de acuerdo con Martha Nussbaum. El teatro es el escenario propicio para la catarsis (al igual que la tragedia griega) y proponer soluciones a las situaciones opresoras, de acuerdo con Augusto Boal. En consecuencia, el cine y el teatro son las exploraciones elegidas para hacer el mencionado rastreo por el fuerte componente emocional que proporcionan y despiertan. La conexión emociónrazón, es la exploración que por sus características omnipresentes y las bondades rastreadas en los anteriores capítulos (especialmente 2 y 3), permeará las dos exploraciones (cine y teatro).

\subsection{Encuesta B. Generalidades}

Aplicada a estudiantes de la Licenciatura en Comunicación e Informática Educativa, durante la asignatura de Evaluación del Aprendizaje, semestre 4. Es necesario aclarar que los estudiantes a quienes les fue aplicada la encuesta $B$, aunque son estudiantes de la asignatura evaluación de 
aprendizaje (semestre B-2014), realmente se está evaluando el impacto que tuvieron las nuevas exploraciones el semestre anterior durante la asignatura de Teorías cognitivas (A-2014). No se aplicó la encuesta al terminar la asignatura de Teorías cognitivas para ganar distancia y evitar que los estudiantes pudieran estar sesgados por el proceso de evaluación en curso.

En esas condiciones solo diligenciaron la encuesta aquellos estudiantes que vivieron el proceso de las nuevas exploraciones: el cine, el teatro del oprimido y las exploraciones transversales (la interactividad, la perlocutividad, la transversalidad, la conexión emoción-razón y la multisensorialidad).

Las encuestas A y B poseen la misma estructura, interrogantes y número de preguntas. La encuesta $\mathrm{A}$ interroga por las primeras percepciones de los estudiantes que ingresan a la vida universitaria (estudiantes se semestre 1) y la percepción de las prácticas pedagógicas a través del cine y las exploraciones transversalizadoras. La encuesta B pretendió rastrear la metamorfosis (semestre 4) de esas percepciones de los estudiantes con respecto a la vida universitaria y el impacto del cine, el teatro de oprimido y las exploraciones transversalizadoras en la asignatura.

\subsubsection{Análisis de los resultados (encuesta B)}

Figura 27. Pregunta 1. ¿Cómo percibe su universidad?

Alegre Emocionante Monótona $\quad$ Vital

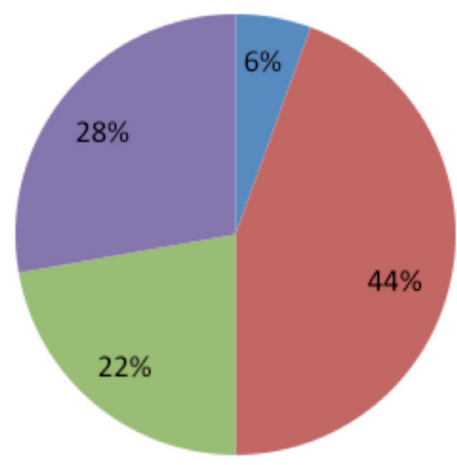

Fuente: la autora

Aunque la mayor parte de los estudiantes continúan percibiendo la universidad especialmente emocionante (44\%) y vital, el 22\% la aprecia monótona y solo el 6\% alegre. ¿Por qué la alegría se ha convertido en un invitado fantasma en el plano educativo? ¿continuamos rindiendo culto al pensamiento platónico en el que la emoción es desterrada como lo fueron los poetas de la Polis Ideal? ¿por qué en general la academia no ha logrado comprender los avances en materia de neurociencia que dan cuenta de la supremacía de la emoción sobre la razón y de las bondades de su conexión con la razón? 
Figura 28. Pregunta 2. ¿Qué es lo que más le gusta de la Universidad Tecnológica de Pereira?
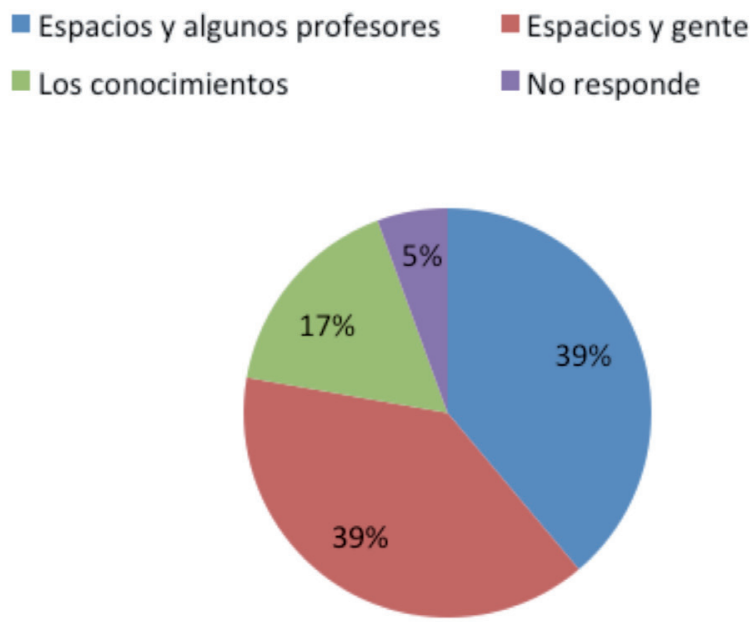

Fuente: la autora

Afortunadamente, la universidad continúa siendo para los estudiantes uno de sus lugares favoritos, no solo por sus espacios y docentes, sino, además, por la gente y los conocimientos que allí encuentran. Estos datos dan cuenta del protagonismo de la vida universitaria en los estudiantes, la misma que debería percibirse como una oportunidad para ganar terreno (Pozo) frente al consumismo desproporcionado (Lipovetsky) y trabajar en la legitimación del otro (Maturana) bajando los niveles no solo de la mortalidad académica, sino, además del déficit motivacional de las éticas cognoscitivas.

Figura 29. Pregunta 3. Cuando está en otras clases diferentes a "Evaluación del aprendizaje", siente que las clases son: cortas, normales, largas o muy largas

largas muy largas normales

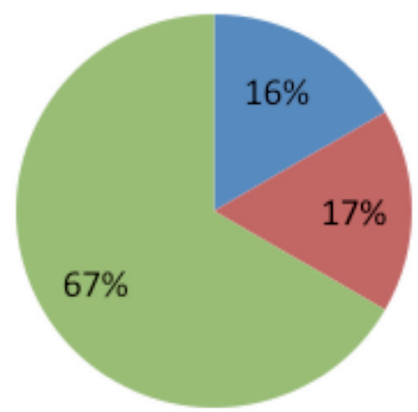

Fuente: la autora 
Aunque el $67 \%$ de los estudiantes perciben las demás asignaturas como "normales", con respecto a Evaluación del aprendizaje (Teorías cognitivas), ninguno las identifica como cortas. Las respuestas a la pregunta 4, permite evidenciar la eficacia de las exploraciones transversales. A pesar de haber pasado un semestre desde que se desarrollaron las exploraciones transversalizadoras durante la asignatura de Teorías cognitivas, los estudiantes aún recuerdan las interacciones y le asignan el primer lugar.

Figura 30. Pregunta 4. Cuando está en clase de "Evaluación del aprendizaje", siente que la clase es: corta, normal, larga o muy larga.

normal $\quad$ Corta

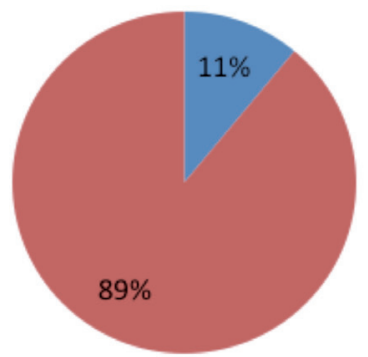

Fuente: la autora

Mientras en la pregunta 3 el 37\% de los estudiantes señalan la percepción del tiempo en otras asignaturas como "normal", las respuestas a la pregunta 4, permiten comprender que el $89 \%$ de los encuestados perciben la asignatura de Evaluación del Aprendizaje como corta, solo el 11\% la percibe "normal" posiblemente son los estudiantes que el semestre pasado no interactuaron con las exploraciones transversalizadoras (durante las clases de Teorías cognitivas) porque estuvieron con otros docentes. Estos resultados demuestran que la emoción y la razón funcionan de manera articulada, como lo sostienen los trabajos de MacLean y Damasio; no obstante, la razón sin la emoción es una vieja pretensión de los filósofos y la emoción sin la razón un reciente descubrimiento de LeDoux y Carretié.

Figura 31. Pregunta 5. La mejor palabra para describir otras clases diferentes a "Evaluación del Aprendizaje" es:

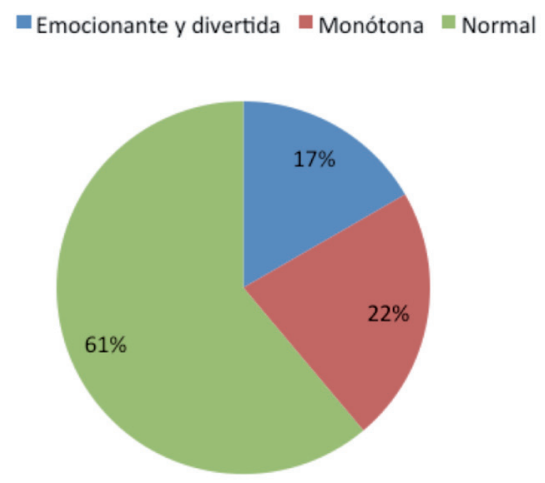

Fuente: la autora 
Figura 32. Pregunta 6. La mejor palabra para describir la clase de "Evaluación del Aprendizaje" es:

Emocionante y divertida $\quad$ Normal

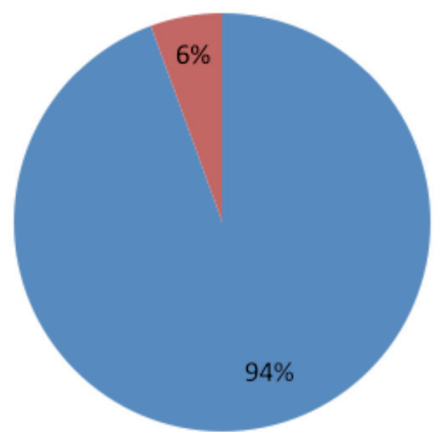

Fuente: la autora

Al contrastar estos dos gráficos, podemos aducir que aunque la mayoría de los estudiantes (61\%) percibe otras asignaturas como "normales", solo el 17\% las siente como emocionantes y divertidas, mientras que Evaluación del aprendizaje es, de acuerdo con la encuesta la asignatura que más perciben como emocionante y divertida, en ningún caso le asignan la categoría de "normal", dejando evidenciar la eficacia de la exploración transversal conexión emoción-razón y la exploración que favorece la interacción en el proceso educativo.

Figura 33. Pregunta 7. Califique de 1 a 5 sin nombrarla, la asignatura que más le gusta y le permite avanzar en su proceso de aprendizaje

- Cuatro Dos Cinco $^{-}$

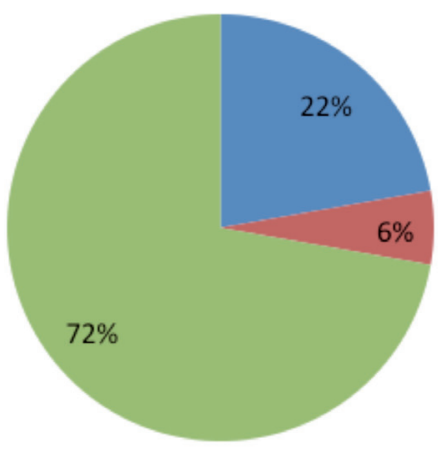

Fuente: la autora 
Figura 34. Pregunta 8. Califique de 1 a 5 la asignatura "Evaluación del aprendizaje"

- Cuatro $\|_{\text {Cinco }}$

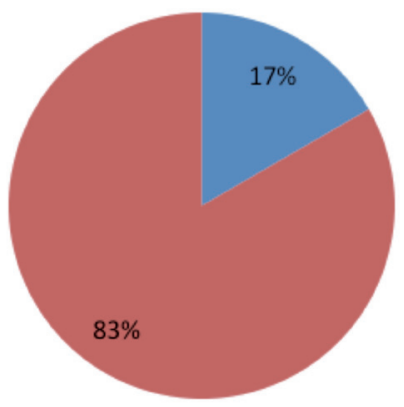

Fuente: la autora

Las respuestas a la pregunta 8, dan cuenta del favoritismo que sienten los estudiantes por la asignatura Evaluación de aprendizaje en la que se evalúan las exploraciones puestas en escena durante la asignatura Teorías cognitivas el semestre pasado (fueron los mismos estudiantes), en el que se decidió no aplicar la encuesta para tomar distancia del proceso evaluativo al que se vieron enfrentados los estudiante. El 83\% le dan la máxima calificación. Con respecto a la pregunta 7 , posiblemente el $72 \%$ de los estudiantes que asignaron la máxima calificación a la asignatura que más les permite avanzar, estén haciendo referencia a Evaluación del aprendizaje (si comparamos los resultados a la pregunta 8). Que los estudiantes señalen a Evaluación del aprendizaje, una asignatura $100 \%$ teórica como la que más les permite avanzar en su proceso de aprendizaje y la que más los emociona, de acuerdo con las respuestas a la pregunta 6, da cuenta de la conexión emoción-razón que hemos venido defendido por su valor educativo motivacional si nos atenemos a Carretié cuando sostiene la presencia de redes neurales subyacentes a la emoción que incluyen conexiones directas con los sistemas motivacionales primarios.

Figura 35. Pregunta 9. Califique de 1 a 5 las actividades que más le emocionan. Conversatorio, clase tradicional, trabajo individual o trabajo colectivo

$\begin{array}{ll}\text { - Convesatorio } & \text { Trabajo individual } \\ \text { Clase tradicional } & \text { Trabajo colectivo }\end{array}$

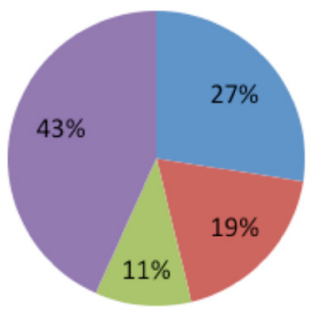

Fuente: la autora 
Finalmente, la última pregunta de la encuesta (la pregunta 10), permite a cada estudiante, expresar con sus propias palabras las diferencias que encuentra específicamente entre las "prácticas pedagógicas" de la asignatura Evaluación del aprendizaje y las demás asignaturas. Las respuestas podrían resumirse en las siguientes expresiones:

La diferencia son las estrategias de aprendizaje y la participación de los estudiantes. La forma de enseñar de los docentes y la metodología de aprender. Si hay diferencias, los ejemplos que efectúa la maestra en clase, ya que hace que se asimilen mejor las temáticas. La diferencia a las otras es que es más práctica, la metodología es buena. Las otras clases se tornan monótonas y largas porque no hay una "confianza" no un buen manejo de las clases. La mayoría de los profesores hablan mucho...los temas son muy intrigantes y emocionantes. Todo. La profesora es excelente, divertida, la clase igual. Esta clase aprende a incluir la opinión de los demás corrigiendo y reforzando el conocimiento. Es más dinámica y practica y a pesar de que es teórica, aprendo de manera, es real que las demás. Dinamismo, conversación y análisis. Es práctica para la vida cotidiana y profesional. La profesora hace las clases dinámicas a pesar de que es totalmente teórica. Se preocupa por sus estudiantes. 


\section{Conclusiones y Recomendaciones}

En un mundo evidentemente contingente, entrenar para la permanencia es un engaño al que se someten los estudiantes. Reivindicar el protagonismo de lo emocional en un mundo que se deshumaniza cada vez más por concepto de la mera razón resulta perentorio. Lejos de interesarnos por las implicaciones de la emoción o de la razón de manera individual, nos centramos en el poder de su conexión.

La coexistencia física y mental de varias culturas, obliga repensar los fines educativos y la adopción de estrategias integradoras y legitimadoras (Maturana) ante la diversidad. Continuar reprimiendo la emoción y dividiendo lo que por naturaleza está unido, es un pecado capital que terminan pagando los estudiantes y la sociedad a precios muy altos. Decir que las emociones se gestan en el inconsciente y nada tienen que ver con la voluntad, que solo son "sentidas" que nunca son "pensadas", son equivocaciones propias de los currículos que ahorran pensar y evitan sentir, cuando no es que parcelan el mundo y hacen de los estudiantes agentes acríticos y mecanicistas.

Si tenemos varios sistemas cerebrales de acuerdo con MacLean, si los utilizamos de diferentes formas, de acuerdo con Gardner, es necesario adelantar otros discursos y prácticas pedagógicas de frente a la multiplicidad humana y cognitiva, que conecten la emoción con la razón, camino del cambio. Ignorar la multiplicidad de planteamientos y avances científicos sobre el protagonismo de las emociones y especialmente su conexión con la razón, favorece la educación estacionaria, que educa para un mundo que ya no existe, o por lo menos no es el que viven los jóvenes actuales.

No basta con que nos preocupemos por las emociones, existen emociones positivas como el amor que contribuyen a la constitución y desarrollo de la capacidad de las personas para tomar parte de la vida en sociedad, para la justicia y la felicidad como eudaimonía. Las emociones positivas y su conexión con la razón, son una herramienta que garantiza la condición de agentes de justicia. Si las decisiones racionales están poderosamente influenciadas por las emociones (Maturana), haría repensar la educación en consecuencia. Continuar educando estudiantes actuales con estrategias del siglo pasado, hace de la educación un espacio cada vez más anacrónico y descontextualizado profundizando la descomposición social y dejando a los estudiantes sin más valor que el del dinero y sin más felicidad que la a corto plazo que ofrece el consumismo. La educación es la mejor oportunidad para aportar a la trasformación del ser humano y a la cohesión social.

Si el mundo no es uno ni la verdad es una como lo pretendía Platón, si no hay una sola forma de enseñar y de aprender como lo propuso Comenio por qué continuar entrenando en el universalismo y utilizando estrategias desuetas que ignoran las necesidades actuales de los estudiantes y desmembran cada vez más la sociedad?

La educación y la sociedad mantienen una continua batalla entre lo apolíneo (representado por la teoría) y lo dionisiaco (el peligro que representan las emociones de todas las clases) 
buscar su interacción sería la clave.

¿Cómo mantener la dinámica sin que se desborde de uno de los extremos?, se requiere que el profesor esté atento a los cambios, sea flexible y con capacidad de entregar su trabajo por los demás, con el fin de mantener el justo medio de la interacción.

¿Qué hacer con los agelastos? Probablemente no mucho, pero se puede hacer con los niños y adolescentes y esperar resultados en el futuro.

No solo estamos habitados de emociones positivas, hay emociones que son básicamente negativas. Con Damasio sabemos que miedo, ira, alegría, tristeza, sorpresa y asco, son emociones básicas de fácil identificación y que además, compartimos con algunas especies no humanas. Estas pueden o no pasar por la razón. Básicamente son adaptativas, si no le dan asco se comen los venenos, todo lo huelen primero. Son positivas y necesarias para la convivencia. Las emociones derivadas o secundarias solo existen con intervención de la razón como la envidia, la vergüenza, el egoísmo y la envidia. Nadie se ufana de sentir envidia, tortura a la gente, no los deja vivir tranquilos. Estas emociones son para la vida social. Si el ser humano tiene envidia hace la mitad y sufre la otra mitad, de ahí la necesidad de conectar la razón con la emoción, para controlar todo aquello que nos hace violentos e infelices y no nos permite construir con nosotros mismos y con los demás.

El currículo, lejos de enfocarse únicamente en entrenar para pensar y para actuar, necesita, además, incluir la afectividad para formar al ser atento a las realidades sociales y culturales actuales y a su posterior intervención. Trascender juntos la muralla reduccionista de la racionalidad instrumental, sería la clave.

El papel del educador no se limita a aplicar la norma, sino, que debe ser, además, un artista, un actor, un mago, un constructor de nuevas prácticas pedagógicas que democraticen la educación, las culturas y las sociedades actuales y las futuras, siempre con el objetivo de ser en la medida que el otro es, no al margen del otro. Para ello, es necesario adelantar gestiones que formulen currículos y planes de estudio que apunten a la formación integral. 


\section{Bibliografía}

-Aristóteles. (1988). Poética. Bogotá: Ed. Gredos

-Austin, J. L. (1971). Cómo hacer cosas con palabras: palabras y acciones. Copilado por U.O. Urmson. Barcelona: Paidós.

-Bauman, Z. (2002). Modernidad líquida. México: fondo de cultura económica.

-Boal, A. (2000). Theater of the oppressed. London: Pluto Press

-Boal, A. (2006). The Aesthetics of the Oppressed. London: Pluto Press

-Carretié. A. L. (2011). Anatomía de la mente. Emoción, cognición y cerebro. Madrid: ediciones pirámide.

-Comenio, J. A. (1988). Didática Magna. México: Porrúa. Colección Sepan Cuántos.

-Comenio, J. A. (1905). The Laberynt of the world and the paradise of the heart (Count Lutzow, Ed. y Trad.). Londres: J. M. Dent.

-Comenius, J. A. (1992). Pampedia. Madrid: Universidad Nacional de Educación a Distancia. Colección AA, 57.

-Comenio, J. A. (1993). El mundo sensible en imágenes. (A. Hernández, Trad.). México: CONACYT-Miguel Ángel Porrúa

-Damasio, A. (1994). Descartes' Error: Emotion, Reason and the Human Brain. Pac Macmillan.

-Damasio, A. (2005). En busca de Spinoza. Editorial Crítica.

-Damasio, A. (2010). Y el cerebro creó al hombre. Barcelona: Editorial Planeta

-Descartes, R. (2011). Discurso del método. Trad. de Cirilo Flórez Miguel. Obra completa. Biblioteca de Grandes Pensadores. Madrid: Editorial Gredos.

-Deslauriers, J. P. (2004). Investigación cualitativa, guía práctica. Pereira: Papiro.

-Dewey, J. (1934). El arte como experiencia. Barcelona: Ediciones Paidós Ibérica, S, A.

-Feliu, G. E. (1982). Los lenguajes de la publicidad. Tesis doctoral. Universidad de Alicante. España.

-Freire, P. (1970). Pedagogía del oprimido. Uruguay: siglo XXI Editores s. a. de c. v.

-Freire, P. (1997). Pedagogía de la autonomía. España: siglo XXI Editores s. a.

-Gardner, Howard. (1983). "Frames of Mind: The Theory of Multiple Intelligences." New York: Basic Books.

-Gardner, Howard. (1993). "Multiple Intelligences: The Theory Into Practice." New York: Basic Books. 
-Gardner, Howard. (1999). "Intelligence Reframed: Multiple Intelligences for the $21^{\text {st }}$ Century." New York: Basic Books

-Gardner, Howard. (1999). "Intelligence Reframed: Multiple Intelligences for the $21^{\text {st }}$.

-Hall, C. (1978). Fundamentos de la psicología de Jung. Buenos Aires: Psique.

-Lakoff, G \& johnson, M. (2009) Metáforas de la Vida Cotidiana. Anaya.

-Lipovetsky G. (2007). La felicidad paradójica: Ensayo sobre la sociedad de hiperconsumo. Anagrama.

-Lipovetsky G. (1986). La era del vacío: Ensayo sobre el individualismo contemporáneo. Barcelona: Anagrama.

-Lipovetsky G. (2006). Ensayos. Los tiempos hipermodernos. Barcelona: Anagrama.

-Maturana, H. (1990). Emociones y Lenguaje en educación y Política. España: Dolmen Ediciones.

-Maquilón. S, Javier (2003). Diseño y evaluación del diseño de un programa de intervención para la mejora de las habilidades de aprendizaje de los estudiantes universitarios. Tesis doctoral. Murcia. España.

-MacLean P.D. (1973). A triune concept of the brain and behavior. In. TJ Boag, D Campbell (Eds), The Hincks Memorial Lectures (pp 6-66), Toronto: University of Toronto Press.

-MacLean P.D. (1988). Evolution of audiovocal communication as reflected by the therapsidmammalian transition and the limbic thalamocingulate division. In JD Newman. New York: Plenum Press.

-MacLean PD (1990) The Triune Brain in Evolution: Role in Paleocerebral Functions. New York: Plenum Press.

-MacLean P.D. (1993). Cerebral evolution of emotion. In M Lewis, JM Haviland. New York: Guilford Press.

-MacLean P.D. Newman J. D (1988). Role of midline frontolimbic cortex in production of the isolation cell of squirrel monkeys. Brain Res. 450:111-123.

-MacLean, P. D. (1990). The triune brain evolution. New York: Plenun Press.

-MacLean, P.D. (1991). Neofrontocerebellar evolution in regard to computation and prediction: Some fractal aspects of microgenesis. In: Hanlon RE, ed. Cognitive microgenesis: A neuropsychological perspective. New York: Springer-Verlag.

-MacLean, P.D. (1996). Limbic system. In: Beaumont JG, Kenealy PA, Rogers JC, eds. The Blackwell dictionary of neuropsychology. Oxford: Basil Blackwell.

-Mithen, S. (1998). Arqueología de la mente. Orígenes del arte, de la religión y de la ciencia. Barcelona: Cultura libre.

-Montessori, M. (1912). El método Montessori.

-Nietzsche, F. (1990). Sobre verdad y mentira en sentido extra moral. Technos. 
-Nietzsche, F. (2005). Así habló Zaratustra. Edición de José Rafael Hernández Arias. Madrid: Valdemar.

-Nussbaum, M. (1997). Justicia poética: la imaginación literaria y la vida pública. Traducción de Carlos Gardini Barcelona: Andrés Bello.

-Nussbaum, M. (2010). Sin fines de lucro. Por qué la democracia necesita de las humanidades. Buenos Aires/Madrid, Katz editores.

-Ogando, D. B. (2010). El cine como herramienta docente en bioética y tanatología. Tesis doctoral. Universidad Complutense de Madrid. Facultad de Medicina. Departamento de Medicina Preventiva, Salud Pública e Historia de la Ciencia.

-Platón. (2009). La República. Colombia: Atenea.

-Reyes, G. (1996). El abecé de la pragmática. Madrid: Arco libros.

-Serna, J. (2004). Filosofía, literatura y giro lingüístico. Bogotá: Siglo del hombre editores.

-Serna, J. (2007). Giro lingüístico, Ontologías alternativas: Aperturas de mundo desde el giro lingüístico. Barcelona: Anthopos.

-Silva, A. (2004). Imaginarios Urbanos: hacia el desarrollo de un urbanismo desde los ciudadanos. Metodología de trabajo. Bogotá: Convenio Andrés Bello

-Skinner. B. (1987). Sobre el conductismo. Barcelona: Martínez Roca.

-Strawson, P. F. (1995). Libertad y resentimiento. Barcelona: Paidós.

-Vigotski, L. (2008). Pensamiento y lenguaje. México. Ediciones Quinto Sol.

- Whorf, B. (1971). Lenguaje, pensamiento y realidad. Selección de escritos. Trad. De José M. Pomares. Barcelona: Barral.

-Morgan, J. (2003). El cerebro en evolución. Barcelona: Ariel

\section{Recursos electrónicos}

- Aristóteles. De la Interpretación. Resumen mínimo de su pensamiento. Ensayo de Javier Echegoyen Olleta, disponible en http://www.e-torredebabel.com/Historia-de-la-filosofia/ Minima/Aristoteles.

- Aristóteles, Retórica, Gredos, Madrid, 1992.

http://www.psicologosorganizacionales.net/2012/02/neuromarketing-como-llegar-la-mentedel.html

- Damasio. http://alimentaciondietaynutricion.com/wp-content/uploads/2012/08/ Educaci\%C3\%B3n-Emocional-Entrevista-a-Antonio-Damasio.pdf.https://sites.google.com/ site/cerebrohumanoycalculoracional/algunos-nombres/paul-maclean-cerebrotriuno/paulmaclean

- Comenio, J. A. Didáctica Magna. Extraída el 12 de mayo de 2012 de: http://es.scribd.com/ doc/17326162/Amos-Comenio-j-Didactica-Magna. 
- Strawson, P. F. Libertad y Resentimiento. Texto 4. Extraído el 4 de junio de 2012 de: http:// esepulveda.cl.tripod.com/libertad_y_resentimiento.htm

-MacLean, P. El encuentro de las mentes. Extraído el 20 de junio de 2012 desde:

http://www.elhumanoinfinito.net/descargas/El\%20encuentro\%20de\%20las\%20mentes.pdf

-LeDoux, J. The Emotional Brain, Fear, and the Amygdala. Extraído el 1 de Julio de 2012 de http://www. ekmaninternational.com/media/4634/fearbrain\%20amygdala\%20joe\%20ledoux.pdf

-http://books.google.com.co

-http://www.philosophia.cl

-https://docs.google.com

-http://coral.ufsm.br

-http://es.wikipedia.org

-http://www.tebeosfera.com

-http://www.eduardpunset.es

\section{Tesis doctorales}

- Belli, Simone (2009). Emociones y Lenguaje. Tesis doctoral. Universidad Autónoma de Barcelona. España. Extraída el 8 de octubre de 2013 de http://www.academia.edu/332275/Emociones_y_ Lenguaje_Tesis_doctoral_entera

- Feliu, G. E. (1982). Los lenguajes de la publicidad. Tesis doctoral. Unversidad de Alicante. España. Extraído el 5 de febrero de 2013 de:http://www.google.com.co/ url sa $=t \& r c t=j \& q=\& e s r c=s \&$ source $=w e b \& c d=1 \& s q i=2 \& v e d=0 C C w Q F j A A \& u r l=h t t p \% 3 A \% 2 F \% 2 F r u a$. 


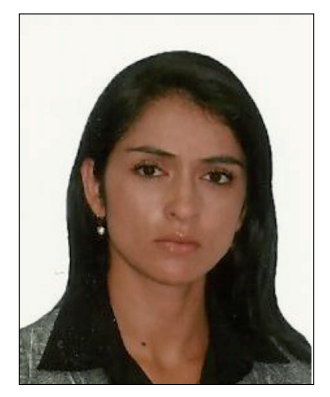

Consuelo Orozco Giraldo, (Santa Rosa de Cabal, Risaralda, Colombia, 1978). Doctora en Ciencias de la Educación, Universidad Tecnológica de Pereira; Magíster en Comunicación Educativa por la misma Universidad. Licenciada en Pedagogía Infantil, Universidad del Tolima. Profesora asistente de la Facultad de Educación de la Universidad Tecnológica de Pereira.

Autora de los libros: Peligro inminente. Un falso estereotipo (2014); De la educación a la lengua. Los fines y los medios (2014).

Ha recibido los reconocimientos: a la labor como docente catedrática de la modalidad de educación a distancia de la Universidad del Tolima, 2013. Tesis de doctorado laureada, Universidad Tecnológica de Pereira, 2015. Graduado destacado, categoría AcademiaInvestigación, Universidad del Tolima, 2015. Ha sido par evaluadora del MEN, investigadora y profesora invitada en España por la Universidad de Sevilla y en los Estados Unidos por la Universidad de Harvard.

Pertenece al grupo de investigación Filosofía posmetafísica.

consuelorozco@utp.edu.co

La Editorial de la Universidad Tecnológica de Pereira tiene como política la divulgación del saber científico, técnico y humanístico para fomentar la cultura escrita a través de libros y revistas científicas especializadas.

Las colecciones de este proyecto son: Trabajos de Investigación, Ensayo, Textos Académicos y Tesis Laureadas.

Este libro pertenece a la Colección de Tesis Laureadas. 
Con estrategias sometidas al modelo de racionalidad instrumental, al margen de la emoción, la academia se hace cada vez más anacrónica. Si el ser humano además de razón, alberga emoción, en concordancia con los avances neurocientíficos de los últimos años, la academia no puede menos que actualizar sus métodos en esa dirección. A la par que la racionalidad instrumental gobierna la academia, el consumo emocional desenfrenado se convierte en el signo de nuestros tiempos. Lejos de rendir culto a las dicotomías, nos preguntamos por las circunstancias socioculturales a partir de las cuales los términos razón y emoción se consolidan en Occidente como antagonistas. Reivindicar el protagonismo de la conexión emoción-razón es el reto que nos compete, y abordarlo en el campo educativo es la urgencia del presente. 